\title{
Water-Quality Assessment of the White River Basin, Indiana: Analysis of Selected Information on Nutrients, 1980-92
}

By JEFFREY D. MARTIN, CHARLES G. CRAWFORD, JEFFREY W. FREY, AND GLENN A. HODGKINS

NATIONAL WATER-QUALITY ASSESSMENT PROGRAM

U.S. Geological Survey

Water-Resources Investigations Report 96-4192

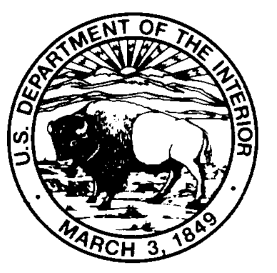

Indianapolis, Indiana 1996 


\title{
U.S. DEPARTMENT OF THE INTERIOR BRUCE BABBITT, Secretary
}

\author{
U.S. GEOLOGICAL SURVEY \\ Gordon P. Eaton, Director
}

For additional information, write to:

District Chief

U.S. Geological Survey

Water Resources Division

5957 Lakeside Boulevard

Indianapolis, IN 46278-1996
Copies of this report can be purchased from:

U.S. Geological Survey

Branch of Information Services

Box 25286

Denver, CO 80225-0286

Information regarding the National Water-Quality Assessment (NAWQA) Program is available on the Internet via the World Wide Web. You may connect to the NAWQA Home Page using the Universal Resource Locator (URL) at: 


\section{FOREWORD}

The mission of the U.S. Geological Survey (USGS) is to assess the quantity and quality of the earth resources of the Nation and to provide information that will assist resource managers and policymakers at Federal, State, and local levels in making sound decisions. Assessment of water-quality conditions and trends is an important part of this overall mission.

One of the greatest challenges faced by waterresources scientists is acquiring reliable information that will guide the use and protection of the Nation's water resources. That challenge is being addressed by Federal, State, interstate, and local water-resource agencies and by many academic institutions. These organizations are collecting water-quality data for a host of purposes that include: compliance with permits and water-supply standards; development of remediation plans for a specific contamination problem; operational decisions on industrial, wastewater, or water-supply facilities; and research on factors that affect water quality. An additional need for waterquality information is to provide a basis on which regional and national-level policy decisions can be based. Wise decisions must be based on sound information. As a society we need to know whether certain types of water-quality problems are isolated or ubiquitous, whether there are significant differences in conditions among regions, whether the conditions are changing over time, and why these conditions change from place to place and over time. The information can be used to help determine the efficacy of existing water-quality policies and to help analysts determine the need for and likely consequences of new policies.

To address these needs, the Congress appropriated funds in 1986 for the USGS to begin a pilot program in seven project areas to develop and refine the National Water-Quality Assessment (NAWQA) Program. In 1991, the USGS began full implementation of the program. The NAWQA Program builds upon an existing base of water-quality studies of the USGS, as well as those of other Federal, State, and local agencies. The objectives of the NAWQA Program are to:

-Describe current water-quality conditions for a large part of the Nation's freshwater streams, rivers, and aquifers.
-Describe how water quality is changing over -Improve understanding of the primary natural and human factors that affect water-quality conditions.

This information will help support the development and evaluation of management, regulatory, and monitoring decisions by other Federal, State, and local agencies to protect, use, and enhance water resources.

The goals of the NAWQA Program are being achieved through ongoing and proposed investigations of 60 of the Nation's most important river basins and aquifer systems, which are referred to as study units. These study units are distributed throughout the Nation and cover a diversity of hydrogeologic settings. More than two-thirds of the Nation's freshwater use occurs within the 60 study units and more than two-thirds of the people served by public water-supply systems live within their boundaries.

National synthesis of data analysis, based on aggregation of comparable information obtained from the study units, is a major component of the program. This effort focuses on selected water-quality topics using nationally consistent information. Comparative studies will explain differences and similarities in observed water-quality conditions among study areas and will identify changes and trends and their causes. The first topics addressed by the national synthesis are pesticides, nutrients, volatile organic compounds, and aquatic biology. Discussions on these and other waterquality topics will be published in periodic summaries of the quality of the Nation's ground and surface water as the information becomes available.

This report is an element of the comprehensive body of information developed as part of the NAWQA Program. The program depends heavily on the advice, cooperation, and information from many Federal, State, interstate, Tribal, and local agencies and the public. The assistance and suggestions of all are greatly appreciated.
Robert M. Hirsch

Chief Hydrologist 


\section{CONTENTS}

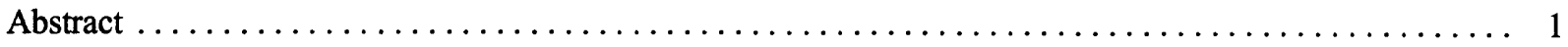

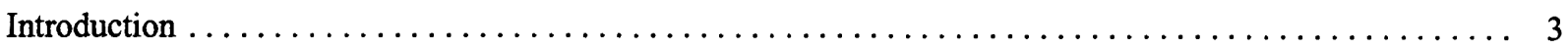

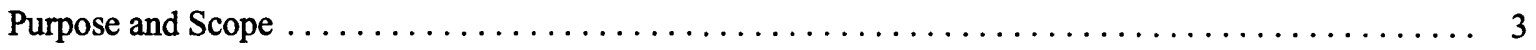

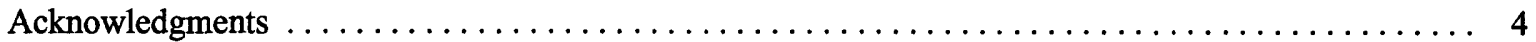

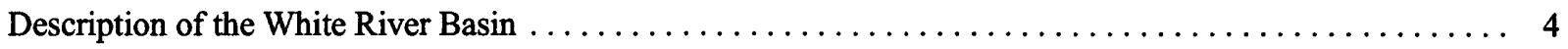

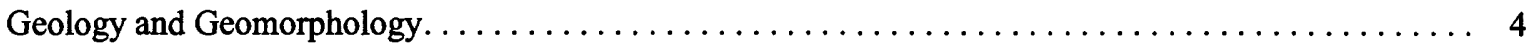

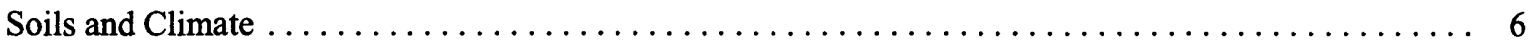

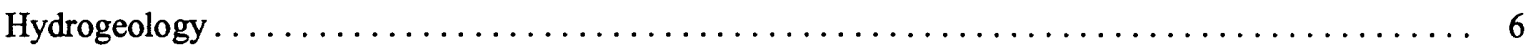

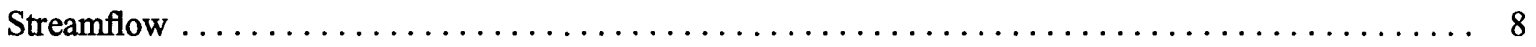

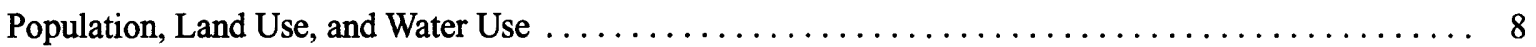

Agricultural Practices . . . . . . . . . . . . . . . . . . . . . . . . 9

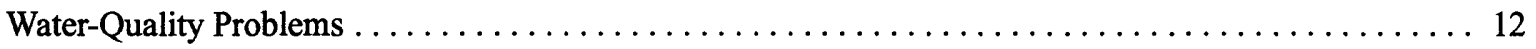

Hydrogeomorphic Regions of the White River Basin . . . . . . . . . . . . . . . . . . 14

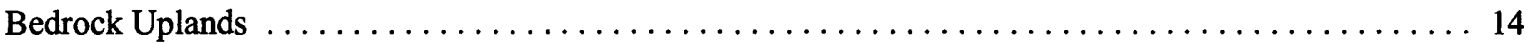

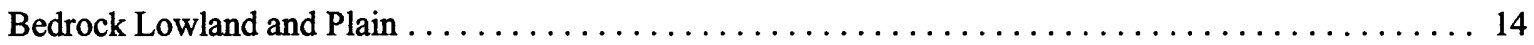

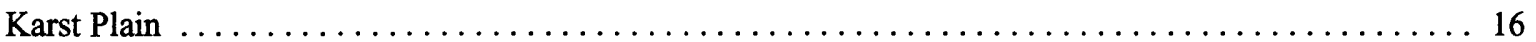

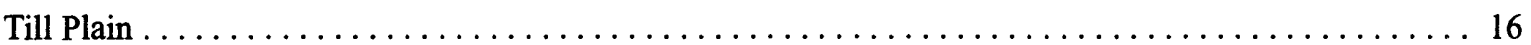

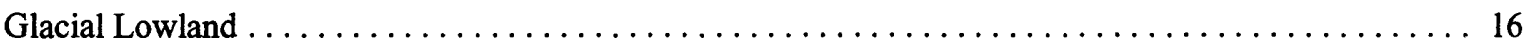

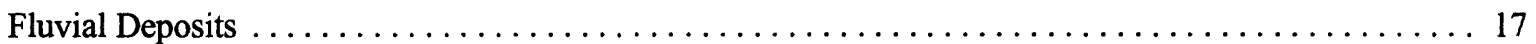

Analysis of Water-Quality Data . . . . . . . . . . . . . . . . . . . . . . . . 17

Sources, Selection, and Methods of Analysis of Water-Quality Data . . . . . . . . . . . . 18

Sources of Data Used in Assessing Water Quality . . . . . . . . . . . . . . . . 18

Field and Laboratory Methods. . . . . . . . . . . . . . . . . . . . . . . . 19

Data Compilation, Screening, and Methods of Analysis . . . . . . . . . . . . . . . 20

Spatial, Temporal, and Hydrologic Characteristics of Water-Quality Data . . . . . . . . . . . . 25

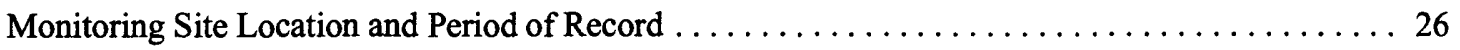

Distribution of Surface-Water Samples by Season and Streamflow . . . . . . . . . . . . 31

Distribution of Ground-Water Samples by Aquifer Type, Hydrogeomorphic Region, and

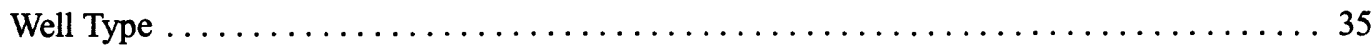

Relation of Nutrient Concentrations and Loads to Natural and Human Factors . . . . . . . . . . 37

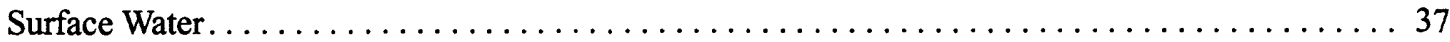

Relation of Nutrient Concentrations to Land Use . . . . . . . . . . . . . . . 37

Relation of Nutrient Concentrations to Season and Streamflow . . . . . . . . . . . 42

Time Trends in Nutrient Concentrations . . . . . . . . . . . . . . . . . . . . . 48

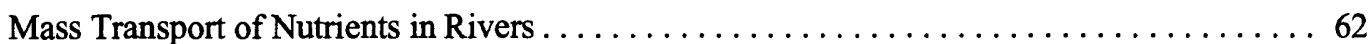

Point and Nonpoint Sources of Nutrients $\ldots \ldots \ldots \ldots \ldots \ldots \ldots \ldots \ldots \ldots \ldots \ldots \ldots \ldots$

River Loads and Yields . . . . . . . . . . . . . . . . . . . . . . . 64

Relation of Nutrient Concentrations in Base Flow to Hydrogeomorphic Region . . . . . . . . . 72

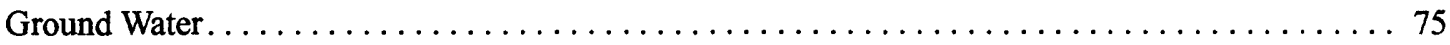

Relation of Nutrient Concentrations to Aquifer Type and Well Depth . . . . . . . . . . 75

Relation of Nutrient Concentrations to Well Type and Season . . . . . . . . . . . . . . . 79 


\section{CONTENTS—Continued}

Conceptual Model of the Factors Affecting Nutrients in the White River Basin . . . . . . . . . . . . 79

Implications of the Assessment for Data Collection and Analysis $\ldots \ldots \ldots \ldots \ldots \ldots \ldots \ldots \ldots \ldots$

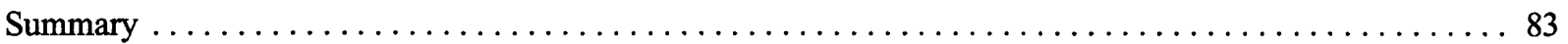

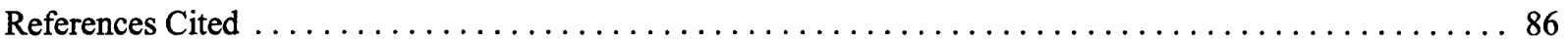

\section{ILLUSTRATIONS}

1-3. Maps showing:

1. Location of the White River Basin in Indiana $\ldots \ldots \ldots \ldots \ldots \ldots \ldots \ldots \ldots \ldots \ldots$

2. Geomorphic units in the White River Basin, Indiana $\ldots \ldots \ldots \ldots \ldots \ldots \ldots \ldots \ldots \ldots$

3. Hydrogeomorphic regions used to investigate water quality in the White River Basin, Indiana . . . . . . . . . . . . . . . . . . . . . 15

4. Example boxplot showing central tendency and variability of water-quality concentrations $\ldots \ldots 23$

5-6. Maps showing:

5. Location of selected surface-water-quality monitoring sites, streamflow-gaging stations, and precipitation-quality monitoring sites in and near the White River Basin, Indiana,

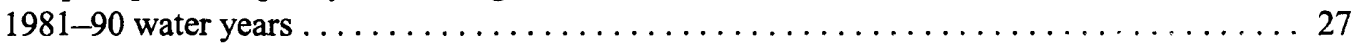

6. Mean daily discharge from selected municipal sewage-treatment plants in the White

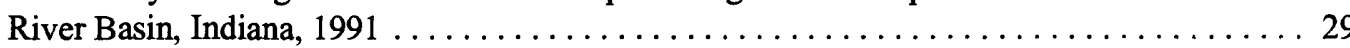

7. Graphs showing period of record for nutrient samples collected at selected surface-water-quality monitoring sites in the White River Basin, Indiana, 1981-90 water years $\ldots \ldots \ldots \ldots \ldots \ldots \ldots$

8-9. Maps showing:

8. Location of small-stream, base-flow water-quality sampling sites in the White River

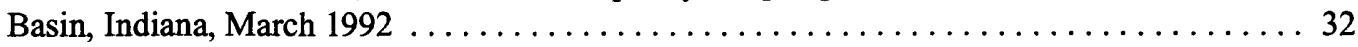

9. Location of ground-water-quality sampling sites in the White River Basin, Indiana,

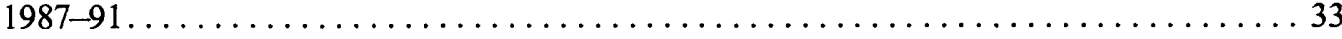

10-19. Graphs showing:

10. Number of nutrient samples by season and by percentile of streamflow at selected surface-water-quality monitoring sites in the White River Basin, Indiana, 1981-90 water

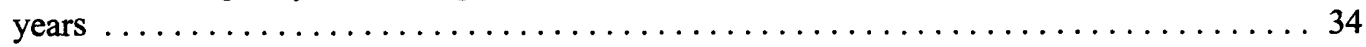

11. Number of wells by aquifer type and well type, White River Basin, Indiana, 1987-91 . . . 36

12. Nutrient concentrations at surface-water-quality monitoring sites in the White River

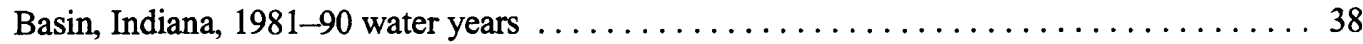

13. Median concentrations of nutrients at national reference sites, $1980-89$ water years . . . . 41

14. Seasonal variations in nutrient concentrations at selected surface-water-quality monitoring sites in the White River Basin, Indiana, 1981-90 water years. . . . . . . . . 44

15. Relation of nutrient concentrations to streamflow at selected surface-water-quality monitoring sites in the White River Basin, Indiana, 1981-90 water years. . . . . . . . . . 46

16. Concentrations of total ammonia at surface-water-quality monitoring sites in the White

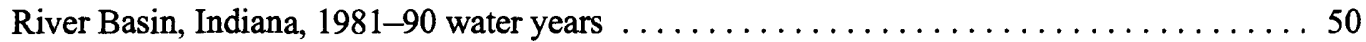

17. Concentrations of total nitrite plus nitrate at surface-water-quality monitoring sites in the White River Basin, Indiana, $1981-90$ water years $\ldots \ldots \ldots \ldots \ldots \ldots \ldots \ldots \ldots \ldots \ldots \ldots \ldots \ldots \ldots \ldots$

18. Concentrations of total nitrogen at surface-water quality-monitoring sites in the White River Basin, Indiana, $1981-90$ water years. . . . . . . . . . . . . . . . . 54

19. Concentrations of total phosphorus at surface-water-quality monitoring sites in the White River Basin, Indiana, 1981-90 water years 


\section{CONTENTS-Continued}

\section{ILLUSTRATIONS - CONTINUED}

20-21. Maps showing:

20. Time trends in nutrient concentrations at selected surface-water-quality monitoring sites in the White River Basin, Indiana, $1981-90$ water years . . . . . . . . . . . . . . . . . . 58

21. Mean annual loads of nutrients at selected surface-water-quality monitoring sites in the White River Basin, Indiana, $1981-90$ water years $\ldots \ldots \ldots \ldots \ldots \ldots \ldots \ldots \ldots$

22-27. Graphs showing:

22. Relations of nitrite plus nitrate concentration and load to streamflow at sites WR81 and EW79, 1981-90 water years

23. Mean annual nutrient yields at selected surface-water-quality monitoring sites in the White River Basin, Indiana, 1981-90 water years

24. Annual nutrient yields during dry and wet years at selected surface-water-quality monitoring sites in the White River Basin, Indiana $\ldots \ldots \ldots \ldots \ldots \ldots \ldots \ldots \ldots \ldots$

25. Nutrient concentrations during base flow in small streams in different hydrogeomorphic regions in the White River Basin, Indiana, March $1992 \ldots \ldots \ldots \ldots \ldots \ldots \ldots \ldots \ldots$

26. Nutrient concentrations in wells in different types of aquifers in the White River Basin,

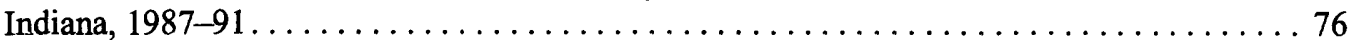

27. Relation of nutrient concentrations to well depth in the White River Basin, Indiana, $1987-91$

\section{TABLES}

1. Description of selected Indiana Department of Environmental Management surface-waterquality monitoring sites in the White River Basin, Indiana, $1981-90$ water years . . . . . . . . 28

2. Summary of exploratory trend analysis of concentrations of total ammonia at surface-waterquality monitoring sites in the White River Basin, Indiana, $1981-90$ water years . . . . . . . . . 59

3. Summary of exploratory trend analysis of concentrations of total nitrite plus nitrate at surfacewater-quality monitoring sites in the White River Basin, Indiana, $1981-90$ water years . . . . . 60

4. Summary of exploratory trend analysis of concentrations of total phosphorus at surface-waterquality monitoring sites in the White River Basin, Indiana, $1981-90$ water years . . . . . . . . 61

5. Estimated inputs of nitrogen to selected drainage basins and mean annual nitrogen yields at selected surface-water-quality monitoring sites in the White River Basin, Indiana, 1981-90 water years

6. Estimated inputs of phosphorus to selected drainage basins and mean annual phosphorus yields at selected surface-water-quality monitoring sites in the White River Basin, Indiana, 1981-90

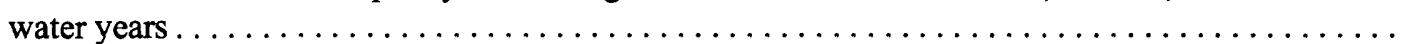

7. Ratio of nitrogen to phosphorus for inputs to selected drainage basins and for mean annual yields at selected surface-water-quality monitoring sites in the White River Basin, Indiana, 1981-90 water years 


\begin{tabular}{rll}
\hline \multicolumn{1}{c}{ Multiply } & \multicolumn{1}{c}{ By } & \multicolumn{1}{c}{ To Obtain } \\
acre & 0.4047 & hectare \\
bushel $(\mathrm{bu})$ & 0.03524 & cubic meter \\
cubic foot per second $\left(\mathrm{ft}^{3} / \mathrm{s}\right)$ & 0.02832 & cubic meter per second \\
foot $(\mathrm{ft})$ & 0.3048 & meter \\
cubic foot per second per square mile $\left.\left[\mathrm{ft}^{3} / \mathrm{s}\right) / \mathrm{mi}^{2}\right]$ & 0.01093 & cubic meter per second per square kilometer \\
foot per mile $(\mathrm{ft} / \mathrm{mi})$ & 0.1894 & meter per kilometer \\
gallon $(\mathrm{gal})$ & 3.785 & liter \\
inch $(\mathrm{in})$. & 25.4 & millimeter \\
inch per year $(\mathrm{in} / \mathrm{yr})$ & 25.4 & millimeter per year \\
$\mathrm{mile}(\mathrm{mi})$ & 1.609 & kilometer \\
million gallons per day $(\mathrm{Mgal} / \mathrm{d})$ & 0.04381 & cubic meter per second \\
pound per acre $(\mathrm{lb} / \mathrm{acre})$ & 1.121 & kilogram per hectare \\
pound per day $(\mathrm{lb} / \mathrm{d})$ & 453.6 & gram per day \\
square $\mathrm{mile}\left(\mathrm{mi}{ }^{2}\right)$ & 2.590 & square kilometer \\
ton & 0.9072 & megagram \\
ton per year $(\mathrm{ton} / \mathrm{yr})$ & 0.9072 & megagram per year \\
ton per square mile per year $\left[\left(\right.\right.$ ton $\left./ \mathrm{mi}{ }^{2}\right) / \mathrm{yr}$ & 0.3503 & megagram per square kilometer per year \\
\hline
\end{tabular}

Air temperature is given in degrees Fahrenheit $\left({ }^{\circ} \mathrm{F}\right)$, which may be converted to degrees Celsius $\left({ }^{\circ} \mathrm{C}\right)$ as follows:

$$
{ }^{\circ} \mathrm{C}=5 / 9\left({ }^{\circ} \mathrm{F}-32\right) \text {. }
$$

Water temperature is given in degrees Celsius $\left({ }^{\circ} \mathrm{C}\right)$, which may be converted to degrees Fahrenheit $\left({ }^{\circ} \mathrm{F}\right)$ as follows:

$$
{ }^{\circ} \mathrm{F}=1.8 \times{ }^{\circ} \mathrm{C}+32 \text {. }
$$

Sea level: In this report, "sea level" refers to the National Geodetic Vertical Datum of 1929 (NGVD of 1929)-a geodetic datum derived from a general adjustment of the first-order level nets of the United States and Canada, formerly called Sea Level Datum of 1929.

Water year: In U.S. Geological Survey reports, water year is the 12-month period, October 1 through September 30. The water year is designated by the calendar year in which it ends. Thus, the year ending September 30, 1990, is called the "1990 water year."

Water-quality units used in this report: Chemical concentrations and water temperature are given in metric units. Chemical concentration is given in milligrams per liter $(\mathrm{mg} / \mathrm{L})$. Milligrams per liter is a unit expressing the concentration of chemical constituents in solution as weight (milligrams) of solute per unit volume (liter) of water. For concentrations less than $7,000 \mathrm{mg} / \mathrm{L}$, the numerical value is the same as for concentrations in parts per million. 

Continued

The following abbreviations are used in this report:

\begin{tabular}{|c|c|}
\hline Abbreviation & Description \\
\hline IDEM & Indiana Department of Environmental Management \\
\hline USEPA & U.S. Environmental Protection Agency \\
\hline USGS & U.S. Geological Survey \\
\hline ANOVA & Analysis of variance \\
\hline GIRAS & Geographic Information Retrieval and Analysis System \\
\hline LOWESS & Locally weighted scatterplot smooth \\
\hline NADP & National Atmospheric Deposition Program \\
\hline NAWQA & National Water-Quality Assessment \\
\hline NPDES & National Pollutant Discharge Elimination System \\
\hline NWIS & National Water Information System \\
\hline SAS & Statistical Analysis System \\
\hline STORET & STOrage and RETrieval data base \\
\hline $\mathrm{N}$ & Nitrogen \\
\hline $\mathrm{TN}$ & Total nitrogen \\
\hline $\mathrm{NH}_{3}$ & Ammonia \\
\hline $\mathrm{NH}_{4}^{+}$ & Ammonium \\
\hline $\mathrm{NO}_{3}$ & Nitrate \\
\hline$P$ & Phosphorus \\
\hline PCB's & Polychlorinated biphenyls \\
\hline $\mathrm{TP}$ & Total phosphorus \\
\hline $\mathrm{pH}$ & Negative $\log$ (base-10) of the hydrogen ion activity, in moles per liter \\
\hline $\mathrm{mg} / \mathrm{L}$ & Milligram per liter \\
\hline $\mathrm{p}$ & Probability of obtaining a statistically significant test result by chance \\
\hline $\mathrm{pct} / \mathrm{yr}$ & Percent per year \\
\hline tau-b & Kendall correlation coefficient \\
\hline$<$ & Less than \\
\hline$\leq$ & Less than or equal \\
\hline+ & Increasing trend \\
\hline- & Decreasing trend \\
\hline
\end{tabular}




\title{
Water-Quality Assessment of the White River Basin, Indiana: Analysis of Selected Information on Nutrients, 1980-92
}

\author{
By Jeffrey D. Martin, Charles G. Crawford, Jeffrey W. Frey, and Glenn A. Hodgkins
}

\begin{abstract}
Water-quality data from 23 surfacewater-quality monitoring sites operated by the Indiana Department of Environmental Management and streamflow data from 11 U.S. Geological Survey streamflow-gaging stations in the White River Basin were analyzed to determine recent (1981-90 water years) water-quality conditions, trends, and river loads for ammonia, nitrate, total nitrogen, and total phosphorus. The White River Basin drains 11,349 square miles of central and south-central Indiana and is divided into two nearly equal subbasins - the East Fork White River and the White River upstream from its confluence with the East Fork (called the "west fork" of the White River by the State's water-management agencies).
\end{abstract}

Nutrient concentrations generally were higher in the more urbanized west fork than in the more rural east fork because of the much larger volumes of treated municipal sewage, combined-sewer overflows, and urban runoff discharged to the west fork. Concentrations of nutrients, especially ammonia and total phosphorus, were higher downstream from Muncie, Anderson, and Indianapolis than they were upstream from these cities. Nutrient concentrations decreased downstream from
Indianapolis in the White River and in the downstream reach of the East Fork White River because of dilution, nitrification, adsorption to stream-bottom sediments, and uptake by aquatic vegetation.

Seasonal variations in nutrient concentrations and the relations of nutrient concentrations to streamflow depended on the relative contributions of point and nonpoint sources of the nutrients. Total phosphorus increased with increasing streamflow at monitoring sites on the east fork but decreased with increasing streamflow at sites on the west fork. Increasing concentrations of phosphorus with increasing streamflow were consistent with nonpoint sources of phosphorus that wash off land surfaces, whereas decreasing concentrations of phosphorus with increasing streamflow were consistent with dilution of point sources of phosphorus. Median concentrations of total phosphorus were highest during summer and fall downstream from urban areas on the White River because streamflows that dilute point sources of phosphorus are lowest during summer and fall. Median concentrations of ammonia in the White River were highest in winter because of reduced biological uptake and nitrification of ammonia during cold temperatures. 
Concentrations of ammonia decreased during the 1981-90 water years at two monitoring sites on the White River downstream from Indianapolis. Improvements to the Indianapolis wastewater-treatment plants during 1982 were responsible for this beneficial change in water quality. Concentrations of ammonia, nitrate, and phosphorus increased during the 1981-90 water years at a monitoring site on the White River immediately upstream from Indianapolis, probably because of increased volumes of treated municipal sewage discharged from Carmel. Concentrations of total phosphorus increased during the 1981-90 water years at most monitoring sites on the White River upstream from Indianapolis, probably because of changes in the quantity or quality of treated municipal sewage discharged to the White River.

Commercial fertilizer is the largest source of nitrogen and phosphorus in the White River Basin. Inputs of nitrogen and phosphorus from municipal sewage to the White River at and upstream from Indianapolis were 4 to 10 times that at monitoring sites on the less populated East Fork White River. Atmospheric deposition contributed 11 to 19 percent of the total nitrogen input to the six large drainage basins selected for assessment of nutrient inputs. Mean annual nutrient loads near the mouth of the White River Basin were 1,200 tons per year of ammonia; 40,000 tons per year nitrate; 57,000 tons per year total nitrogen; and 2,900 tons per year total phosphorus. Approximately 2 percent of the total nitrogen load was ammonia, approximately 70 percent was nitrate, and approximately 28 percent was organic nitrogen.

Ammonia yields (loads divided by drainage area) increased downstream in the upstream reach of the White River, probably because of the cumulative effects of discharges from municipal sewage-treatment plants, combined-sewer overflows, and urban runoff in this reach. Phosphorus yields in the west fork were higher than those in the east fork because of the greater amounts of treated sewage and urban runoff in the west fork. Similar annual nitrate yields at the downstream monitoring sites on the east and west forks indicate that the effects of urban discharges of nitrate in the upstream reach of the White River were not discernible in the downstream reach, and that nonpoint sources of nitrate mask point sources of nitrate in terms of annual mass transport. The yield of nitrate downstream from Indianapolis (4.9 tons per square mile per year) was similar to the yield upstream from Indianapolis ( 4.8 tons per square mile per year) and is additional evidence to conclude that point sources of nitrate are relatively unimportant in the annual mass transport of nitrate in the White River Basin, even at the site most affected by point sources.

Ground-water-quality data from 101 wells were used to determine the effects of aquifer type, well depth, well type, and season on nutrient concentrations in ground water. Median concentrations of ammonia were highest ( 0.25 milligram per liter) in till aquifers (aquifers composed of buried sand and gravel lenses in till), probably because of biochemical reduction of nitrate to ammonia. Concentrations of nitrate in till aquifers were low, probably because till reduced the downward percolation of soil water containing nitrate and because reducing conditions (low concentrations of oxygen) in the till aquifer enabled denitrification and biochemical reduction. Median concentrations of nitrate were highest in karst aquifers, probably because macropores and sinkholes provided a direct connection of surface and ground water through preferential flow paths from the clayey mantle to the karst aquifer. 


\section{INTRODUCTION}

In 1991, The U.S. Geological Survey (USGS) began implementing a full-scale National WaterQuality Assessment (NAWQA) Program. The goals of the NAWQA Program are to describe current water-quality conditions and trends in our nation's rivers, streams, and ground water and to understand the natural and human factors that affect the conditions and trends in water quality (Hirsch and others, 1988, p. 1).

Study-unit investigations and national synthesis are the major design features of the NAWQA Program that allow water-quality information collected at local and regional scales to be integrated into a national description of water quality. Sixty study units include parts of most of the Nation's major river basins and account for approximately 60 to 70 percent of the Nation's water use and population served by public water supplies (Leahy and Wilber, 1991, p. 1). National synthesis will use comparative studies and other techniques to assess national water-quality conditions.

The major components of the study-unit investigations are (1) an assessment of existing water-quality data (retrospective analysis) to provide an initial understanding of water quality and to assist in developing a preliminary conceptual model of the hydrologic systems in the study unit, (2) an occurrence and distribution assessment to characterize the geographic and seasonal distribution of water quality, (3) longterm monitoring to determine water-quality trends, and (4) case studies of selected contaminants in local areas to investigate specific hydrologic processes or environmental effects.

Pesticides, nutrients, and suspended sediment were selected as the topics for the retrospective analysis and national synthesis. Pesticide data for the White River Basin are described in Carter and others (1995). Nutrient data are described in this report. Suspended-sediment data are described in Crawford and Mansue (1988).

\section{Purpose and Scope}

The purposes of this report are (1) to describe, analyze, and interpret the spatial and temporal patterns of nutrient concentrations and loads in the White River Basin through the use of existing data and (2) to describe and discuss a conceptual model of the factors that affect nutrient concentrations in surface and ground water in the basin.

Water-quality data from 23 surface-waterquality monitoring sites operated by the Indiana Department of Environmental Management (IDEM) and streamflow data from 11 U.S. Geological Survey streamflow-gaging stations were analyzed to determine recent (1981-90 water years) water-quality conditions, trends, loads, and yields. Seasonal and streamflow-related variations in the concentrations of ammonia, nitrate, total nitrogen, and total phosphorus were evaluated by comparing median concentrations among seasons and by examining correlations between concentrations and streamflow. Effects of urban, agricultural, and forested land use on water quality were examined by comparing concentrations and yields upstream from urban areas with those downstream from urban areas and by comparing concentrations and yields among monitoring sites that drain areas of different land uses. Tenyear time trends in nutrient concentrations were investigated by examining time-series plots of concentrations and by the use of two different tests for trend. Nutrient inputs from treated sewage, industrial discharges, atmospheric deposition, commercial fertilizer, and farm-animal manure were estimated for 6 large drainage basins, and mean annual river loads and yields were computed for 11 surface-water-quality monitoring sites.

Annual nutrient yields also were compared between wet and dry years.

Concentrations of nutrients in base-flow water samples from 48 small streams were analyzed to determine the effects of land use and hydrogeomorphic region on base-flow water quality by comparing median concentrations among regions. Ground-water samples from 101 wells were analyzed to determine the effects of aquifer type, well depth, well type, and season on nutrient 
concentrations in ground water. Median concentrations of nutrients were compared among till, outwash, bedrock, and karst aquifers and among community public water-supply wells, noncommunity public water-supply wells, domestic wells, and observation wells. Correlations between nutrient concentrations and well depth were calculated for all wells and for subsets by aquifer type. Seasonal variations in ground-water quality were assessed by comparing paired samples from 25 wells collected before and during the growing season.

A conceptual model of the natural and human factors affecting nutrient concentrations in surface and ground water in the White River Basin is described and discussed. Additional data needed to meet the goals of the NAWQA Program are described.

\section{Acknowledgments}

The authors thank the Indiana Department of Environmental Management for providing information on municipal and industrial return flows and for most of the surface-water-quality data used in this assessment; the Indiana Department of Natural Resources for providing water-use and water-withdrawal information; D.P. Franzmeier, Purdue University, for descriptions of Indiana soils; and R.W. Gann, Indiana Agricultural Statistics Service, for data reports on Indiana agriculture.

\section{DESCRIPTION OF THE WHITE RIVER BASIN}

The White River Basin drains 11,349 $\mathrm{mi}^{2}$ of central and south-central Indiana and joins the Wabash River in southwestern Indiana. The major part of the basin is divided into two nearly equal subbasins - the East Fork White River and the White River upstream from its confluence with the East Fork White River (called the "west fork" of the White River by the State's water management agencies). The East Fork White River drains $5,746 \mathrm{mi}^{2}$ and joins the White River at river mile 49.5 near Petersburg (fig. 1). The White River, upstream from its confluence with East Fork White River, drains $5,372 \mathrm{mi}^{2}$. Only 2 percent $\left(232 \mathrm{mi}^{2}\right)$ of the drainage area of the White River Basin is downstream from the confluence of the east and west forks.

The major tributaries (drainage areas greater than $500 \mathrm{mi}^{2}$ ) to the East Fork White River are the Driftwood River $\left(1,165 \mathrm{mi}^{2}\right)$, the Flatrock River $\left(542 \mathrm{mi}^{2}\right)$, the Muscatatuck River $\left(1,140 \mathrm{mi}^{2}\right)$, and Salt Creek $\left(636 \mathrm{mi}^{2}\right)$. The Driftwood River may be the shortest river in Indiana. Formed by the confluence of the Big Blue River and Sugar Creek, the Driftwood River flows only $15 \mathrm{mi}$ to its confluence with the Flatrock River, where they form the East Fork White River. The Big Blue River is considered the headwaters of the East Fork White River (Stewart and Nell, 1991, p. ix). The only major tributary to the White River, excluding the East Fork White River, is the Eel River (1,208 $\mathrm{mi}^{2}$ ) (Hoggatt, 1975). The reaches of the White River and the East Fork White River upstream from their confluence are referred to as the "west fork" and "east fork" in this report when comparing water quality between the subbasins or rivers.

\section{Geology and Geomorphology}

The White River Basin exhibits several different types of geologic features, including glaciated and nonglaciated areas; a karst area; and bedrock composed of sedimentary rocks underlain by a crystalline basement complex of granite, schist, and gneiss. The Illinois Basin is the major structural, geological feature in the region. Sedimentary rocks in the White River Basin dip to the southwest into the Illinois Basin at a rate of 10 to $30 \mathrm{ft} / \mathrm{mi}$. Surface and near-surface bedrock in the White River Basin is predominantly limestone, dolomite, sandstone, mudstone, shale, and coal. Glacial deposits cover approximately 60 percent of the basin, and only the south-central part has not been glaciated. Characteristics of the bedrock and unconsolidated deposits in the East Fork White River Basin are described in Fenelon and 


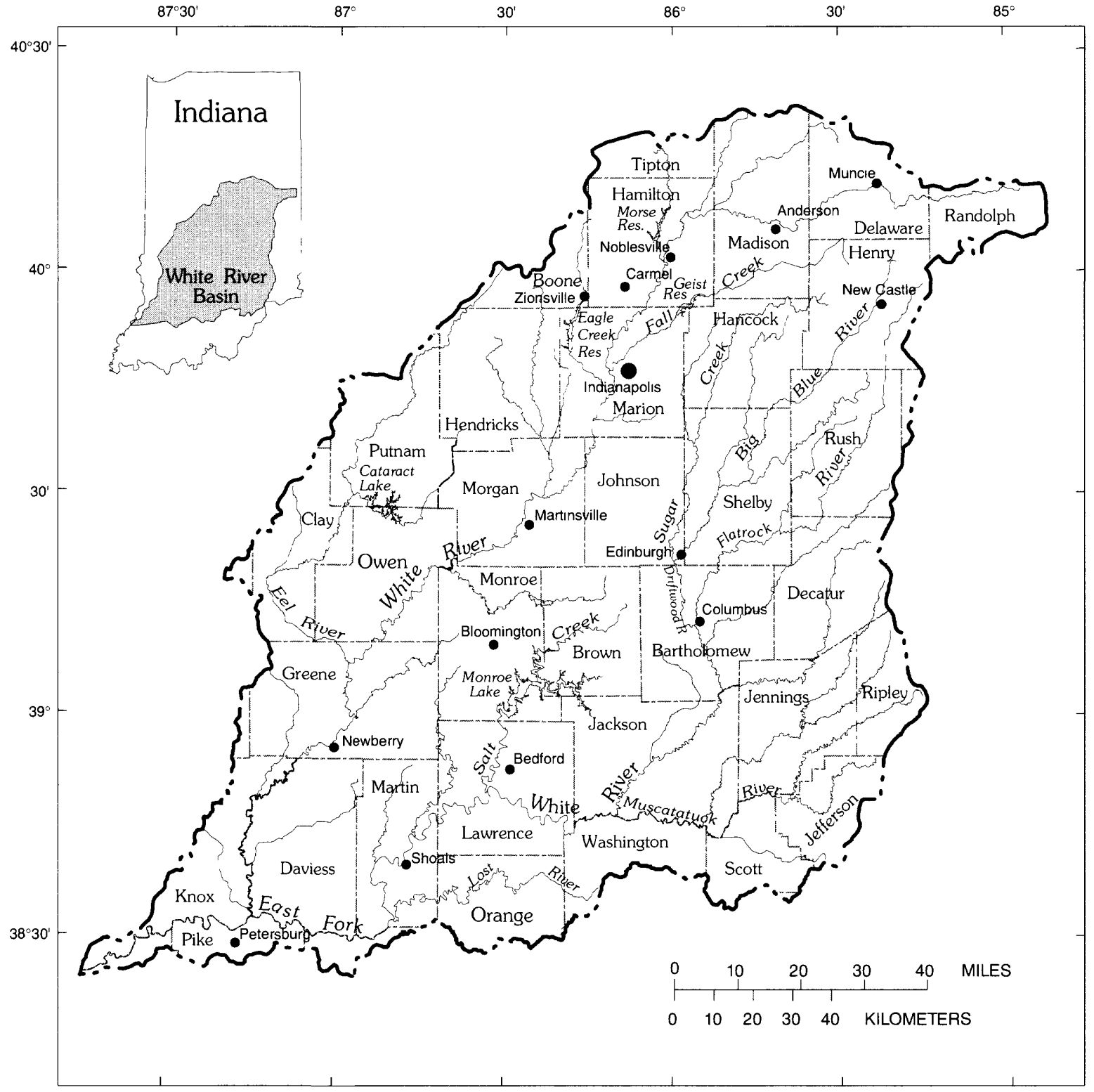

Base from U.S. Geological Survey digital data, 1:100,000, 1983

Albers Equal-Area projection
Standard parallels $29^{\circ} 30^{\prime}$ and $45^{\circ} 30^{\prime}$, central meridian $-86^{\circ}$

\section{EXPLANATION}

- White River Basin boundary

_..... County boundary

Figure 1. Location of the White River Basin in Indiana. 
Greeman (1994). Characteristics of the bedrock and unconsolidated deposits in the White River Basin, excluding the East Fork White River Basin, are described in Hoover and Durbin (1994).

The White River Basin contains seven geomorphic units originally defined by Malott (1922). Differences among these units are caused by bedrock geology and the extent of glaciation. The Tipton Till Plain is a flat to rolling glacial till plain that covers the northern half of the basin (fig. 2). The Wabash Lowland is in the southwestern part of the basin and is an area of broad, flat valleys and gently rolling plains. The Crawford Upland and the Norman Upland are westwardsloping, unglaciated upland areas with narrow ridge tops and steep slopes. The Mitchell Plain lies between the two upland units and is a karst plain with numerous sinkholes and solution features. The Scottsburg Lowland is east of the Norman Upland and is an area of low relief and extremely broad, flat valleys. The Muscatatuck Regional Slope is in the southeastern part of the basin and is a westward-sloping plain characterized by moderate relief and by bedrock outcrops in the stream channels.

\section{Soils and Climate}

The major suborders of soils in the White River Basin are the Udalfs (Gray-Brown Podzolic soils), the Aquolls (Humic Gley soils), and the Udults (Red-Yellow Podzolic soils) (Brady, 1974, plate 1). The Gray-Brown Podzolic soils are distributed widely throughout the basin. These soils have medium to high base content, clay accumulation at depth, and generally are farmed (Ulrich, 1966, p. 62). The well-drained GrayBrown Podzolic soils are moderately acidic and are moderately fertile, whereas the somewhat poorly drained Gray-Brown Podzolic soils are more extensive and more productive if adequately drained. The Humic Gley soils are along the major river valleys in the basin. These soils have a high base content and have developed in calcareous
Wisconsinan glacial deposits. The soils are seasonally saturated with water, have poor natural drainage, and contain 5 to 10 percent organic matter (Ulrich, 1966, p. 63). Most of the Humic Gley soils have been drained and farmed and produce high yields of corn and soybeans. The Red-Yellow Podzolic soils occur in the unglaciated, south-central part of the basin. These soils are acidic and thin and have low organic matter. The Red-Yellow Podzolic soils have low base content and fertility and require liming and fertilization to produce crops. Most of these soils are best suited for forest or pasture.

The White River Basin has a humid, continental climate with large differences in seasonal temperatures that result in well-defined winter and summer seasons. Typically, differences in temperature between the northern and southern parts of the basin are small. Annual mean air temperature is $51^{\circ} \mathrm{F}$ in the north and $55^{\circ} \mathrm{F}$ in the south. Mean daily air temperature is $28^{\circ} \mathrm{F}$ in mid-January and $76^{\circ} \mathrm{F}$ in mid-July (Governor's Water Resource Study Commission, 1980, p. 9). Average annual precipitation ranges from about $38 \mathrm{in} / \mathrm{yr}$ in the north to about $46 \mathrm{in} / \mathrm{yr}$ in the south-central part of the basin (Owensby and Ezell, 1992). Precipitation is fairly evenly distributed throughout the year. Precipitation in the cooler months of the year generally is of long duration and moderate or low intensity, whereas precipitation in late spring and summer tends to be of shorter duration and higher intensity.

\section{Hydrogeology}

The two general types of aquifers that occur in the White River Basin are unconsolidated aquifers associated with glacial deposits and consolidated aquifers associated with bedrock. The unconsolidated aquifers primarily are composed of glaciofluvial, outwash, and alluvial deposits (fluvial aquifers) that border rivers and streams throughout the basin and sand and gravel deposits in the till plain (Wisconsinan till aquifers) 


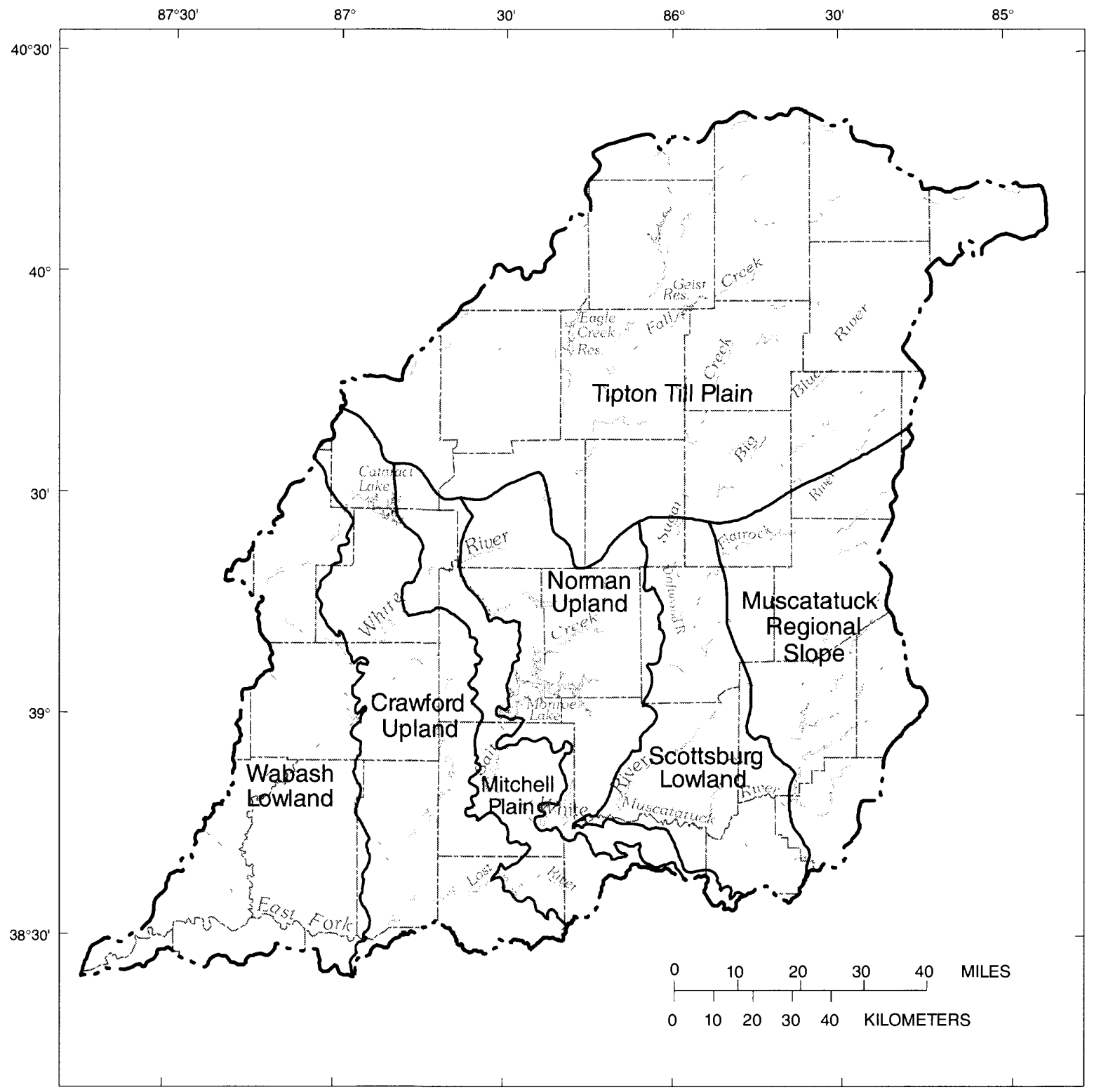

Base from U.S. Geological Survey digital data, 1:100,000, 1983

Albers Equal-Area projection

Standard parallels $29^{\circ} 30^{\prime}$ and $45^{\circ} 30^{\prime}$, central meridian $-86^{\circ}$

\section{EXPLANATION}

-.. White River Basin boundary

County boundary

$\sim$ Geomorphic unit boundary

Figure 2. Geomorphic units in the White River Basin, Indiana (modified from Schneider, 1966, p. 41). 
in the northern half of the basin (Banaszak, 1985, p. 205-210). The fluvial aquifers are the most productive aquifers in Indiana and are composed of sand and gravel associated with stream systems. The fluvial aquifers typically are unconfined, and depth to the water table commonly is 10 to $25 \mathrm{ft}$ (Banaszak, 1988, p. 248). The Wisconsinan till aquifers are composed of isolated sand and gravel lenses enclosed by silty clay and clay till. Wisconsinan till aquifers typically are confined by 5 to $100 \mathrm{ft}$ of fine-grained sediments. Wells screened in these aquifers commonly are 20 to $100 \mathrm{ft}$ deep (Banaszak, 1988, p. 248). The fluvial aquifers described by Banasak (1988) are termed "outwash" aquifers in this report to help maintain the distinction between the type of aquifer and the fluvial deposits hydrogeomorphic region defined and used in later sections of this report.

The consolidated bedrock aquifers primarily are composed of Mississippian limestone in the south-central part of the basin and SilurianDevonian limestone in the eastern one-third of the basin (Banaszak, 1985, p. 205-210). The Mississippian aquifers are composed of fractured limestone containing numerous solution features and sinkholes. Wells in these aquifers are 20 to $150 \mathrm{ft}$ deep (Banaszak, 1988, p. 248). The SilurianDevonian aquifers are composed of fractured limestone and are confined by till in the northeastern part of the basin but lack a confining unit in the southeastern part of the basin. Wells in these aquifers commonly are 50 to $200 \mathrm{ft}$ deep (Banaszak, 1988, p. 248).

\section{Streamflow}

The White River and its major tributary, the East Fork White River, have their headwaters in the northern part of the basin (the headwaters of the East Fork White River is the Big Blue River) and flow to the south and southwest following the regional slope (fig. 1). Long-term average streamflows in the downstream reaches of both forks of the White River are approximately equal. Long-term average flow for the White River at
Petersburg, downstream from the confluence of the east and west forks, is $11,850 \mathrm{ft}^{3} / \mathrm{s}$ (Arvin, 1989, p. 708). This rate of flow represents an average annual runoff of approximately $14.5 \mathrm{in}$. $\left[1.1\left(\mathrm{ft}^{3} / \mathrm{s}\right) / \mathrm{mi}^{2}\right]$.

Daily mean streamflows from 1963-92 were analyzed for the two USGS streamflow-gaging stations on the downstream reaches of the east and west forks (03373500, East Fork White River at Shoals, and 03360500 , White River at Newberry). This analysis indicates that base flow (the streamflow value exceeded 90 percent of the time) in the west fork $\left[0.16\left(\mathrm{ft}^{3} / \mathrm{s}\right) / \mathrm{mi}^{2}\right]$ is greater than base flow in the east fork $\left[0.13\left(\mathrm{ft}^{3} / \mathrm{s}\right) / \mathrm{mi}^{2}\right]$. High flows (the streamflow value exceeded 10 percent of the time) in the east fork $\left[2.8\left(\mathrm{ft}^{3} / \mathrm{s}\right) / \mathrm{mi}^{2}\right]$ are greater than high flows in the west fork $\left[2.5\left(\mathrm{ft}^{3} / \mathrm{s}\right) / \mathrm{mi}^{2}\right]$. Median streamflow for both forks is $0.61\left(\mathrm{ft}^{3} / \mathrm{s}\right) / \mathrm{mi}^{2}$.

Variations in streamflow in the east and west forks of the White River follow seasonal changes in precipitation and evapotranspiration. High flows generally occur in March and April, and low flows generally occur in September and October; annual peak streamflow can occur in any month. Streamflow in small streams is more variable than streamflow in rivers. Peak flows in small streams can be four or more orders of magnitude greater than low flows. The storage capacity of some glacial materials moderates extremes in streamflow. Streams that drain thick till deposits in the northern part of the basin typically have sustained base flow, whereas streams that drain thin glacial deposits or unglaciated areas in the southern part of the basin may go dry (Arihood and Glatfelter, 1991, p. 2, 6).

\section{Population, Land Use, and Water Use}

The population of the White River Basin was approximately 2.1 million people in 1990 . Marion County, which includes the city of Indianapolis, accounted for 38 percent $(797,159$ people) of the total population of the basin (City of Indianapolis, 1991, p. 1; Indiana Business Research 
Center and Indiana University School of Business, 1991). The Indianapolis Metropolitan Area, nearly all of which is contained in the White River Basin, had a population of $1,249,822$ in 1990 (City of Indianapolis, 1991, p. 1). The drainage area of the upstream reach of the White River contains nearly 70 percent of the population of the White River Basin and includes the cities of Muncie, Anderson, Indianapolis, and Martinsville. Population density ranges from 44 people per square mile in Brown County, in the south-central part of the basin, to 2,000 people per square mile in Marion County, where Indianapolis is located.

Statewide, the population of Indiana increased about 1 percent from 5,490,224 in 1980 to 5,544,159 in 1990 (Indiana Business Research Center and Indiana University School of Business, 1991). The fastest growing county in Indiana during this period was Hamilton County, immediately north of Indianapolis, where population increased by 26,909 ( 33 percent). Other counties in the White River Basin that had large increases in population were Marion County (31,926 - 4 percent), Johnson County $(10,869-14$ percent), and Monroe County $(10,193-10$ percent). Delaware County (which includes the city of Muncie) and Madison County (which includes the city of Anderson) had the largest decreases in population $(8,928-7$ percent and $8,667-6$ percent, respectively).

Agriculture is the principal land use in the White River Basin. Approximately 70.2 percent of the basin is used for agriculture, primarily for row crops and pasture. Other important land uses are forest (22.4 percent), urban and residential (6.2 percent), water and wetlands ( 0.7 percent), and active and abandoned quarries and coal mines ( 0.4 percent). The Geographic Information Retrieval and Analysis System (GIRAS) is the source for this land-use information, which was interpreted from aerial photography taken during the 1970's and mid-1980's (U.S. Geological Survey, 1990). Agriculture is the principal land use, except in the bedrock uplands area in the southcentral part of the basin where the principal land use is forest. Most of the urban areas are in the till plain in the northern half of the basin, and most of the coal mining is in the lowland area in the southwestern part of the basin.

Water use in the White River Basin totaled $1,090 \mathrm{Mgal} / \mathrm{d}$ in 1989 , of which 88 percent was surface water and 12 percent was ground water (Indiana Department of Natural Resources, Division of Water, written commun., 1991). The major water use in the basin was cooling water for fossilfuel power-generating plants (64 percent of the total water use). Public water supply accounted for 23 percent of the total water use, whereas commercial, industrial, and irrigation uses accounted for the remaining 13 percent. Of the water withdrawn for public water supply, 85 percent was surface water and 15 percent was ground water. The primary use of ground water in the basin was for public water supply, and approximately 55 percent of the population of the White River Basin relies on ground water as the primary source of drinking water. Although the basin is extensively farmed, irrigation is not necessary in most parts of the basin because the soils tend to hold water for long periods of time. Irrigation is used to increase production on some croplands on well-drained soils in the major flood plains in the south-central and southwestern parts of the basin. Irrigation accounted for approximately 2 percent of the total water use in the basin in 1989 .

\section{Agricultural Practices}

Indiana is an important agricultural state. In 1991, Indiana ranked fourth nationally in soybean production $(172,770,000 \mathrm{bu})$, fifth in corn production $(510,600,000 \mathrm{bu})$, fourth in hog production $(4,600,000$ head), and seventh in turkey production $(15,000,000$ birds) (Indiana Agricultural Statistics Service, 1992, p. 28, 70). Indiana also produced significant amounts of winter wheat $(28,800,000 \mathrm{bu})$, cattle $(1,280,000$ head), and chickens $(25,900,000$ birds $)$. 
Major agricultural products and practices in the White River Basin are similar to those for the entire State. County estimates of land in farms (prorated for the proportion of each county in the White River Basin) indicate that 62.9 percent of the land in the White River Basin is farmland (Indiana Agricultural Statistics Service, 1992). Of the 4.57 million acres of farmland in the basin, 36 percent was planted for corn, 26 percent was planted for soybeans, 5 percent was planted for winter wheat, and 5 percent was harvested for hay. South of Indianapolis, winter wheat often is harvested in the same fields where soybeans are planted to achieve a double crop in those fields. Agricultural products are similar between the east and west forks of the White River.

The growing season in the White River Basin is from early April to late September. The timing of spring planting and fall harvest depends on soil, crop, and weather conditions. Warm, dry conditions enable early planting and harvest, whereas cool, wet conditions delay planting and harvest. Corn planting typically precedes soybean planting, and soybean harvest typically precedes corn harvest. Statewide, 10 percent of the corn is planted by April 20,50 percent by May 7, and 90 percent by May 31. Ten percent of the soybeans is planted by May 4, 50 percent by May 24, and 90 percent by June 19 (Indiana Agricultural Statistics Service, 1992, p. 19, 22). In the fall, 10 percent of the corn is harvested by September 22,50 percent by October 21 , and 90 percent by November 17 . Ten percent of the soybeans is harvested by September 19, 50 percent by October 14, and 90 percent by November 5 (Indiana Agricultural Statistics Service, 1992, p. 21, 25).

Nitrogen and phosphorus are common plant fertilizers applied to Indiana farmlands. From 1980 to 1990 , median annual sales of fertilizers in Indiana were 500,757 tons of nitrogen (as N) and 115,315 tons of phosphorus (as P) (data from Indiana Crop and Livestock Reporting Service, 1985, p. 70-71; Indiana Agricultural Statistics Service, 1988, p. 57; Indiana Agricultural Statistics Service, 1991, p. 66). Independent estimates of the amount of fertilizers applied to corn, soybeans, and wheat were similar to estimates based on fertilizer sales. Estimates of fertilizers applied to corn, soybeans, and wheat were computed as the product of estimates of the acres planted, the average proportion of crop acreage fertilized, and the average application rates of fertilizers. Median annual amounts of fertilizers applied to corn, soybeans, and wheat during 1980-90 were 500,963 tons of nitrogen (as N), and 114,568 tons of phosphorus (as P) (data from Indiana Crop and Livestock Reporting Service, 1985, p. 70-71; Indiana Agricultural Statistics Service, 1988, p. 57; Indiana Agricultural Statistics Service, 1991, p. 66).

Comparison of annual estimates of fertilizer sales and estimates of fertilizers applied to corn, soybeans, and wheat generally shows that fertilizer applied to these crops accounts for the vast majority of fertilizer sales. Trends in fertilizer sales showed decreasing sales of phosphorus fertilizers during 1980-90. Similarly, trends in fertilizer applications to corn, soybeans, and wheat showed decreasing amounts of phosphorus fertilizers applied to these crops (as a group). Trends in the ratio of nitrogen fertilizer applications to sales showed decreasing ratios, which may indicate increasing non-farm use of nitrogen (or increasing use on crops other than corn, soybeans, and wheat).

Of the tons of fertilizer applied to corn, soybean, and wheat, corn receives 90 percent of the nitrogen and 76 percent of the phosphorus. Soybeans receive 1 percent of the nitrogen and 13 percent of the phosphorus. Wheat receives 8 percent of the nitrogen and 10 percent of the phosphorus.

The types and quantities of fertilizers used in the White River Basin and their times of application vary depending on the weather, soil fertility, tillage systems, crop types, crop rotations, yield goals, and the personal preferences of farmers. The most widely used nitrogen-based fertilizers for corn are anhydrous ammonia, 28-percent liquid nitrogen, and urea in the solid form (David Mengel, Purdue University, Department of Agronomy, oral commun., January 1993). 
Corn receives an average of two applications per year of nitrogen-based fertilizer in Indiana (Indiana Agricultural Statistics Service, 1992, p. 66). The first application is at planting (liquid nitrogen or urea) or 1 to 2 weeks before planting (anhydrous ammonia). A second, larger application usually is made after the corn has germinated and is about $1 \mathrm{ft}$ tall. The second application typically occurs no later than mid-June because corn height limits the movement of machinery over the fields. Some farmers may apply nitrogen-based fertilizers after harvest, especially if they plan to grow winter wheat.

Fertilizers are applied more frequently and in greater amounts per acre to corn than to soybeans or wheat. Statistics described in this paragraph are medians of annual estimates for 1980-90. Statewide, Indiana farmers applied nitrogen-based fertilizers to 99 percent of the acres planted to corn, 30 percent of the soybeans, and 95 percent of the wheat. The median nitrogen application rate was $148 \mathrm{lb} /$ acre for corn, $12 \mathrm{lb} /$ acre for soybeans, and $75 \mathrm{lb} /$ acre for wheat. Phosphorus-based fertilizers were applied to 96 percent of the corn, 38 percent of the soybeans, and 90 percent of the wheat. The median phosphorus application rate was $33 \mathrm{lb} /$ acre for corn, $18 \mathrm{lb} /$ acre for soybeans, and $26 \mathrm{lb} /$ acre for wheat (data from Indiana Crop and Livestock Reporting Service, 1985, p. 70-71; Indiana Agricultural Statistics Service, 1988, p. 57; Indiana Agricultural Statistics Service, 1991, p. 66). Analysis of trends (1980-90) in the percentage of crop acres receiving fertilizers showed decreasing percentages of corn and wheat acres receiving phosphorus and decreasing percentages of soybean acres receiving nitrogen. Analysis of trends in fertilizer-application rates showed increasing rates of nitrogen-based fertilizer applied to soybeans.

Indiana farmers use a variety of tillage systems that can be classified as conventional tillage or conservation tillage. Conventional tillage systems often use a moldboard plow and prepare a seedbed that is free of plant residue. Conservation tillage systems include no-till, ridge-till, and mulch-till and are designed to reduce soil erosion by minimizing soil disturbance, protecting the soil surface with growing plants or plant residues, and by increasing surface roughness and permeability (MidWest Plan Service, 1992, p. 3). In general, conservation tillage systems increase infiltration of precipitation and decrease surface runoff and evapotranspiration, thus compared to conventional tillage systems - improving surface-water quality (MidWest Plan Service, 1992, p. 49). Conservation tillage systems were used on 58 percent of Indiana's farmlands in 1992, an increase from 41 percent in 1990 (John Becker, Conservation Technology Information Center, oral commun., January 1993).

Water-saturated soils inhibit planting, harvest, and crop growth, and proper soil drainage is required to prevent the loss of nitrogen from denitrification. Much of the available nitrate can be lost from a warm, water-saturated soil in 2 to 3 days (Voss, 1992, p. 150). Drainage on many poorly drained soils in the White River Basin has been improved for farming by the installation of tile-drain systems. Modern tile drains consist of perforated, flexible tubes buried in trenches in fields beneath the plow zone. The tiles drain water to nearby ditches or streams, quickly removing standing water in fields, draining excess soil moisture in the unsaturated zone, and draining seasonally high ground-water tables. Tile-drain systems "short circuit" natural ground-water flow systems in agricultural fields. Where (and when) tile drains are above ground-water tables, tile drains intercept soil water percolating to the water table and rapidly convey it to streams. Where tile drains are below water tables, tile drains rapidly convey shallow ground water to streams, bypassing the natural flow system in the aquifer. Information on the number and location of tiledrain systems is not available, but agricultural experts expect that nearly all poorly drained farmlands in Indiana contain tile-drain systems (Eileen Kladivko, Purdue University, Department of Agronomy, oral commun., January 1993). 
Approximately 1.2 million hogs and 385,000 cattle are raised in the White River Basin (Indiana Agricultural Statistics Service, 1992, p. 66). Any animal-feeding operation with 300 or more cattle, 600 or more hogs or sheep, 30,000 or more poultry, or any operation causing a water-quality violation is considered a confined-feeding operation and must obtain an operating permit (Indiana Department of Environmental Management, 1993). Animal wastes from confined-feeding operations most commonly are stored in earthen lagoons or concrete waste pits prior to land application. Waste-storage systems constructed after July 1 , 1993, are required to have the capacity to store 120 days of animal waste. However, many confined-feeding operations have less than 120 days storage capacity and, consequently, less flexibility to manage animal wastes.

The IDEM encourages farmers to apply animal wastes to their fields twice a year-prior to spring tillage and in the fall after harvest but before the ground freezes. These recommendations are intended to decrease the potential for nutrient runoff. Although the size of the waste-storage system and field and weather conditions are important factors related to nutrient runoff, usually the most important factor is the operator's commitment to effective animal-waste management (Dennis Lasiter, Indiana Department of Environmental Management, oral commun., July 1995).

\section{Water-Quality Problems}

Water-quality problems in the White River Basin are related primarily to agriculture, urbanization, industrialization, and mineral-resource extraction (Indiana Department of Environmental Management, 1988, 1990; Jacques and Crawford, 1991). Water-quality standards have been adopted by the State to protect legally designated water uses. Nearly all rivers and streams in the White River Basin are designated for full-body-contact recreation and for aquatic-life uses (327 Indiana
Administrative Code 2-1-3). Water-quality data and other information were evaluated by the IDEM to assess progress in meeting the fishable and swimmable water-quality goals of the Clean Water Act.

In the East Fork White River Basin, 54 percent of the assessed stream miles fully supported aquatic-life uses, but none of the assessed stream miles fully supported full-body-contact recreation; whereas in the remainder of the White River Basin, 82 percent fully supported aquatic-life uses but only 5 percent fully supported full-body-contact recreation (Indiana Department of Environmental Management, 1994, p. 303, 314). A primary cause of nonsupport of aquatic-life uses were fish-consumption advisories for polychlorinated biphenyls (PCB's) or chlordane in fish tissue, whereas a primary cause of nonsupport of fullbody-contact recreation was bacterial contamination of stream water (Indiana Department of Environmental Management, 1994, p. 9, 303, 314). Other constituents that have impaired water quality in the basin are ammonia, metals, suspended solids, biochemical oxygen demand, and low concentrations of dissolved oxygen (Indiana Department of Environmental Management, 1994, p. 297-300, 305-309). Statewide, the major sources of impaired stream quality are agricultural nonpoint sources, municipal or semi-public discharges, industrial discharges, urban runoff, and combined-sewer overflows (Indiana Department of Environmental Management, 1994, p. 12, 14).

Nitrate, volatile organic compounds, and metals are the most frequently detected contaminants in Indiana drinking-water wells (Indiana Department of Environmental Management, 1994, p. 3). Important contaminant sources are storage tanks, materials spills, waste-disposal activities, fertilizer and pesticide applications, and septic systems (Indiana Department of Environmental Management, 1994, p. 431, 434). The IDEM estimates that, statewide, about 2 percent of public water-supply wells and about 7 to 10 percent of domestic wells have concentrations of nitrate in excess of $10 \mathrm{mg} / \mathrm{L}$ (Indiana Department of Environmental Management, 1994, p. 446). 
Agriculture and urbanization are the major human-related sources of nutrients in the basin. Agricultural fertilizers and farm-animal wastes can be transported from croplands, barnyards, and feedlots to surface and ground water, especially during and after periods of intense rainfall and runoff. Municipal sewage-treatment plants discharge treated domestic sewage and industrial wastewater directly to streams. During storms, combined sewers may overflow directly to streams, and storm runoff can transport lawnand-garden products, pet wastes, and residues from streets, roofs, and storage areas to waterways. Septic systems and leaking sewer lines are additional sources of nutrients to ground water.

Most environmental concerns about nutrients relate to their effects on human and ecosystem health. Concern for nitrate contamination of water supplies initially focused on development of drinking-water standards to prevent methemoglobinemia in human infants (a treatable, rarely fatal disease that interferes with oxygen supply to the body). Additional concerns have arisen over direct toxicity of nitrate, nitrite, and other nitrogencontaining compounds in water, food, and air and their role in the formation of $\mathrm{N}$-nitrosamines, a mammalian carcinogen (Shuval, 1977; National Research Council, 1978, p. 1-8; Lee and others, 1995, p. 245-249). Ecologic concerns for nutrients focus on their undesirable effects related to eutrophication (nutrient enrichment) of surface water, particularly lakes and estuaries. Also of ecologic concern are the acutely toxic and sublethal effects of ammonia on fishes and other aquatic organisms. Sublethal effects include reduced reproductive success, reduced rates of growth, and pathologic changes in tissues (U.S. Environmental Protection Agency, 1986, p. 31). Additionally, some concerns relate to the role of nitrous oxide (produced in soils by denitrification) in acid rain, its effects on atmospheric ozone, and the effects of nitrous oxide on nitrogen cycles in the oceans (National Research Council, 1978, p. 9-18).
The major nutrients responsible for eutrophication are nitrogen and phosphorus because they typically are the limiting nutrients to the growth of aquatic plants (Wetzel, 1975, p. 640). Although the factors responsible for eutrophication are extremely complex, phosphorus generally is considered to be the most growth-limiting nutrient in lakes, whereas nitrogen generally is considered to be most growth-limiting in estuaries (Wetzel, 1975, p. 243-245, 639-644; National Research Council, 1978, p. 10-12, 385-399; Hem, 1985, p. 128-129). Although nutrients comprise 17 elements universally essential for plant growth (Brady, 1974, p. 20-23), the nutrients considered in this water-quality assessment are limited to nitrogen and phosphorus.

The biogeochemical cycle of nitrogen is extremely complex, with many sources, sinks, and pathways for the transformation of nitrogen among a variety of nitrogen-containing compounds (National Research Council, 1978). The major nitrogen-containing compounds in water are nitrate $\left(\mathrm{NO}_{3}{ }^{-}\right)$, organic nitrogen, nitrite $\left(\mathrm{NO}_{2}{ }^{-}\right)$, and ammonium $\left(\mathrm{NH}_{4}{ }^{+}\right)$(Hem, 1985, p. 124-126). Nitrogen gas $\left(\mathrm{N}_{2}\right)$ also is present in water but is relatively inert and has not been the subject of as much study or concern as the other compounds. Nitrogen gas is converted by blue-green algae and certain species of bacteria into various nitrogencontaining compounds by a process know as "nitrogen fixation." Nitrogen in reduced forms (organic nitrogen and ammonium) may be oxidized into nitrite and nitrate by a process known as "nitrification." Nitrite and nitrate also may be reduced to nitrous oxide or nitrogen gas by a process known as "denitrification."

Ammonium adsorbs to soil particles and sediments by cation exchange and can be transported by soil erosion or sediment movement. Nitrite is an unstable, transition product in the conversion of organic nitrogen or ammonium to nitrate and in the conversion of nitrate to nitrogen gas. Organic nitrogen is nitrogen contained in the amino acids and other complex chemical components of living or dead tissues. Bacteria 
produce ammonium from organic nitrogen through the process of decay. High concentrations of nitrite or organic nitrogen often indicate pollution by sewage or other organic wastes (Hem, 1985, p. 124). Nitrate is a soluble and relatively stable form of nitrogen and is readily transported by water.

Orthophosphate $\left(\mathrm{PO}_{4}{ }^{3-}\right)$ and other phosphate-containing compounds $\left(\mathrm{H}_{3} \mathrm{PO}_{4}\right.$, $\mathrm{H}_{2} \mathrm{PO}_{4}{ }^{-}$, and $\mathrm{HPO}_{4}{ }^{2-}$ ) are the major phosphoruscontaining compounds in water (Hem, 1985, p. 126). Sources of phosphorus include the mineral apatite, sewage and animal wastes, detergents, and fertilizers. The adsorption of phosphate to soils and sediments and its uptake by aquatic vegetation limit the concentration of dissolved phosphorus in water to no more than a few tenths of milligram per liter (Hem, 1985, p. 126). Phosphorus adsorbs to soils and sediments and can be transported by erosion and sediment movement. About 95 percent of the phosphorus transported by rivers is in the particulate (adsorbed) form (Meybeck, 1982).

\section{HYDROGEOMORPHIC REGIONS OF THE WHITE RIVER BASIN}

One of the goals of the NAWQA Program is to understand the natural and human factors that affect water quality. To examine the effects of natural factors on water quality, the White River Basin was subdivided into discrete "hydrogeomorphic regions" that have distinct and relatively homogeneous natural characteristics (Gilliom and others, 1995 , p. 6-12). The natural characteristics include bedrock and glacial geology, geomorphology, hydrology, major soil associations, and ecoregions. Bedrock geology was the major factor used to delineate three regions: the bedrock uplands, the bedrock lowland and plain, and the karst plain. Glacial geology was the major factor used to delineate the other regions: the till plain, the glacial lowland, and the fluvial deposits (used only for ground-water quality).

\section{Bedrock Uplands}

The bedrock uplands region comprises the Crawford Upland and Norman Upland geomorphic units described earlier in this report (figs. 2 and 3). These units are in the south-central part of the basin and are separated by the karst plain region. The Norman Upland was formed from resistant siltstone and shale, and the Crawford Upland was formed from resistant sandstone and limestone. Except for pre-Wisconsinan till that covers the northernmost parts of these units, the bedrock uplands region has not been glaciated. The highly dissected topography of the bedrock uplands region exhibits narrow, flat-topped ridges; steeply sloping hillsides; and deep, V-shaped valleys. Local relief is as much as $300 \mathrm{ft}$, and flood plains are narrow or absent. Soils are thin, acidic, and poorly suited for agriculture. Stony loam is the soil surface texture, and the subsoil is slowly permeable (Bushnell, 1944, p. 32-33). Most of the land is in forest, although pasture and row crops commonly occur in the valleys and on some of the broader hilltops.

\section{Bedrock Lowland and Plain}

The bedrock lowland and plain region comprises the Muscatatuck Regional Slope and the Scottsburg Lowland geomorphic units (figs. 2 and 3). These units are contiguous and are in the southeastern part of the basin. The Muscatatuck Regional Slope is a westward-dipping plain that was formed from resistant Silurian and Devonian limestone and dolomite, and the Scottsburg Lowland was formed from soft Devonian and Mississippian shale. The entire extent of this region has been covered by pre-Wisconsinan till or lake deposits, but the northern third also has been covered by Wisconsinan till. Because the till is thin in the central and southern parts of the region, surface topography is controlled by the bedrock. Average thickness of glacial till is 20 to $25 \mathrm{ft}$, but in places it is no more than 5 to $10 \mathrm{ft}$ thick (Schneider, 1966, p. 44). Upland areas of the bedrock lowland and plain region are broad and nearly flat. Streams cut deep valleys through 


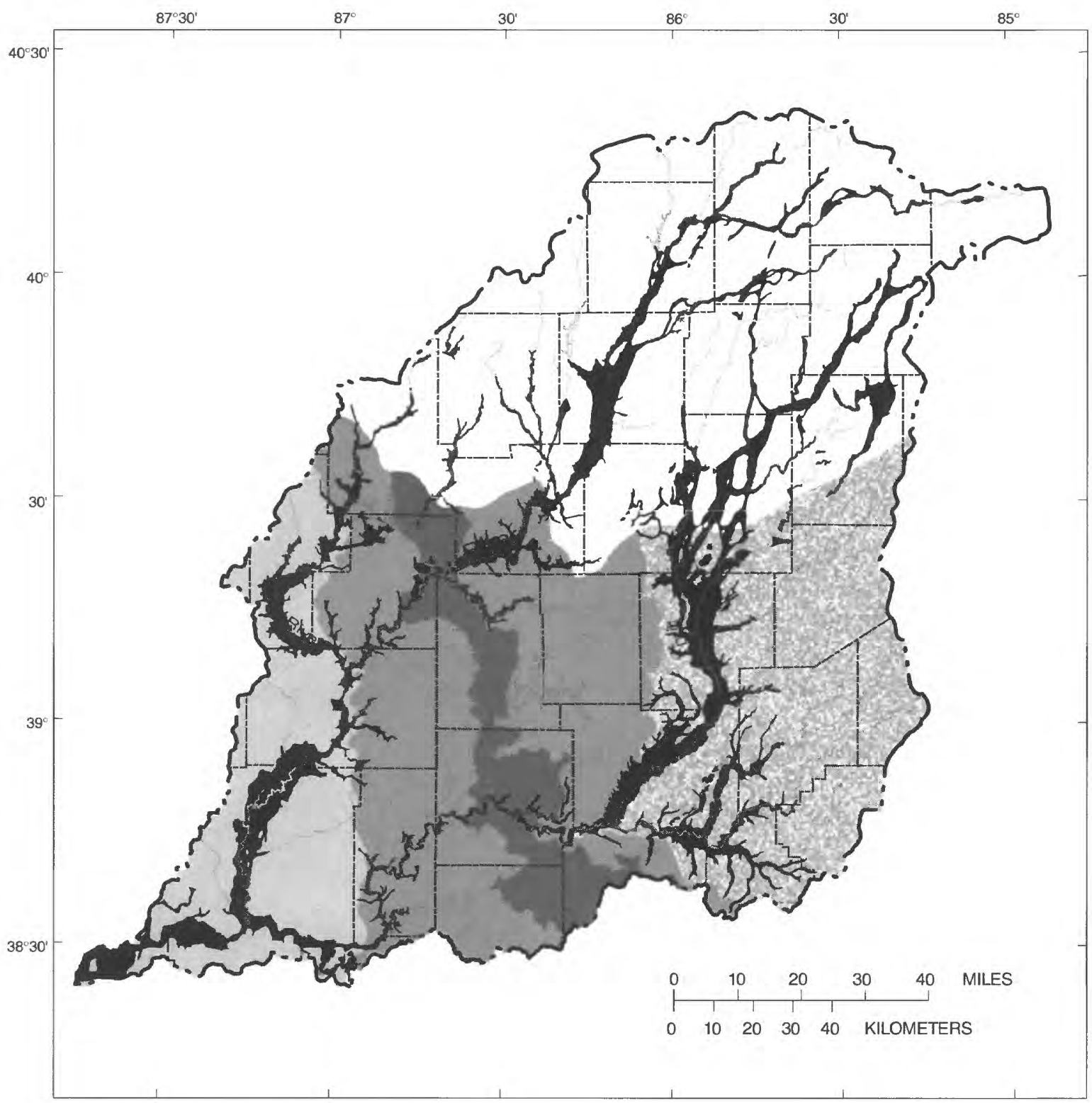

Base from U.S. Geological Survey digital data, 1:100,000, 1983 Albers Equal-Area projection

Standard parallels $29^{\circ} 30^{\prime}$ and $45^{\circ} 30^{\prime}$, central meridian $-86^{\circ}$

\section{EXPLANATION}

HYDROGEOMORPHIC REGIONS

\begin{tabular}{lll}
$\square$ & Till plain & Bedrock lowland and plain \\
Bedrock uplands & Karst plain \\
$\square$ & Glacial lowland \\
\hline
\end{tabular}

- White River Basin boundary

County boundary

Figure 3. Hydrogeomorphic regions used to investigate water quality in the White River Basin, Indiana. 
the upland till and expose bedrock. Most soils have developed in about $3 \mathrm{ft}$ of loess and are either poorly drained or highly erosive (Ulrich, 1966, p. 83). The texture of surface soils is primarily silt loam, and the subsoil is slowly to very slowly permeable. Subsurface drainage is difficult because tiles tend to fill with silt or because it is difficult to find an outlet for the tiles. Row-crop agriculture is the dominant land use throughout the bedrock lowland and plain region.

\section{Karst Plain}

The karst plain region is the Mitchell Plain geomorphic unit, located in the south-central part of the basin between the two units that compose the bedrock uplands region (figs. 2 and 3). Like the bedrock uplands region, only the northernmost part of the karst plain has been glaciated. The karst plain is a moderately sloping, undulating upland area of low relief that formed from soluble Mississippian limestone. The karst plain, particularly the western half of the region, contains numerous sinkholes and solution features and is characterized by short, discontinuous surface streams that drain to sinkholes. More than 1,000 sinkholes were counted in $1 \mathrm{mi}^{2}$ in the center of this region (Schneider, 1966, p. 47). Shapes of the sinkholes vary, but a typical sinkhole is funnel-shaped in cross section -10 to $30 \mathrm{ft}$ deep and $150 \mathrm{ft}$ in diameter. Karst plain soils have developed in a thin, discontinuous layer of loess and a baserich residuum of clay. Soils are silt loam and have developed fragipans on flat areas (D.P. Franzmeier, Purdue University, Department of Agronomy, written commun., July 1993). In many areas, limestone underlies the slowly permeable red-clay residuum at a depth of only 5 or $10 \mathrm{ft}$ (Ulrich, 1966, p. 79). In the Lost River Basin, the thickness of the red-clay residuum averages $17 \mathrm{ft}$ in the eastern part of the basin and $34 \mathrm{ft}$ in the western part (Ruhe and Olson, 1980, p. 89). Soils in the eastern part of the karst plain are drained more commonly by streams than by sinkholes, are more productive, and are more intensely farmed than soils in the western part of the karst plain. Pasture and row-crops are the dominant land uses throughout the karst plain region.

\section{Till Plain}

The till plain region is the Tipton Till Plain geomorphic unit. This region is the largest of the six hydrogeomorphic regions and is in the northern half of the basin (figs. 2 and 3). The plain is flat to gently rolling and is composed of Wisconsinan till. Many areas contain shallow, closed depressions. Glacial deposits are 50 to $400 \mathrm{ft}$ thick, and isolated lenses of sand and gravel occur in the till. Till plain soils have developed in 10 to 20 in. of loess overlying calcareous loam till and form a patchwork of light- and dark-colored areas. Most surface soils are silt loam, and the subsoil is slowly permeable in level areas or depressions. Till plain soils are among the most productive in the world because they have good water-holding capacity and because they are young and have not been leached of the nutrients provided by pulverized rock in the glacial material (D.P. Franzmeier, Purdue University, Department of Agronomy, written commun., July 1993). Nearly all poorly drained areas in the till plain region have been drained by buried, agricultural field tiles (William Hosteter, Soil Scientist, U.S. Natural Resources Conservation Service, oral commun., September 1995). The large urban areas of Muncie, Anderson, and Indianapolis are in the till plain region, but row-crop corn and soybean agriculture is the dominant land use.

\section{Glacial Lowland}

The glacial lowland region is the Wabash Lowland geomorphic unit in the southwestern part of the basin (figs. 2 and 3). The glacial lowland was formed from shale, sandstone, and limestone 
rocks associated with Pennsylvanian coal deposits. The entire unit is covered by Wisconsinan and preWisconsinan drift composed of till, loess, sand dunes, outwash, and glacial lake deposits. Landforms are characterized by broad, gently sloping valleys with smooth, rounded hills. Uplands are hilly or gently rolling, and relief is moderate. Glacial lowland soils have developed in thick loess deposits or in windblown sand dunes. The well-drained, sand-dune soils form a narrow band along the eastern margin of the White River. Sanddune soils have a low water-holding capacity, and the subsoil is permeable. Soils that have formed in loess deposits 5 to $25 \mathrm{ft}$ thick are the most extensive in the glacial lowland (Ulrich, 1966, p. 74).

The surface soils are silt loam, and the subsoils are moderately to slowly permeable. Subsoil permeability is less in the northern part of the region where thinner deposits of loess cover the preWisconsinan till plain (Bushnell, 1944, p. 32-33). Surface coal mining occurs only in this region, but row-crop corn and soybean agriculture is the dominant land use.

\section{Fluvial Deposits}

The fluvial deposits region consists of the narrow band of glaciofluvial deposits beneath and along rivers and streams throughout the White River Basin (fig. 3). In general, the fluvial deposits region corresponds to the area of the flood plain. The glaciofluvial deposits primarily are sand and gravel and were deposited as valley fill as the glaciers melted, but some of the sediment is alluvium composed of silt and clay. Soils of the fluvial deposits region are alluvial soils that have a wide variety of characteristics and properties. In general, finer textured material at the surface overlies coarser material at depth. Surface soil textures generally are loams, and the subsoils are permeable. These soils are among the most productive in Indiana, but where the water table is deep, irrigation is required (D.P. Franzmeier, Purdue University, Department of Agronomy, written commun., July 1993). Muncie, Anderson, Indianapolis, and many small cities and towns are partially in this region, but row-crop corn and soybean agriculture is the dominant land use. The fluvial deposits region contains the most productive and extensively used aquifers in the White River Basin. The fluvial deposits region was used only to examine the factors affecting ground-water quality because the drainage basins of streams and rivers do not include substantial amounts of this hydrogeomorphic region.

\section{ANALYSIS OF WATER-QUALITY DATA}

Water-quality data for the White River Basin are collected by many organizations for a variety of purposes and programs. Manufacturing industries, electric utilities, waste-disposal facilities, municipal and private sewage-treatment facilities, and coal and other mining operations collect data on the quality and quantity of their discharges to streams. Water-supply utilities collect data on their raw water supplies and the treated water they produce. State and local regulatory agencies collect data to develop and determine compliance with operating permits, discharge permits, drinking-water regulations, and surface- and ground-water-quality regulations and standards. State and Federal natural resource agencies collect water-quality data to help manage and protect the air, water, wetland, fish, wildlife, soil, forest, mineral, and recreational resources in their charge. Scientists in academia, government, and industry collect water-quality data to support research on hydrologic processes and systems. Environmental consultants collect data as part of their work for industry and government.

The water-quality data that have been collected in Indiana address the specific needs of various programs. Consequently, water-quality data are highly diverse in constituents and properties measured, sample-collection protocols, analytical methods, location of monitoring sites, time of sampling, sample frequency, data-storage medium, and availability. 


\section{Sources, Selection, and Methods of Analysis of Water-Quality Data}

Much of the water-quality data that have been collected for the White River Basin is of limited utility for a regional assessment of the natural and human factors that affect nutrient concentrations. Most data-collection programs were of limited spatial extent, usually confined to a single municipality or county. Other programs lacked measurements of the constituents of interest (few sewage-treatment plants measure phosphorus, nitrate, or total nitrogen). Many data-collection programs focused on known or suspected sources of pollution. These data provide information on poor water quality but do not represent typical conditions in the basin. In addition, most programs store water-quality data only in paper files, thus limiting retrieval and use of the data.

\section{Sources of Data Used in Assessing Water Quality}

Four data sets had the most utility for a regional water-quality assessment: (1) the surfacewater-quality monitoring program of the IDEM, (2) a synoptic sampling of nutrients in small streams by the USGS, (3) ground-water-quality data collected by the IDEM and the USGS, and (4) precipitation-quality data collected for the National Atmospheric Deposition Program (NADP).

The IDEM operates a network of surfacewater-quality monitoring sites on the White River, the East Fork White River, and on some of the major tributaries. The purpose of the monitoring program is to "provide basic information which would indicate water quality trends and provide data for the many existing and prospective users of surface water in Indiana" (Indiana Department of Environmental Management, 1986, p. 1). Some of the specific objectives of the program are to determine water quality during changing conditions, indicate sources and effects of pollution, compile data needed to support enforcement, and obtain baseline data to detect changes in pollutants and to guide pollution abatement. Many of the surface-water-quality monitoring sites are located to assess the effects of municipal and industrial discharges in urban areas or to determine the quality of water withdrawn for public supplies. Water samples are collected approximately monthly, and most monitoring sites have a long period of record. Constituents pertinent to this assessment include ammonia, nitrite plus nitrate, organic plus ammonia nitrogen (Kjeldahl nitrogen), and phosphorus. Analysis of these data provides information on changes in water quality along the main drainages, seasonal variations in water quality, and trends in water quality through time. In addition, monitoring sites at and near USGS streamflow-gaging stations enable analysis of the relation of water quality and streamflow and computation of nutrient loads and yields.

The USGS sampled a network of 48 small streams for nutrients during base flow in March 1992. The streams were selected from the major hydrogeomorphic regions in the White River Basin and have no permitted discharges upstream. Because the streams were sampled during an extended period of base flow, surface-water samples are expected to approximate the shallow ground-water quality that discharged to the streams. Constituents pertinent to this assessment include ammonia, dissolved nitrite, nitrite plus nitrate, and phosphorus. Analysis of these data provides information on differences in water quality attributed to hydrogeomorphic regions for a single period in time.

The IDEM and the USGS independently have sampled wells throughout the basin for nutrients as parts of assessment programs for pesticides. Wells were selected for sampling on the basis of well type, aquifer type, and well depth to assess the effect of these factors on pesticide occurrence. The IDEM sampled 90 wells, and the USGS sampled 11 wells; data were collected from 1987 through 1991. Constituents pertinent to the assessment described in this report include ammonia, nitrite plus nitrate, and phosphorus. Analysis of these data provides information on the differences in water quality attributable to well type, aquifer 
type, and well depth. Twenty-five wells had paired samples collected before and during the growing season. Analysis of these data also provides information on seasonal variations in nutrient concentrations in ground water.

The NADP comprises approximately 200 wet-deposition monitoring sites that are sampled weekly throughout the United States (National Atmospheric Deposition Program, 1993, p. 1-14). The objectives of the NADP are to determine the spatial patterns and temporal trends in deposition quality and their effects on human and natural resources. Monitoring sites were located to measure regional deposition, and sites near urban areas and point sources were excluded. Constituents pertinent to this assessment include ammonia and nitrate. Analysis of data from three monitoring sites near the White River Basin provides information on atmospheric deposition of nitrogen in the basin.

\section{Field and Laboratory Methods}

River samples for IDEM's surface-waterquality monitoring program usually were collected from bridges from the center of flow by use of a Kemmerer sampler or plastic bucket suspended from a rope (Indiana State Board of Health, 1982, p. 3). Samples were collected from just beneath the water surface. Water samples were not filtered to remove suspended sediment. Therefore, water in the sample bucket was agitated to maintain suspension of sediment particles, then poured into plastic or glass containers. Chemical analyses of these whole-water samples were for "total" concentrations (concentrations dissolved in the water and in and on suspended sediment). Water samples were preserved with sulfuric acid to a $\mathrm{pH}$ less than 2 and stored on ice for transport to the Indiana State Board of Health laboratory for chemical analysis.
The Indiana State Board of Health laboratory is certified by the U.S. Environmental Protection Agency (USEPA) for chemical analyses under the Safe Drinking Water Act (Deborah Hall, Indiana State Board of Health, Bureau of Laboratories, oral commun., April 1994). The Indiana State Board of Health laboratory uses analytical methods approved for water and waste monitoring for the Safe Drinking Water Act and National Pollutant Discharge Elimination System (NPDES). Specifically, ammonia was analyzed by USEPA method 350.1 , nitrite plus nitrate was analyzed by USEPA method 353.2, ammonia plus organic nitrogen was analyzed by USEPA method 351.2, and phosphorus was analyzed by USEPA method 365.1 (U.S. Environmental Protection Agency, 1983). Detection limits were $0.1 \mathrm{mg} / \mathrm{L}$ for ammonia, $0.1 \mathrm{mg} / \mathrm{L}$ for nitrite plus nitrate, $0.1 \mathrm{mg} / \mathrm{L}$ for ammonia plus organic nitrogen, and $0.03 \mathrm{mg} / \mathrm{L}$ for phosphorus.

Water samples for the USGS small-stream network were collected by dipping a glass jar into the stream at several points in the cross section. Water was composited in a churn and filtered onsite. Chemical analyses of these filtered-water samples were for "dissolved" concentrations. Water samples were preserved with mercuric chloride, stored on ice, and air-mailed to the USGS laboratory in Arvada, Colo. USGS procedures for sample collection and processing are described in Ward and Harr (1990). Ammonia, nitrite, nitrite plus nitrate, and phosphorus were analyzed by the methods described in Fishman and Friedman $(1989$, p. $315,343,351$, and 367). Detection limits were $0.01 \mathrm{mg} / \mathrm{L}$ for ammonia, $0.01 \mathrm{mg} / \mathrm{L}$ for nitrite, $0.05 \mathrm{mg} / \mathrm{L}$ for nitrite plus nitrate, and $0.01 \mathrm{mg} / \mathrm{L}$ for phosphorus.

Ground-water samples collected by the IDEM were obtained from domestic or public water-supply wells. Samples were collected at the tap before any treatment and after the plumbing had been flushed for at least 15 minutes. Samples were not filtered; therefore, analyses were for 
"total" concentrations. Samples were preserved onsite and sent to the Indiana State Board of Health laboratory or to a contract laboratory where they were analyzed by methods approved for the Safe Drinking Water Act described previously. Detection limits were 0.05 or $0.1 \mathrm{mg} / \mathrm{L}$ for ammonia, 0.05 or $0.1 \mathrm{mg} / \mathrm{L}$ for nitrite plus nitrate, and 0.01 or $0.03 \mathrm{mg} / \mathrm{L}$ for phosphorus.

Ground-water samples collected by the USGS were obtained from observation wells by use of a peristaltic pump or a submersible, positivedisplacement pump. Wells were purged until field measurements of temperature, $\mathrm{pH}$, and specific conductance became stable. Water samples were filtered onsite and analyses are for "dissolved" concentrations. Filtered samples were preserved, stored on ice, and air-mailed to the USGS laboratory in Arvada, Colo. Samples were analyzed by the methods described in Fishman and Friedman (1989). Detection limits were $0.01 \mathrm{mg} / \mathrm{L}$ for ammonia, $0.05 \mathrm{mg} / \mathrm{L}$ for nitrite plus nitrate, and $0.01 \mathrm{mg} / \mathrm{L}$ for phosphorus. USGS procedures for ground-water sample collection and processing are described in Hardy and others (1989).

Precipitation samples for the NADP were collected in an automatic, wet/dry deposition collector. The collector consists of two sampling containers that were alternately covered. The wetdeposition container was open during precipitation but was covered at all other times. Precipitation in the wet-deposition container was removed weekly and mailed to the Central Analytical Laboratory of the Illinois State Water Survey for chemical analysis. Nitrate was analyzed by ion chromatography, and ammonia was analyzed by autocolorimetry (Peden and others, 1986). Precipitation volume was measured with a 12 -in. recording rain gage.

\section{Data Compilation, Screening, and Methods of Analysis}

The IDEM surface-water-quality monitoring network comprises 31 active sites in the White River Basin (Indiana Department of Environmental Management, 1991, p. 19). Data also have been collected at several discontinued sites in the basin. Water-quality data are published annually and are entered into USEPA's STOrage and RETrieval (STORET) data base. Data were retrieved from STORET and entered into the USGS National Water Information System (NWIS) data base.

The IDEM monitoring sites have variable periods of record, sampling frequencies, and water-quality constituents. To facilitate comparisons and interpretations of water quality among sites, a common period of record was selected. The period selected was the 1981-90 water years (October 1, 1980, through September 30, 1990). This 10-year period was selected to provide information on recent water-quality conditions and to maximize the number of sites (23) for assessment.

Site WR205, White River at Centerton, was discontinued in 1986 and moved 5 mi upstream to site WR210, White River at Waverly. Data from site WR205 were merged with data from site WR210 to provide a continuous period of record for the assessment period. No other data were merged.

Nutrient data for the 1981-90 water years were retrieved and compared to the published data reports (Indiana State Board of Health, 1981-1985; Indiana Department of Environmental Management, 1986-91). Concentrations less than the detection limit were not stored in the data base until July 1984. "Less than" remark codes were added by the authors to the NWIS data base on the basis of the published data. Five numerical discrepancies were discovered and resolved in favor of the published data reports. A few unreasonably high concentrations were deleted (for example, a value of $81 \mathrm{mg} / \mathrm{L}$ for nitrite plus nitrate at site WR81 on April 5, 1989) (Indiana Department of Environmental Management, 1990, p. 117).

Only 5 of the 23 IDEM monitoring sites were at USGS streamflow-gaging stations. Daily mean streamflow for six additional IDEM monitoring sites was estimated for the 10-year period from daily mean streamflow at nearby 
USGS gaging stations. To account for differences in drainage area, streamflow at each gaging station was multiplied by the ratio of drainage areas (monitoring-site area/gaging-station area) to obtain an estimated streamflow at the water-quality monitoring site. The maximum drainage-area adjustment was 17 percent; the other five adjustments were less than 9 percent. Daily mean streamflow was not estimated for the remaining 12 IDEM monitoring sites.

Nearly all data collected from the USGS small-stream network were suitable for use in this assessment. Replicate water-quality samples were collected at one site to evaluate overall precision of data collection and analysis. The second and third replicate samples were deleted from the data set to avoid excessively weighting this site.

Ground-water-quality data used in this assessment were retrieved from the USGS NWIS data base. Many wells with nutrient analyses were excluded from the assessment because the source of the water (the type of aquifer) was not specified in the data base. Wells near landfills also were excluded from the assessment to avoid a bias to potential problem areas. The ground-water data for this assessment comprises 101 wells: 90 sampled by the IDEM and 11 sampled by the USGS. Some of the wells had been sampled more than once, usually several months apart. Some of the samples were quality-control replicates (usually duplicates) collected several minutes apart for the purpose of evaluating overall precision; only one of the replicate samples was retained in the data set. If both replicates had analyses for all nutrients, the second replicate was deleted from the data set. If one replicate had one or more missing nutrient concentration, it was deleted from the data set and the replicate with the most complete set of data was retained. Once multiple replicates were deleted, the median concentration was calculated for wells with more than one sample. Median concentrations were used for all ground-water analyses and interpretations except for the analysis of seasonal variations.
NADP data were obtained from the National Atmospheric Deposition Program/National Trends Network Coordination Office at Colorado State University. Annual wet-deposition data from five NADP sites nearest the White River Basin were reviewed; all of the sites had different periods of record. Three sites that bracket the White River Basin had a common 5-year period of record (1986-90 water years) and were used in the assessment.

Concentrations of total nitrogen for the IDEM surface-water-quality monitoring sites were calculated as the sum of the concentrations of total nitrite plus nitrate nitrogen and the concentrations of total organic plus ammonia nitrogen. Data for organic plus ammonia nitrogen were unavailable for most monitoring sites for the 1986-90 water years. Analysis of concentrations of total nitrogen was based only on data for the 1981-85 water years to facilitate comparisons among sites using a common period of record. All nitrogen-containing compounds described in this assessment are reported as equivalent amounts of elemental nitrogen $(\mathrm{mg} / \mathrm{L}$ as $\mathrm{N})$. Both filtered and nonfiltered groundwater samples were collected and were combined for assessment following the approach of Hamilton and others (1989, p. 19). Summary statistics for ground-water analyses with multiple detection limits were calculated by the method of Gilliom and Helsel (1986).

Because concentrations of nitrate typically are two orders of magnitude greater than concentrations of nitrite and because nitrite usually does not exceed $0.5 \mathrm{mg} / \mathrm{L}$ in surface water (National Research Council, 1978, p. 118), concentrations or loads of nitrite plus nitrate are referred to as concentrations or loads of "nitrate" in the text of this report. This simplification is used to reduce wordiness in the text and is reasonable because nitrite is a trivial component of the nitrite plus nitrate laboratory analyses for water samples in the White River Basin. The term "total" is used in the text to indicate the sum of the various chemical forms of nitrogen or phosphorus. The terms "dissolved" and "total," where used to distinguish laboratory analyses of filtered and nonfiltered samples, are not used in the text to 
reduce confusion with the previously described use of the term "total." The terms "nitrite plus nitrate," "total," and "dissolved" are used in the tables and figures to identify the precise laboratory analyses for the data that are reported. Most of the ammonia dissolved in water is in an ionized form called ammonium $\left(\mathrm{NH}_{4}{ }^{+}\right)(\mathrm{Hem}, 1985$, p. 126). "Ammonia" is used for both ammonia and ammonium.

Water-quality data were analyzed by a variety of graphical and statistical methods. The Statistical Analysis System (SAS) ${ }^{1}$ was used to calculate statistics of central tendency and variability (Ray, 1982, p. 575-586). The median was used in this assessment as the primary measure of central tendency. The median is the value at which onehalf of the data is greater than the median and one-half is less than the median. The 10th, 25th, 75 th, and 90th percentiles were used to show the variability of the data. The 10 th percentile is the value at which 10 percent of the data is less than the value and 90 percent is greater than the value. The central tendency and variability of the data are shown graphically in box plots (fig. 4). In this type of plot, a box is drawn from the 25 th to the 75 th percentile, and the median (the 50th percentile) is drawn as a horizontal line in the box. "Whiskers" are drawn from the ends of the box to the 10th and 90th percentiles. The boxplot, therefore, shows the typical value (the median), the middle 50 percent of the data (the box), and the middle 80 percent of the data (the area between the ends of the whiskers). The highest 10 percent and the lowest 10 percent of the data are not shown. These extreme data values are important for interpreting water quality associated with infrequently occurring events, such as floods or droughts, and are discussed in the text where appropriate.

\footnotetext{
${ }^{1}$ The use of brand names in this report is for identification purposes only and does not imply endorsement by the U.S. Geological Survey.
}

Seasonal variations in surface-water quality were determined by comparing boxplots of concentrations grouped into six seasons. Each season comprised two months (October/November, December/January, and so forth). Seasonal variations in ground-water quality were determined by comparing samples collected during March (which represents the dormant season) to samples collected during June, July, or August (which represent the growing season). The number of samples collected at various rates of streamflow was determined by calculating 10-percentile intervals of streamflow using all daily values for the 1981-90 water years and assigning samples to the 10 streamflow classes (percentiles of streamflow).

SAS was used to compute Kendall's tau (Conover, 1980, p. 256), a nonparametric measure of the association between two variables, for correlations between nutrient concentrations and streamflow, nutrient concentrations and well depth, and between nutrient concentrations and time (also called the Mann-Kendall test for trend). Approximate significance probabilities for the correlations also were computed using SAS (Ray, 1982, p. 501-512). The null hypothesis of no association between variables was rejected if the probability of obtaining the correlation by chance was less than or equal to 0.05 . Scatterplots with locally weighted scatterplot smooths (LOWESS) were drawn to show the relations of nutrient concentrations to streamflow, depth, and time (Cleveland, 1979). The smooth shows the general form of the relationship.

Visual inspection of time-series plots, the Mann-Kendall test for correlation between concentration and time (Helsel and Hirsch, 1992, p. 326-328), and the seasonal Kendall test for trend and trend slope estimator (Hirsch and others, 1982) were the primary methods of trend detection and quantification used in this study. The null hypothesis of no trend was tested, and apparent trends were identified if either statistical test 


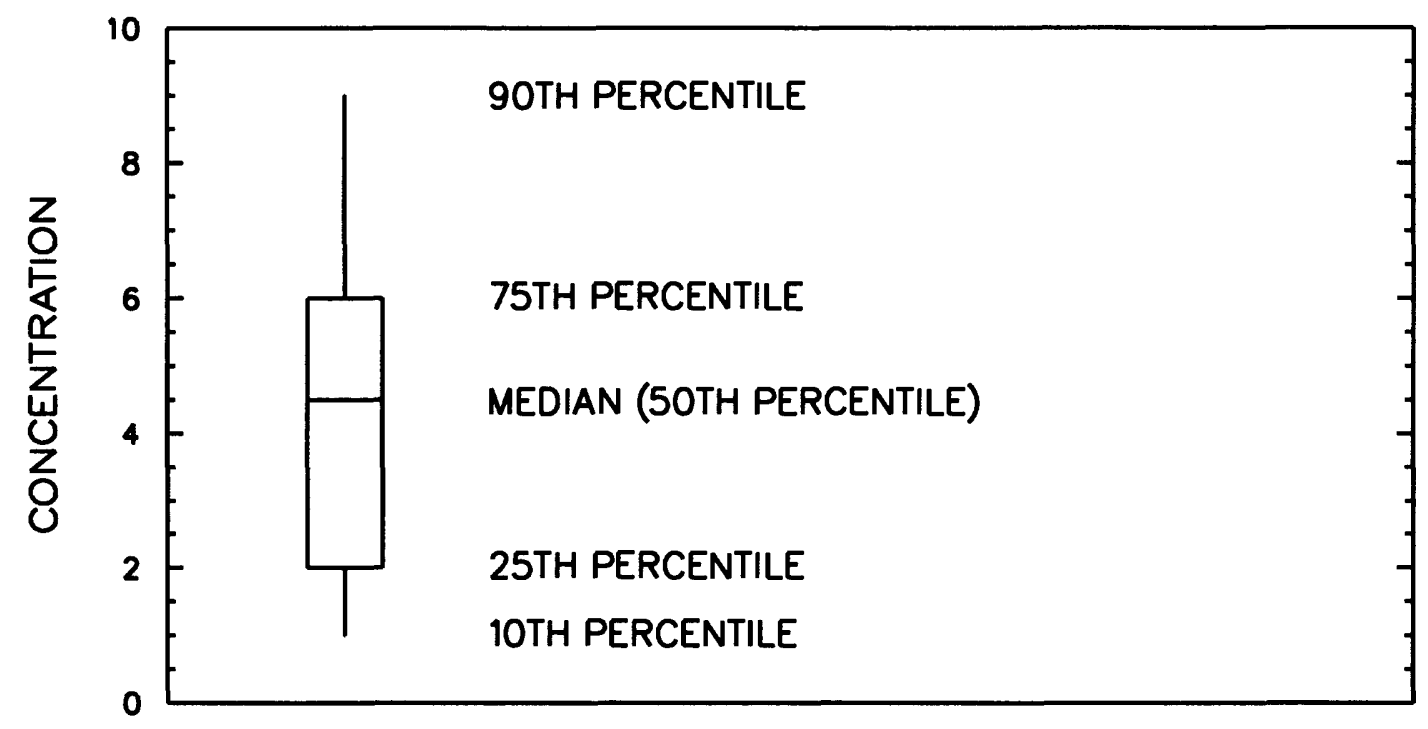

Figure 4. Example boxplot showing central tendency and variability of water-quality concentrations. (The highest 10 percent and lowest 10 percent of the concentrations are not shown.) 
indicated a statistically significant trend at the 0.05 probability level. Generally, the MannKendall and seasonal Kendall tests gave similar results. In a few cases, the Mann-Kendall test and visual inspection identified a trend, but the seasonal Kendall test did not (for example, total phosphorus at site WR279). The seasonal Kendall test is insensitive to cases of increasing trends in some seasons and decreasing trends in others (Hirsch and others, 1982, p. 111), even if the trends in one direction are much larger than those in the other. The Mann-Kendall test does not account for seasonality but was used to determine if the median concentration has changed over time.

Because nutrient concentrations and streamflow are correlated at some monitoring sites, concentrations were adjusted for the effect of streamflow and tested for time trends. Streamflowadjusted concentrations were calculated as the residuals from a LOWESS fit to the concentrationstreamflow relation and were tested for trends by using the seasonal Kendall test (Helsel and Hirsch, 1992, p. 329-331). Time trends in streamflowadjusted concentrations were examined to see if apparent trends (or lack of trends) in concentrations could have been attributed solely to the particular sequence of streamflows for days when water-quality samples were collected. For example, suppose that nutrient concentration is correlated with streamflow, that most of the samples in the early part of a test period were collected during low flow, and that most of the samples in the late part of a test period were collected during high flow. Trend tests on the unadjusted nutrient concentrations probably will indicate a statistically significant trend when, in fact, the processes delivering or transporting nutrients in the stream have not changed. Trend tests on the streamflow-adjusted nutrient concentrations probably will indicate the lack of a statistically significant trend because the effect of streamflow has been removed.
The use of streamflow-adjusted concentrations in interpreting trends in water quality requires a stationary (time-trend free) streamflow record (Helsel and Hirsch, 1992, p. 332). This requirement may not have been met at several of the monitoring sites in the upstream reach of the White River because increases (at Carmel) and decreases (at Muncie and Anderson) in the discharge rates of several sewage-treatment plants may have changed the probability distribution of base flow. The degree to which this requirement was met at the other monitoring sites, particularly those with small drainage areas or large upstream water users, is not known and is beyond the scope of this study.

Rank-transform analysis of variance (ANOVA) was performed on base-flow water-quality samples from the USGS smallstream network to test the null hypothesis that hydrogeomorphic regions had no effect on mediannutrient concentrations (Conover and Iman, 1981; Helsel and Hirsch, 1992, p. 163). ANOVA was done on the ranks of the concentrations to eliminate the assumption of normally distributed data required by traditional ANOVA. Rank-transform ANOVA is comparable to the Kruskal-Wallis test (Hollander and Wolfe, 1973, p. 115). The Tukey method of multiple comparisons (Neter and others, 1985 , p. 574) was used to determine which regions were different from the others. Probabilities less than or equal to 0.05 were considered statistically significant.

The transport (mass discharge) of a nutrient past a monitoring site in a given amount of time is referred to as the nutrient "load" and was calculated by the rating-curve method (Cohn and others, 1989; Crawford, 1991). Because many of the nutrient concentrations included in this assessment were less than the detection limit, parameters of the rating curve were estimated by maximum-likelihood methods (Dempster and others, 1977; Wolynetz, 1979). Water-quality samples used for load calculations were collected as surface grab samples from the center of flow. 
This collection technique commonly yields concentrations of sediment-associated nutrients that are biased low (Feltz and Culbertson, 1972; Martin and others, 1992). Consequently, loads calculated for total nitrogen and total phosphorus probably are biased low.

Because of improvements to the two Indianapolis sewage-treatment plants, the relation between nutrient concentrations and streamflow at site WR210, downstream from the treatment plants, was not constant throughout the assessment period. Consequently, the rating-curve method was used to compute separate loads for the periods from October 1, 1980, to December 31, 1982 (the period before improvements became operational), and from January 1, 1983, to September 30, 1990 (the period after improvements became operational). Nutrient loads for site WR210 are a time-weighted average of the loads for these two periods. Loads of total nitrogen were calculated as the sum of the loads of ammonia, nitrate, and organic nitrogen. Loads of organic nitrogen were based only on the organic nitrogen-streamflow relation for the 1981-85 water years because samples for organic plus ammonia nitrogen were not collected at most sites in subsequent years. River yields were calculated as the load divided by the drainage area of the basin.

Mean annual atmospheric wet deposition of ammonia and nitrate in the White River Basin was calculated as the weighted average of the mean annual deposition (1986-90 water years) measured at the three NADP sites near the basin described previously. The inverse squared distance from the NADP site to the center of the basin was the criterion used to weight the mean annual wet deposition at each site. Atmospheric dry deposition of nitrate was estimated by the wet/dry ratio method of Sisterson (1990, appendix A). Increased deposition of nitrate from urban areas also was estimated by the method of Sisterson (1990, appendix A). A droplet correction was not used because of the low land-surface elevation in the White River Basin.
The mass discharge of nutrients from point sources such as sewage-treatment plants and industrial dischargers was calculated from estimates of 1991 annual return flows (Indiana Department of Environmental Management, written commun., 1992) and estimates of total nitrogen and total phosphorus concentrations in the return flows. Estimates of total nitrogen and total phosphorus concentrations in the return flows were based on standardized industrial codes for the industry or treatment plant (Lugbill, 1990; L.J. Puckett, U.S. Geological Survey, written commun., June 1993). Estimated effluent concentrations of total nitrogen and total phosphorus used for all sewage-treatment plants were 11.2 and $7.0 \mathrm{mg} / \mathrm{L}$, respectively. Nutrient mass discharge from facilities with less than $1 \mathrm{Mgal} / \mathrm{d}$ were grouped by county, and the mass was apportioned to monitoring sites on the basis of the proportion of the county in the drainage basin of each site.

Applications of nutrients in commercial fertilizer and animal manure were calculated from national data bases of 1987 fertilizer sales and the 1987 farm-animal census (L.J. Puckett, U.S. Geological Survey, written commun., June 1993). County-level estimates of total nitrogen and total phosphorus content of commercial fertilizer and animal manure were apportioned to monitoring sites on the basis of the proportion of the county in the drainage basin of each site.

Water-quality criteria for ammonia were calculated from equations given in U.S. Environmental Protection Agency (1986, p. 35-36). Un-ionized ammonia concentrations were calculated from equations given in Thurston and others, 1979.

\section{Spatial, Temporal, and Hydrologic Characteristics of Water-Quality Data}

To determine the effect of natural and human factors on water quality, it is critical to collect water samples from appropriate locations and at appropriate times and conditions. The spatial, temporal, and hydrologic characteristics of the water-quality data were examined to ensure that samples were not biased to particular locations, 
seasons, streamflow conditions, aquifers, or other conditions. If samples are biased to particular conditions, an understanding of the bias is important in the interpretation of the results of the analysis.

\section{Monitoring Site Location and Period of Record}

Most of the IDEM monitoring sites are on the White and East Fork White Rivers (fig. 5). Characteristics of the monitoring sites are given in table 1 . The site number is an alphanumeric code comprising the initials of the river name and the river mile where the site is located. For example, site WR81 is on the White River, 81 river mi upstream from its confluence with the Wabash River; site EW168 is on the East Fork White River, 168 river mi upstream from its confluence with the White River. Drainage areas of the monitoring sites range from 35 to $11,125 \mathrm{mi}^{2}$, but most of the sites have drainage areas greater than $300 \mathrm{mi}^{2}$ (table 1). The interpretation of water-quality data collected at sites with large drainage areas can be difficult because of the many natural and human factors that affect water quality in a large area. Monitoring sites draining small areas commonly are affected by similar natural and human factors, and interpretations are more easily made.

Many of the monitoring sites are located to assess the effects of municipal and industrial discharges in urban areas (fig. 6). Consequently, several pairs of monitoring sites are located to bracket the source of interest (Indiana Department of Environmental Management, 1986, p. 14-21). Sites located to monitor these urban sources are site WR309, $2.8 \mathrm{mi}$ downstream from the Muncie sewage-treatment plant; site WR279, $11 \mathrm{mi}$ downstream from the Anderson sewage-treatment plant; site WR248, 3 mi downstream from the Carmel sewage-treatment plant and $14 \mathrm{mi}$ downstream from the Noblesville sewage-treatment plant; site WR210, $12 \mathrm{mi}$ downstream from the Indianapolis
Southport Road sewage-treatment plant and $15 \mathrm{mi}$ downstream from the Indianapolis Belmont Avenue sewage-treatment plant; site BL64, $4 \mathrm{mi}$ downstream from the New Castle sewagetreatment plant; site BL.7, $0.3 \mathrm{mi}$ downstream from the Edinburgh sewage-treatment plant; site EW79, 14 mi downstream from the Bedford sewage-treatment plant; site EC21, 3 mi downstream from the Zionsville sewage-treatment plant; and site EC1, $3 \mathrm{mi}$ downstream from the Speedway sewage-treatment plant. Sites upstream from the source of interest are site WR319, upstream from the Muncie sewage-treatment plant; site WR293, upstream from the Anderson sewage-treatment plant; site WR248, upstream from the Indianapolis sewage-treatment plants; and site EW94, upstream from the Bedford sewage-treatment plant (figs. 5 and 6).

Sites WR319, EW168, EW94, and FC7 are located where surface water is withdrawn for public supplies. Sites WR348 and MC35 have the smallest drainage areas of the monitoring sites and are in areas of intensive agriculture, upstream from any permitted point-source discharges. Sites FC7, EC1, and SLT12 are downstream from large, public water-supply reservoirs. Sites EC21 and MC18 are immediately upstream from large, public water-supply reservoirs (fig. 5).

Water-quality samples were collected monthly at all but four of the monitoring sites (table 1). Except for several samples at the end of 1983 and the beginning of 1984 at some sites, data for ammonia, nitrate, and total phosphorus were complete throughout the assessment period. Most monitoring sites had a period of record similar to site WR81 (fig. 7). The period of record for sites WR348 and EW79 was similar to site WR46; sites WR309 and EC1 were similar to site WR293; site SLT12 was similar to site EW94; and sites BL.7, MC35, and MC18 were similar to site BL64 (fig. 7). Data for ammonia plus organic nitrogen, 


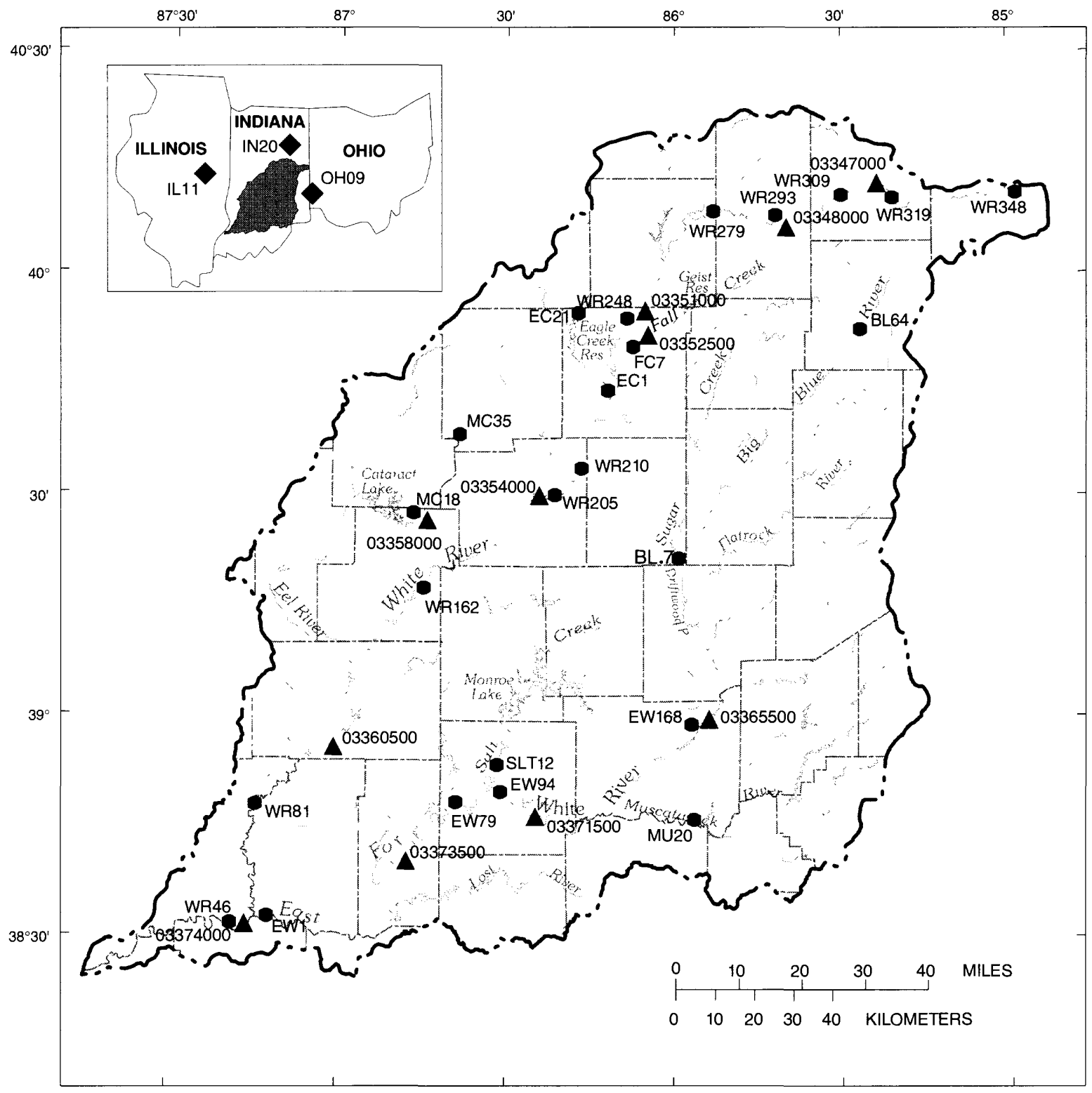

Base from U.S. Geological Survey digital data, 1:100,000, 1983

Albers Equal-Area projection

Standard parallels $29^{\circ} 30^{\prime}$ and $45^{\circ} 30^{\prime}$, central meridian $-86^{\circ}$

\section{EXPLANATION}

\section{MONITORING SITES}

$\begin{array}{ll}03365500 & \begin{array}{l}\text { U.S. Geological Survey streamflow- } \\ \text { gaging station }\end{array}\end{array}$

EW168 Indiana Department of Environmental

- Management surface-water-quality

IN20 monitoring site

National Atmospheric Deposition Program

precipitation-quality monitoring site

White River Basin boundary

_.... County boundary

Figure 5. Location of selected surface-water-quality monitoring sites, streamflow-gaging stations, and precipitation-quality monitoring sites in and near the White River Basin, Indiana, 1981-90 water years. 


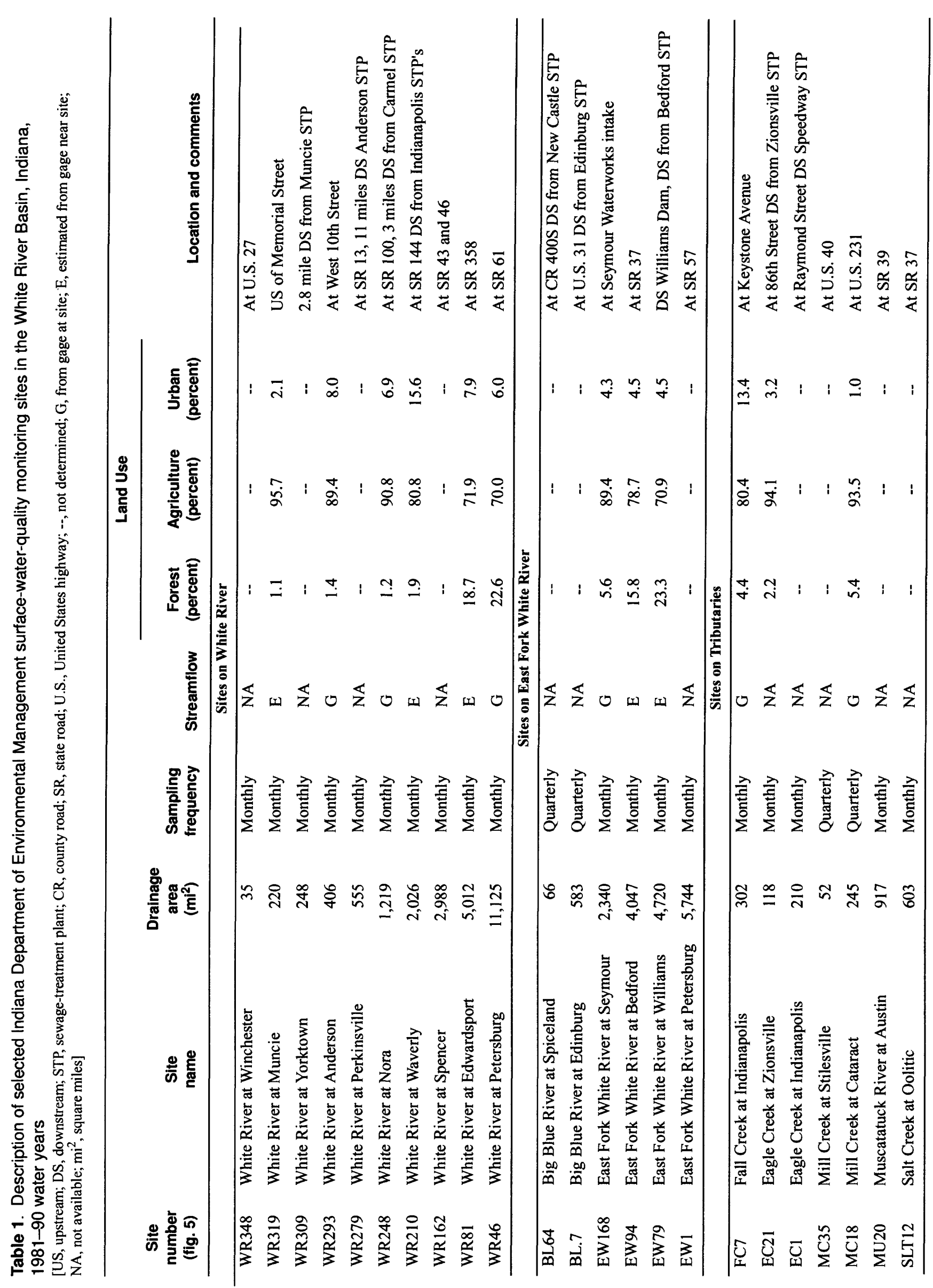

28 Water-Quality Assessment of the White River Basin, Indiana 


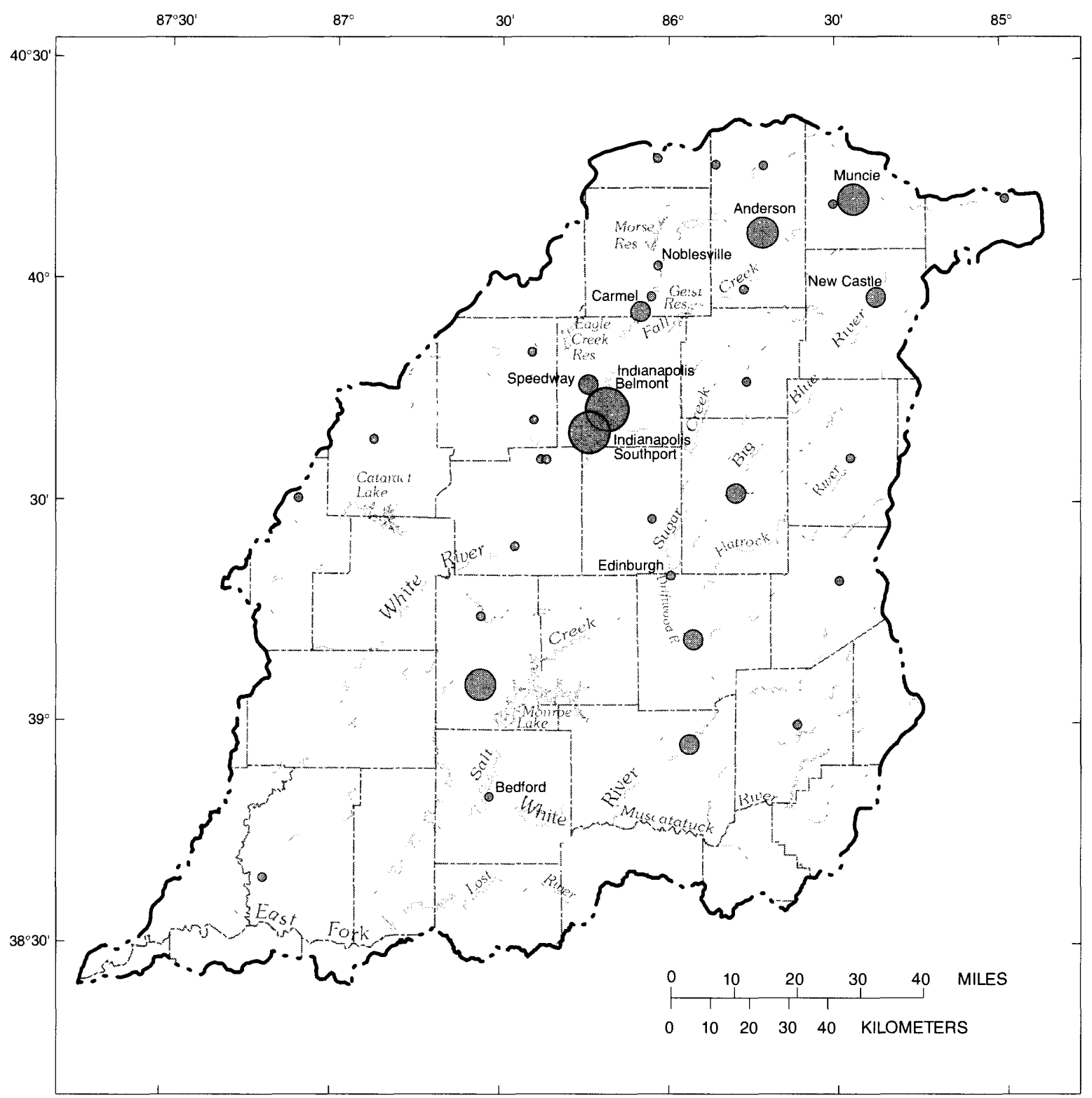

Base from U.S. Geological Survey digital data, 1:100,000, 1983

Albers Equal-Area projection

Standard parallels $29^{\circ} 30^{\prime}$ and $45^{\circ} 30^{\prime}$, central meridian $-86^{\circ}$

\section{EXPLANATION}

Mean daily discharge from municipal

sewage-treatment plants, 1991

(in million gallons per day)

- 1 to 3

3 to 10

(C) 10 to 20

(2) 75 to 90

-.. White River Basin boundary

-.... County boundary

Figure 6. Mean daily discharge from selected municipal sewage-treatment plants in the White River Basin, Indiana, 1991. (Data from Indiana Department of Environmental Management, written commun., 1992.) 

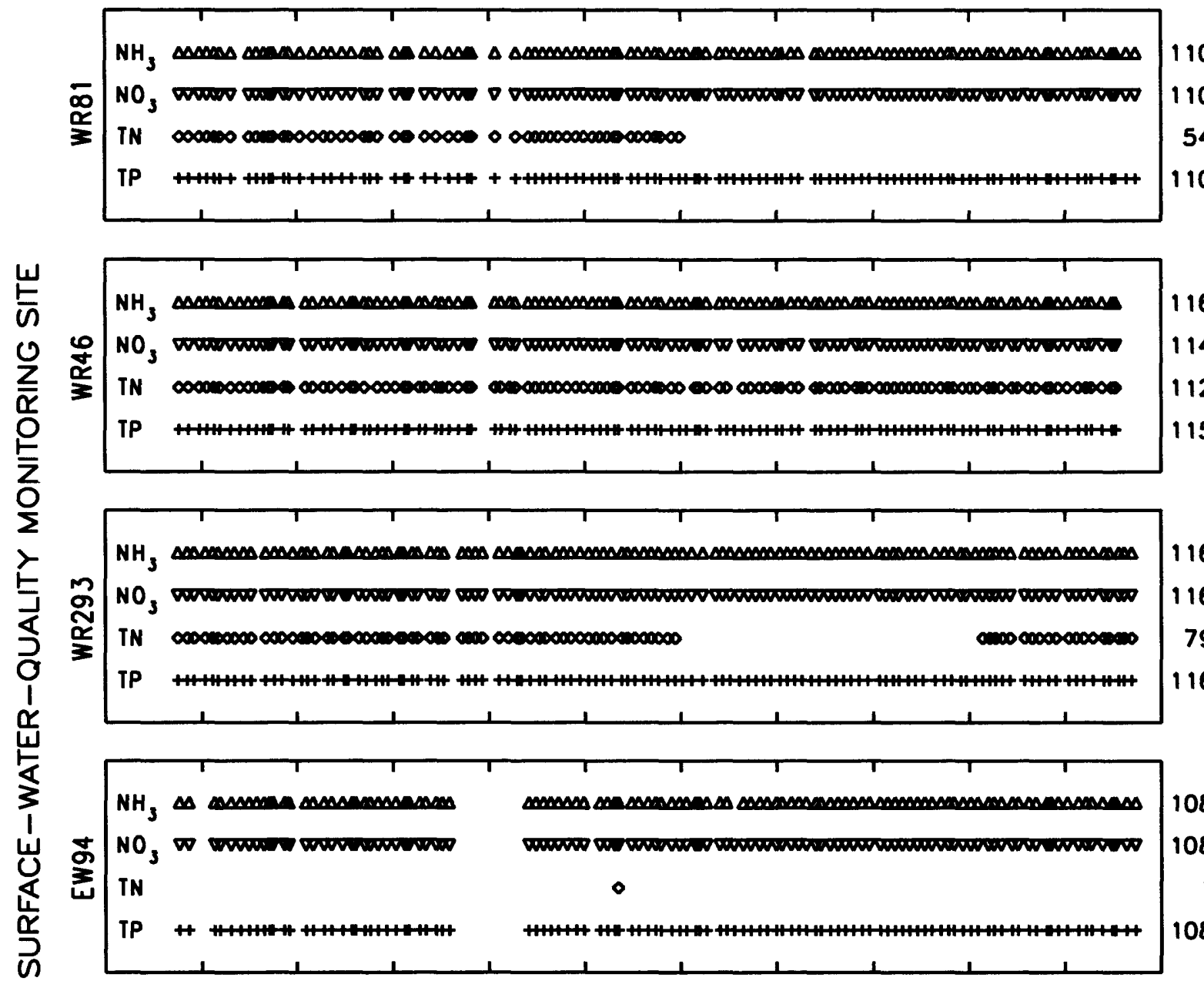

116
116
79
116

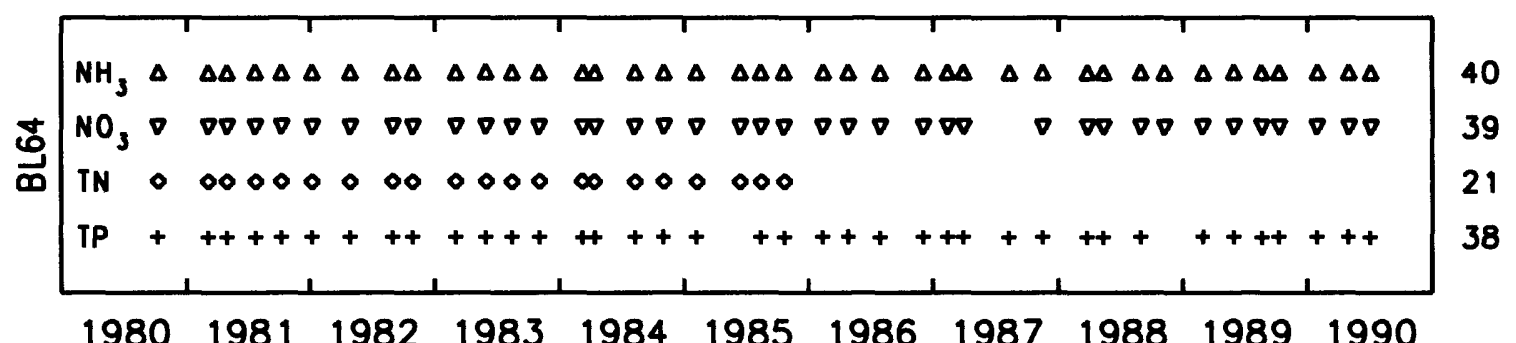

\section{EXPLANATION}
$\Delta$ Tolol ammonio $\left(\mathrm{NH}_{3}\right)$
- Total nitrite plus nitrote $\left(\mathrm{NO}_{3}\right)$
- Tolal nitrogen
(TN)
+ Tolal phosphorus
(TP)

Figure 7. Period of record for nutrient samples collected at selected surfacewater-quality monitoring sites in the White River Basin, Indiana, 1981-90 water years. 
which was used in the calculation of total nitrogen, were complete through 1985 but were no longer collected at most sites beginning in 1986. Analysis and interpretation of total nitrogen are based only on data collected for the 1981-85 water years.

The small-stream network sampled by the USGS comprises 48 sites distributed among five of the six hydrogeomorphic regions of the basin (fig. 8). Sites were located in small headwater streams, upstream from known point-source discharges. Drainage areas ranged from 0.6 to $24.1 \mathrm{mi}^{2}$ (median $6.6 \mathrm{mi}^{2}$ ). Land use in the drainage basin of the stream was typical of that found elsewhere in the hydrogeomorphic regions. Water samples were collected during base flow in March 1992; streamflow ranged from 0.09 to $11 \mathrm{ft}^{3} / \mathrm{s}$ (median $1.5 \mathrm{ft}^{3} / \mathrm{s}$ ). Because the streams were sampled during an extended period of base flow, surface-water samples were expected to approximate the water quality of the shallow ground water that discharged to the streams. Because samples were collected during cold temperatures during early spring, biological uptake or transformation of nutrients was expected to be minimized.

Ground-water samples were collected from 101 wells distributed among the five hydrogeomorphic regions used for surface-water analysis plus the fluvial deposits region used for groundwater analysis (figs. 3 and 9). Few wells were in the glacial lowland region. Ground-water samples were collected from 1987-91.

The precipitation-quality network used in this assessment comprises three NADP sites near the White River Basin (fig. 5): the Bondville site in Champaign County, Ill. (IL11); the Huntington Reservoir site in Huntington County, Ind. (IN20); and the Oxford site in Butler County, Ohio (OH09). Wet-deposition data from these sites for the 1986-90 water years were used to estimate nutrient loading to the basin from atmospheric deposition.

\section{Distribution of Surface-Water Samples by Season and Streamflow}

Water quality is affected by natural and human factors that change seasonally; consequently, water quality changes seasonally. Analyses of the seasonal variations in water quality and the relation of water quality to streamflow are useful ways to group many of the factors that affect water quality and to investigate their overall effect.

To investigate seasonal variations and relations to streamflow, it is necessary to collect water samples at appropriate times and conditions. Seasonal variations in water quality could not be assessed if samples were not collected during all seasons. Similarly, the effects of droughts or floods could not be assessed unless samples were collected during these conditions. It is less obvious that a valid comparison of water quality among monitoring sites is dependent on samples collected during appropriate seasons and streamflow conditions. Without knowledge of the sample times and conditions, one might compare a site with predominantly summer low-flow samples to a site with predominantly spring high-flow samples and conclude that the water quality was different when, in fact, it was not. Typical water-quality conditions are best assessed from samples collected during all seasons and conditions in proportion to how often they occur. For seasonal variations, this is accomplished by collecting equal numbers of samples in each season. For flow-related variations, this is accomplished by collecting samples throughout the range of streamflow. For assessment of mass transport, however, sampling should be targeted to conditions when most of the constituent is transported, usually during floods.

Because samples were collected monthly at the IDEM monitoring sites and because seasons in this assessment are defined in equal groups of months, all IDEM monitoring sites have approximately equal numbers of samples per season. The seasonal distributions of water samples for sites WR248, WR210, WR81, WR46, EW168, and EW79 (fig. 10) were similar to the other monitoring sites. 


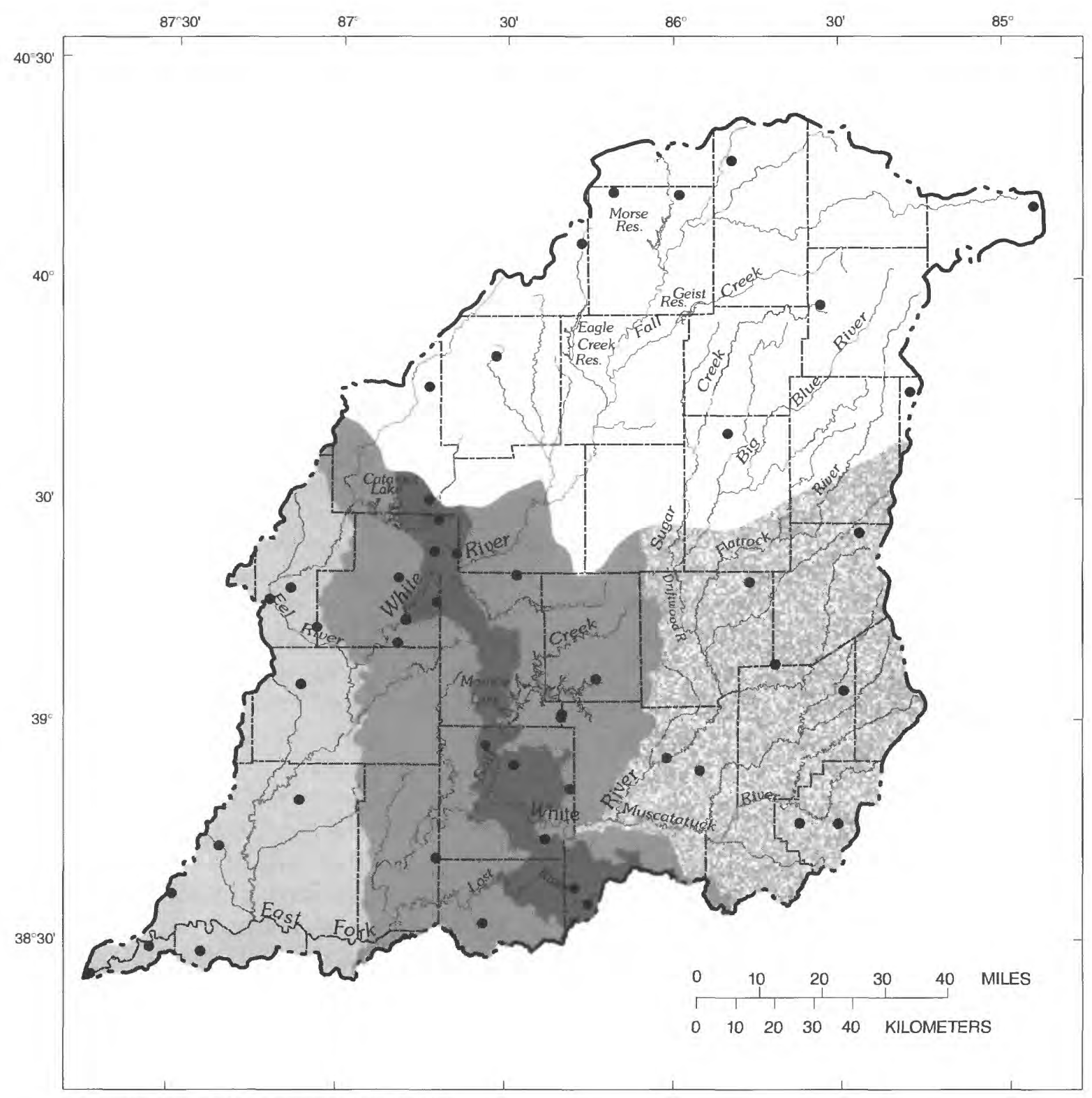

Base from U.S. Geological Survey digital data. 1:100.000, 1983 Albers Equal-Area projection

Standard parallels $29^{\circ} 30^{\prime}$ and $45^{\circ} 30^{\prime}$, central meridian $-86^{\circ}$

\section{EXPLANATION}

SAMPLING SITES

- Base-flow water-quality sampling site

\section{HYDROGEOMORPHIC REGIONS}
Till plain
Bedrock uplands
Karst plain

Bedrock lowland and plain

Glacial lowland

-.. White River Basin boundary County boundary
}

Figure 8. Location of small-stream, base-flow water-quality sampling sites in the White River Basin, Indiana, March 1992. 


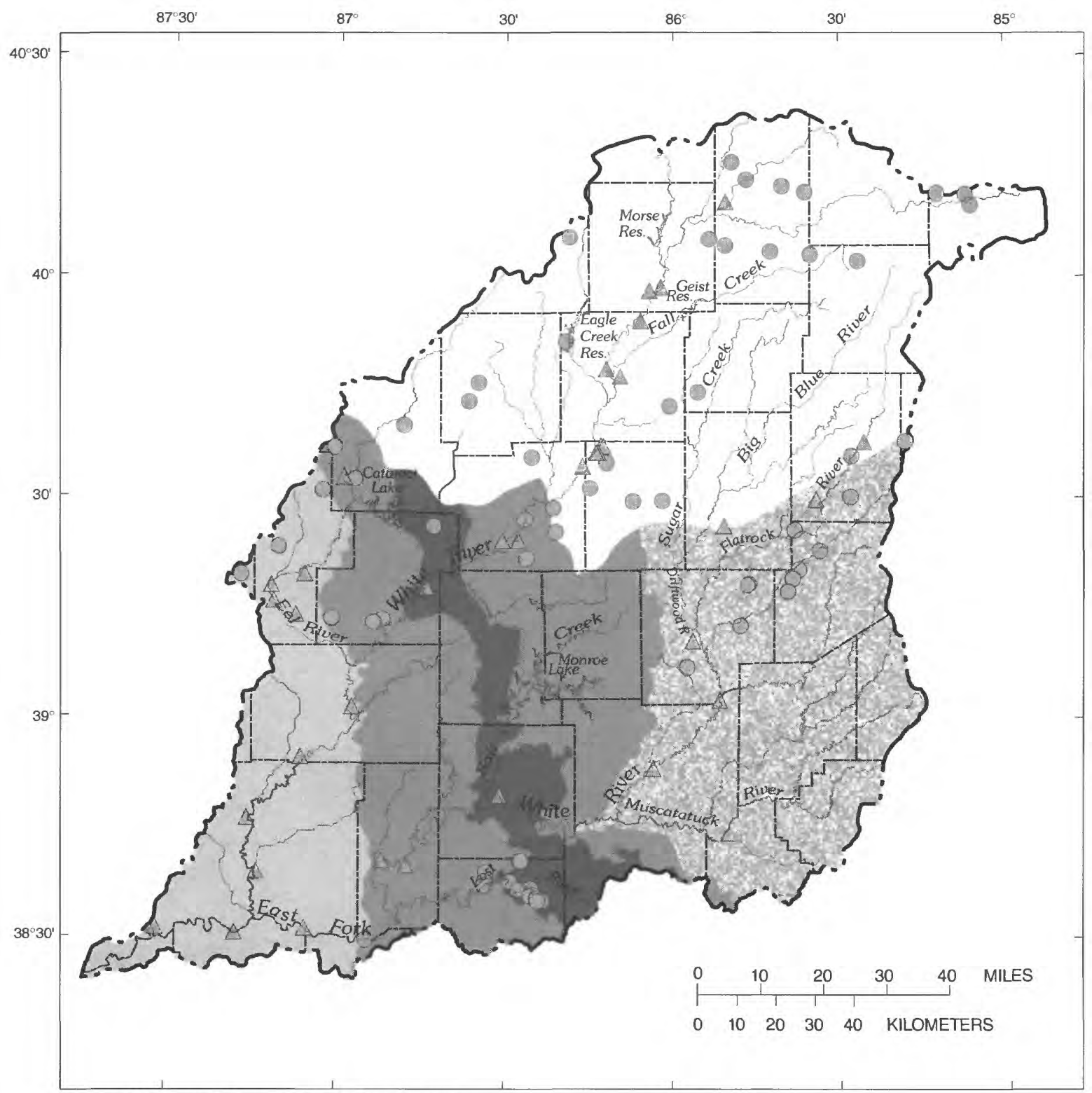

Base from U.S. Geological Survey digital data, 1:100,000, 1983

Albers Equal-Area projection

Standard parallels $29^{\circ} 30^{\prime}$ and $45^{\circ} 30^{\prime}$, central meridian -86

\section{EXPLANATION}

\section{SAMPLING SITES}

(1) Ground-water-quality sampling site

$\triangle$ Ground-water-quality sampling site located in the fluvial deposits hydrogeomorphic region

\section{HYDROGEOMORPHIC REGIONS}

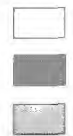
Till plain
Bedrock uplands
Bedrock lowland and plain

Glacial lowland

\section{-.. White River Basin boundary} County boundary

Figure 9. Location of ground-water-quality sampling sites in the White River Basin, Indiana, 1987-91. 

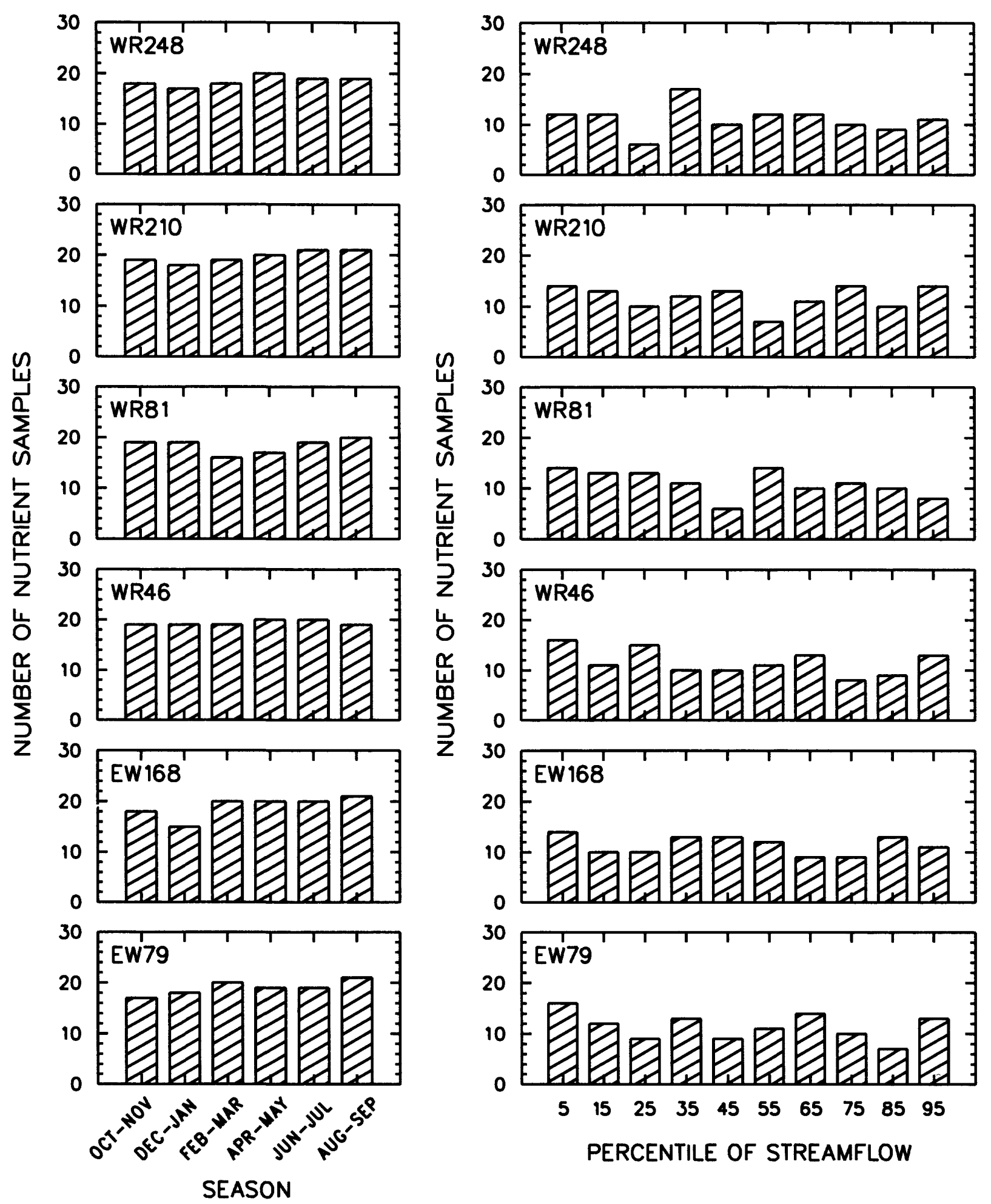

Figure 10. Number of nutrient samples by season and by percentile of streamflow at selected surface-water-quality monitoring sites in the White River Basin, Indiana, 1981-90 water years. 
It is more difficult to obtain samples throughout the range of streamflow, particularly at sites with small drainage areas where flows rise, peak, and recede rapidly. Samples collected at IDEM monitoring sites at or near USGS streamflowgaging stations were well distributed over the range of streamflow. The distribution of samples collected at sites WR248, WR210, WR81, WR46, EW 168, and EW79 by percentile of streamflow (fig. 10) was typical of the other IDEM monitoring sites that have streamflow data. Samples collected at IDEM monitoring sites on large rivers that lack streamflow data probably were distributed similarly, with respect to streamflow, to those discussed above because they also were sampled monthly. Samples collected at sites on small rivers and streams probably have fewer samples collected during high streamflows.

\section{Distribution of Ground-Water Samples by Aquifer Type, Hydrogeomorphic Region, and Well Type}

Aquifers are geologic materials capable of yielding usable quantities of water to wells. Knowledge of the type of aquifer is critical in assessing ground-water quality because aquifers differ in hydraulic characteristics and susceptibility to contaminants. Four types of aquifers were evaluated in this assessment - till, outwash, bedrock, and karst (limestone that contains solution features). Wells in till aquifers obtain water from buried lenses of sand and gravel in less permeable clayey or loamy till. Till aquifers usually are confined, which means that the buried sand and gravel aquifer occurs at depth under pressure and that the water level in a well would rise above the top of the sand lens that produces the water and into the till that confines the aquifer (Freeze and Cherry, 1979, p. 48). Wells in outwash aquifers obtain water from large deposits of permeable sand and gravel, usually near streams. Outwash aquifers commonly are unconfined near the stream but may be confined elsewhere by overlying deposits. Wells in bedrock aquifers obtain water from consolidated deposits, generally at depths greater than the other aquifer types. Bedrock aquifers generally are confined. Wells in karst aquifers obtain water from the Blue River Group and the Sanders Group of the Mississippian Period. These rocks form sinkholes at land surface and other solution features at depth. Most wells used in this assessment obtain water from outwash or bedrock aquifers (fig. 11), the most productive aquifer types in the basin (Fenelon and Greeman, 1994, p. 153; Hoover and Durbin, 1994, p. 132).

Most of the types of aquifers are located primarily in only one of the hydrogeomorphic regions used in this assessment. For example, 28 of 34 wells in outwash aquifers are in the fluvial deposits region. Similarly, most of the wells in till aquifers are in or near the boundary of the till plain region and most of the wells in karst aquifers are in or near the boundary of the karst plain region. However, wells in bedrock aquifers were approximately equally distributed among the till plain, bedrock lowland and plain, bedrock uplands, and karst plain regions. Few wells were in the glacial lowland region. Because of the limited number of wells used in this assessment, the effects of hydrogeomorphic region, within aquifer type, on ground-water quality could not be analyzed and analysis of the effects of hydrogeomorphic region, without consideration of aquifer type, was inappropriate. The effects of aquifer type on ground-water quality were analyzed; results for till, outwash, and karst aquifers probably are representative of ground-water quality in the till plain, fluvial deposits, and karst plain hydrogeomorphic regions, respectively. Results for bedrock aquifers are a composite of a variety of regions and probably are not representative of ground-water quality in the bedrock uplands hydrogeomorphic region.

Knowledge of the type of well from which water samples were collected is helpful in assessing ground-water quality because wells differ in construction, development, yield, and pumping characteristics. Four types of wells, classified by the use of the water, were used in this assessment-community public water-supply wells, noncommunity public water-supply wells, domestic wells, and observation wells. Community public water-supply wells provide water to municipalities or to people in rural areas served by 

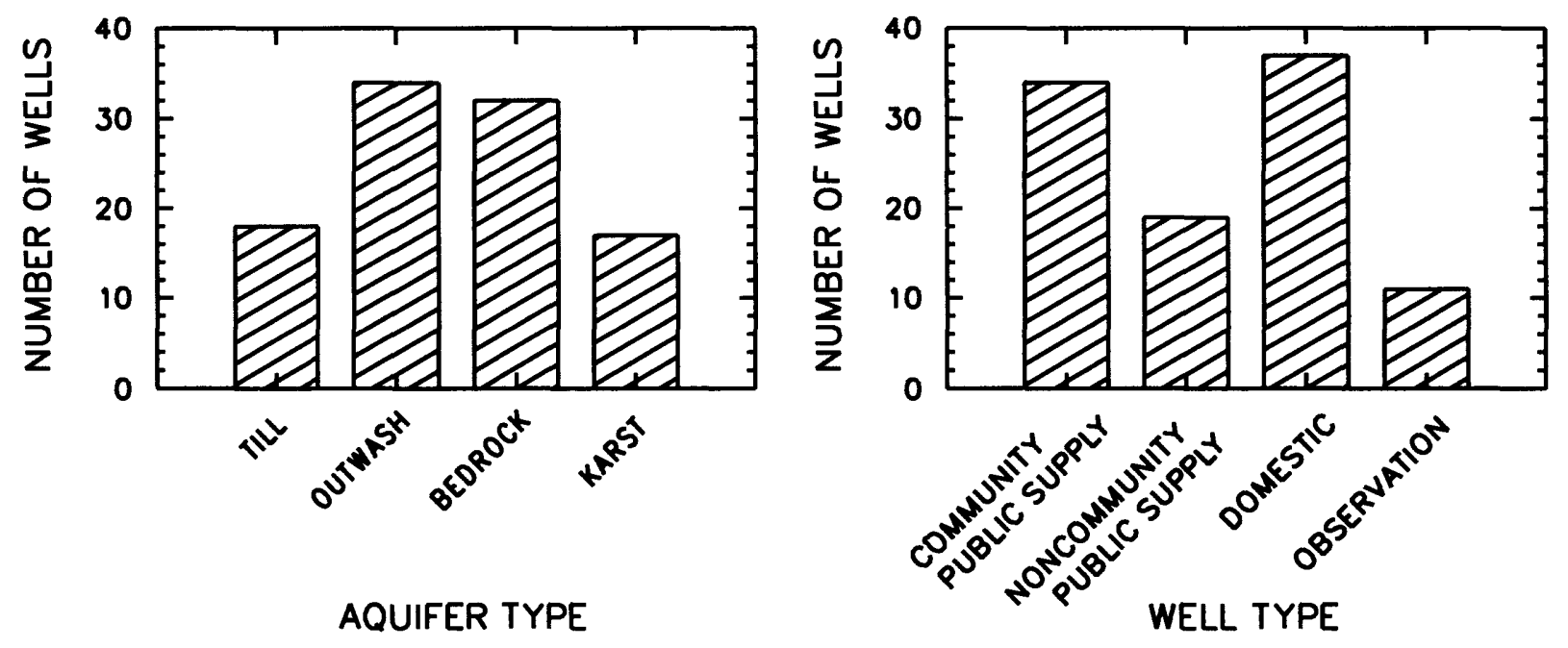

Figure 11. Number of wells by aquifer type and well type, White River Basin, Indiana, 1987-91. 
community public water-supply systems. These wells are pumped at high rates and are in highly productive aquifers. Noncommunity public watersupply wells provide water to churches, schools, restaurants, mobile-home parks, and similarly sized public establishments. Domestic wells provide water to individual home owners. Observation wells are not used for water supply but are used to monitor water quality or water levels and are pumped infrequently. Water-supply wells often have long screens or open holes and may obtain water from a series of aquifers. Aquifer types for water-supply wells used in this assessment were assigned on the basis of well logs and other geologic information and identify the main aquifer supplying water to the well. Minor amounts of water, however, also may be obtained from different aquifer types. Most of the wells sampled for nutrients were used for public and domestic water supply (fig. 11).

\section{Relation of Nutrient Concentrations and Loads to Natural and Human Factors}

A variety of natural and human factors affect water quality. These include the amount and intensity of precipitation; amount and timing of recharge and runoff; temperature; evapotranspiration; land- and water-management practices and use; waste-disposal practices; growth of vegetation and crops; algal photosynthesis and metabolism; and the metabolic processes of bacteria in soil, water, sediment, and aquifers. Most of these factors are complexly interrelated, and the effect of one factor on water quality may be masked, diminished, or enhanced by other factors. This section identifies important factors and hydrologic processes that affect nutrient concentrations and loads.

\section{Surface Water}

The major factors affecting nutrient concentrations in surface water investigated in this assessment are land use, season, streamflow, and hydrogeomorphic region.
Relation of Nutrient Concentrations to Land Use

Spatial variations in nutrient concentrations in the White River Basin were affected by the location of the monitoring site with respect to point and nonpoint sources of nutrients associated with urban and agricultural land uses, and by dilution, nitrification, nutrient uptake by algae, and nutrient adsorption to stream-bottom sediments.

Concentrations of ammonia increased markedly at monitoring sites downstream from the major urban areas on the White River (fig. 12). High concentrations of ammonia downstream from Muncie (site WR309), Anderson (site WR279), and Indianapolis (site WR210) probably were caused by discharges from municipal sewagetreatment plants (Metcalf \& Eddy, Inc., 1979, p. 704-707; Crumpton and Isenhart, 1987) and by discharges from combined-sewer overflows and urban runoff in these cities (Indiana Department of Environmental Management, 1990, p. 144-154; Martin, 1995, p. 85, 90). Median concentrations of ammonia at sites WR309 (0.2 mg/L), WR279 $(0.3 \mathrm{mg} / \mathrm{L})$, and WR210 (0.3 mg/L) were 0.15 to $0.25 \mathrm{mg} / \mathrm{L}$ higher than the median concentrations at monitoring sites upstream from the urban areas. Most of the high concentrations of ammonia at site WR210 occurred during 1980-82, prior to completion of improvements to sewage-treatment plants in Indianapolis (Crawford and Wangsness, 1991a, b).

Concentrations of ammonia were high at monitoring sites downstream from Indianapolis but gradually decreased in the downstream reach of the White River (sites WR162, WR81, and WR46), probably because of dilution, nitrification, algal and bacterial uptake of ammonia, adsorption to stream-bottom sediments, and volatilization (Wetzel, 1975, p. 197, 213; Crumpton and Isenhart, 1987). Algae prefer ammonia over nitrate as a nutrient (Brezonik, 1973, p. 11; Crumpton and Isenhart, 1987, p. 821) but can use either for growth. Volatilization of ammonia probably is a significant process in the White River during 


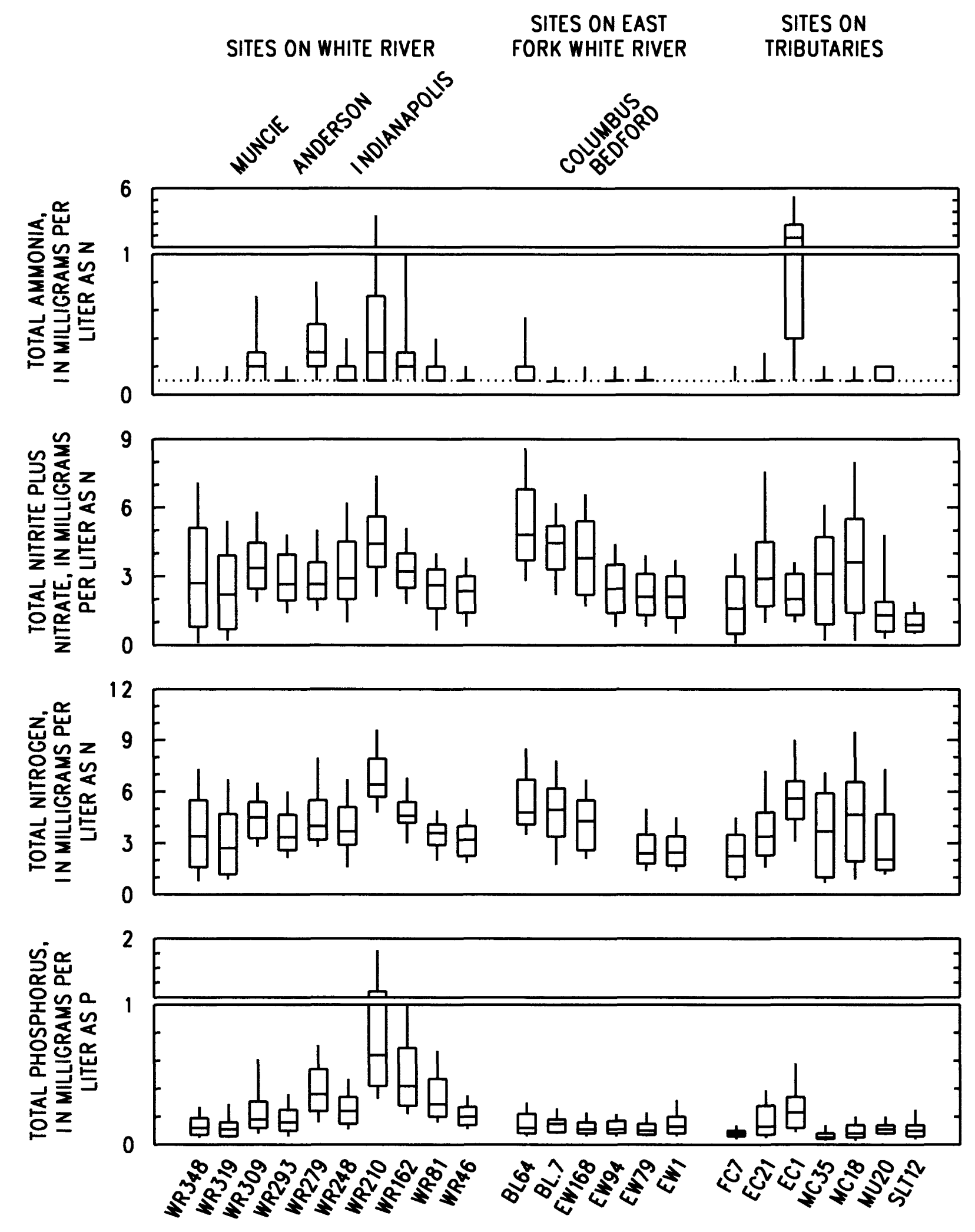

Figure 12. Nutrient concentrations at surface-water-quality monitoring sites in the White River Basin. Indiana, 1981-90 water years. (Dashed line is the detection limit for ammonia.) 
summer low-flow conditions. Water temperature and $\mathrm{pH}$ in the White River near Indianapolis during summer low flow commonly are greater than $28^{\circ} \mathrm{C}$ and 8.2, respectively (Martin and Craig, 1990). With such conditions, or higher values of temperature and $\mathrm{pH}, 10$ percent or more of the ammonia dissolved in water is un-ionized and susceptible to volatilization (Thurston and others, 1979; Sommers, 1985). These conditions of temperature and $\mathrm{pH}$ also are optimum for nitrification (National Research Council, 1978, p. 37).

Concentrations of ammonia were relatively high at two (sites BL64 and EC1) of five monitoring sites downstream from small municipal sewage-treatment plants (sites BL64, BL.7, EW79, EC21, and EC1). Differences in ammonia concentrations at these sites probably were caused by differences in the quality and quantity of the treatment-plant discharge, the amount of streamflow available for dilution, and travel time from the point of discharge to the monitoring site. Long times of travel would provide more opportunity for ammonia to be converted to nitrate or be taken up by aquatic plants.

Median concentrations of ammonia were less than the detection limit $(<0.1 \mathrm{mg} / \mathrm{L})$ at monitoring sites in the headwaters of the White River (sites WR348 and WR319), in the middle and downstream reaches of the East Fork White River (sites BL.7, EW168, EW94, and EW79), downstream from the confluence of the east and west forks (site WR46), and in several of the tributaries (sites FC7, MC35, MC18, and SLT12). Although median concentrations of ammonia were less than detection limits, infrequent, high concentrations of ammonia may have been measured at these sites. Boxplots used in this assessment show only the central 80 percent of the measurements and provide information on typical water-quality conditions. The highest 10 percent and lowest 10 percent of the measurements are not shown. High concentrations of ammonia, nitrate, total nitrogen, and total phosphorus are shown in timeseries plots in figures 16-19.
Concentrations of ammonia were compared to Indiana water-quality criteria for maximum ammonia concentrations and for 24-hour average ammonia concentrations (Indiana Department of Environmental Management, 1995, p. 14-18). Water-quality criteria for ammonia are a complex function of ammonia concentration, water temperature, and $\mathrm{pH}$ (U.S. Environmental Protection Agency, 1986, p. 31-40; Indiana Department of Environmental Management, 1995, p. 14-18). Sites WR348 and WR309 lacked water-temperature data to calculate the ammonia criteria. Concentrations of ammonia at three monitoring sites exceeded the maximum ammonia criteria. The monitoring sites, the number of measurements that exceeded the criteria, and the ratio or range of the ratio of the measured ammonia concentration to the ammonia criteria for measurements that exceeded the criteria follow: site WR210 $(1,1.40)$, site WR81 $(1,1.04)$, and site ECl $(6,1.03-4.94)$.

Concentrations of ammonia at 10 monitoring sites exceeded the 24-hour average ammonia criteria. The 24-hour average criteria, however, was calculated on the basis of only one sample per 24-hour period. Short-term variations in ammonia concentration, water temperature, and $\mathrm{pH}$ were not measured and the effects of shortterm variations in ammonia concentration, water temperature, and $\mathrm{pH}$ on the 24-hour average ammonia criteria are not known. The comparison of ammonia concentrations from a single sample to the 24-hour average criteria was done to identify sites that could have exceeded the 24 -hour criteria, on the basis of available data. The monitoring sites, the number of measurements that exceeded the criteria, and the ratio or range of the ratio of the measured ammonia concentration to the ammonia criteria for measurements that exceeded the criteria follow: site WR279 (3, 1.26-1.49), site WR248 (3, 1.86-3.36), site WR210 (14, 1.23-10.3), site WR162 $(9,1.09-3.33)$, site WR81 $(6,1.28-7.61)$, site WR46 (3, 1.00-1.66), site EW94 $(1,1.12)$, site EC21 (2, 2.19-3.17), site EC1 $(59,1.04-36.3)$, and site $\mathrm{MC} 35(2,1.27-5.91)$. 
Median concentrations of nitrate increased approximately 1 to $1.5 \mathrm{mg} / \mathrm{L}$ downstream from Muncie (site WR309) and Indianapolis (site WR210) but showed no increase downstream from Anderson (site WR279) (fig. 12). Increased concentrations of nitrate downstream from Muncie and Indianapolis probably were caused by the discharge of nitrate from the sewage-treatment plants and by the instream nitrification of ammonia and organic nitrogen discharged from the sewage-treatment plants. The reason for the lack of an increase in median nitrate concentrations downstream from Anderson is not known but may be related to the discharge of treated sewage that is low in nitrate, river conditions that inhibit nitrification, uptake of nitrate by algae, or dilution.

The highest median nitrate concentration in the White River was $4.4 \mathrm{mg} / \mathrm{L}$ at site WR210, downstream from Indianapolis. Concentrations of nitrate decreased steadily downstream from site WR210 (fig. 12). Decreased concentrations of nitrate in this reach probably were caused by dilution by surface and ground water and by the uptake of nitrate by algae and other aquatic vegetation. The highest median nitrate concentration in the East Fork White River was $4.8 \mathrm{mg} / \mathrm{L}$ at site BL64, downstream from New Castle. Median concentrations of nitrate also decreased downstream in the East Fork White River (fig. 12); dilution and algal uptake probably caused this pattern of decrease as well. Concentrations of nitrate in the downstream reach of the east fork were less than those in the downstream reach of the west fork, probably because of the much smaller volumes of municipal effluent discharged to the east fork (fig. 6). The median concentration below the confluence of the east and west forks (site WR46) was $2.35 \mathrm{mg} / \mathrm{L}$. This concentration is less than that at site WR81 (2.6 mg/L) but more than that at site EW1 $(2.1 \mathrm{mg} / \mathrm{L})$ and reflects the mixing of water from the two forks.

Median nitrate concentrations at monitoring sites in the White River Basin generally were 2 to $3 \mathrm{mg} / \mathrm{L}$ or greater-much higher than those at most other monitoring sites in the United States (fig. 13) but similar to agricultural sites in northwestern Ohio (Baker, 1984, p. 3). Nitrate concentrations in the small, agricultural basins (sites WR348 and MC35) were more variable than those at other sites, probably because streamflow was more variable in the small basins and because of the lack of a steady, point-source input of nitrogen. Median concentrations of nitrate were lowest at sites SLT12 (0.9 mg/L), MU20 (1.3 mg/L), and FC7 $(1.6 \mathrm{mg} / \mathrm{L})$. Low concentrations at sites SLT12 and FC7 probably were caused by low concentrations in the water-supply reservoirs upstream from these sites (fig. 5). In addition, Salt Creek at site SLT12 drains a large area of forest. Forested areas typically have less nitrate in streamflow than agricultural areas (National Research Council, 1978, p. 116, 118, 229; Smith and others, 1993, p. 123), probably because fertilizers typically are not applied to forests and because these forests are accumulating biomass and, as a result, nutrients (Vitousek, 1977, p. 81-83). Nitrate concentrations were least variable at site SLT12, probably because water released from Lake Monroe had a low and constant nitrate concentration and because the reservoir contained and mixed runoff with the reservoir water.

Concentrations of nitrate at eight monitoring sites equaled or exceeded the Maximum Contaminant Level $(10 \mathrm{mg} / \mathrm{L})$ of the regulations for treated drinking water (U.S. Environmental Protection Agency, 1986) promulgated for the Safe Drinking Water Act. The monitoring sites, the number of measurements equal to or greater than $10 \mathrm{mg} / \mathrm{L}$, and the nitrate concentration or range of nitrate concentrations equal to or greater than $10 \mathrm{mg} / \mathrm{L}$ follow: site WR348 $(2,11-12 \mathrm{mg} / \mathrm{L})$, site WR210 $(5,10-14 \mathrm{mg} / \mathrm{L})$, site WR46 (1, $11 \mathrm{mg} / \mathrm{L})$, site BL64 $(2,12-13 \mathrm{mg} / \mathrm{L})$, site EC1 $(1,15 \mathrm{mg} / \mathrm{L})$, site $\operatorname{MC} 35(1,10.7 \mathrm{mg} / \mathrm{L})$, site MC18 (1, $10.4 \mathrm{mg} / \mathrm{L})$, and site MU20 $(1,10 \mathrm{mg} / \mathrm{L})$. The high concentrations of nitrate at sites WR210, BL64, and EC1 occurred during late summer and autumn and probably were attributable to point-source discharges during periods of low streamflow. The high concentrations of nitrate at sites WR348, MC35, MC18, and MU20 occurred during spring 

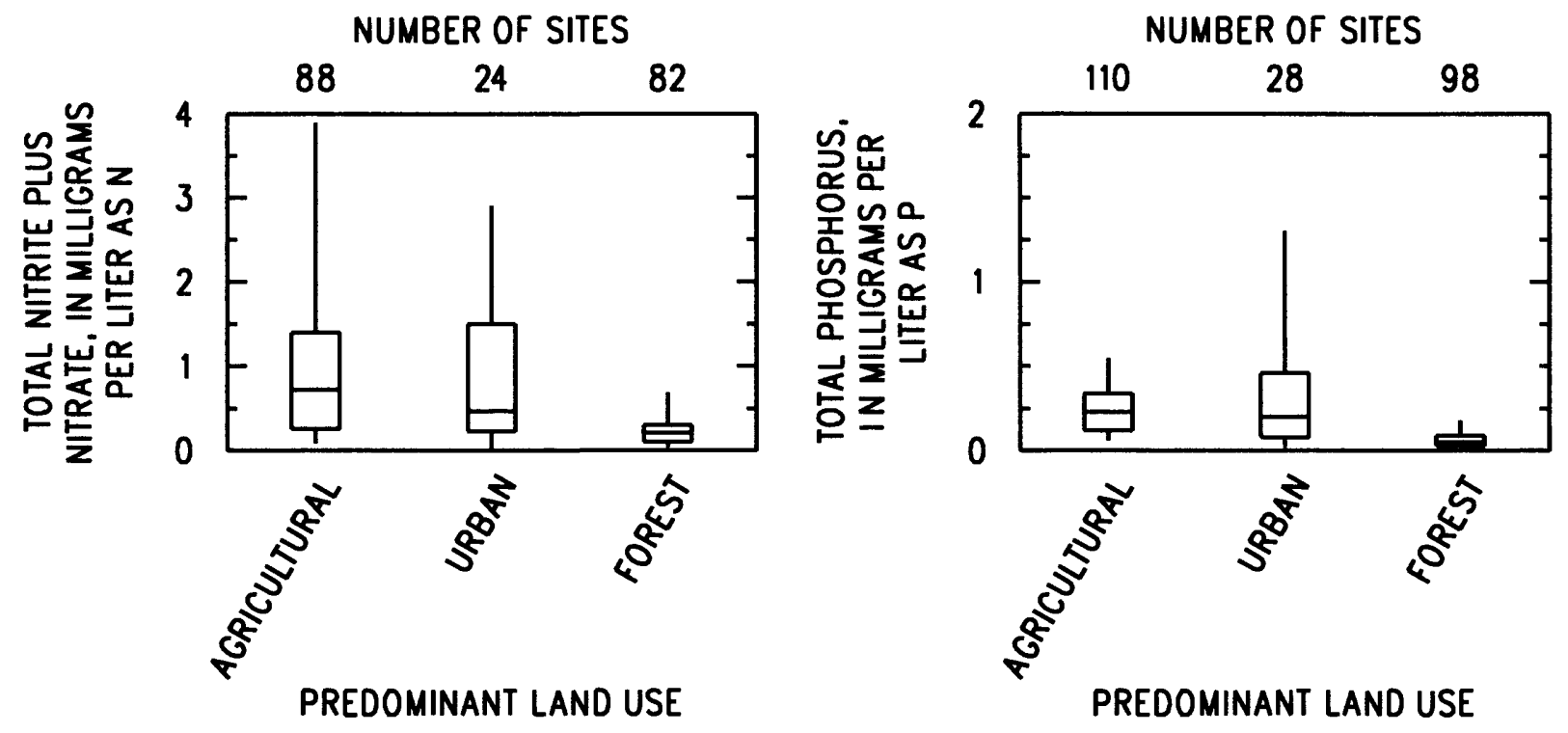

Figure 13. Median concentrations of nutrients at national reference sites, 1980-89 water years. (Drainage areas of most sites were greater than 1.000 square miles. Data are from Smith and others, 1993, p. 123-125.) 
and summer and may have been attributable to runoff from farm fields or feedlots. Concentrations of nitrate sometimes exceeded $10 \mathrm{mg} / \mathrm{L}$ in small, agricultural streams during March and May in Indiana (Scribner and others, 1993, p. 45). The high concentrations during May could have been associated with runoff from recently fertilized fields, but the high concentrations during March occurred during low flow prior to planting and probably indicate transport of nitrate from sources other than recently applied fertilizers.

Spatial patterns of total nitrogen were similar to those for nitrate because nitrate composed approximately 65 to 80 percent of the total nitrogen at most monitoring sites. Median concentrations of organic nitrogen (1981-85 water years) were 0.4 to $0.6 \mathrm{mg} / \mathrm{L}$ at most sites, and organic nitrogen composed approximately 15 to 25 percent of the total nitrogen at most sites. Median concentrations of organic nitrogen were greater than $0.6 \mathrm{mg} / \mathrm{L}$ at sites on the White River downstream from sewage-treatment plants and in the downstream reach of the White River. Higher concentrations at these monitoring sites probably were caused by the discharge of organic nitrogen from sewage-treatment plants and by organic nitrogen contained in the cells of algae (phytoplankton) suspended in the water samples.

Concentrations of total phosphorus were similar to those for ammonia in terms of the patterns of increases and decreases among sites and the variability at a site (fig. 12). Median concentrations of total phosphorus downstream from Muncie (site WR309), Anderson (site WR279), and Indianapolis (site WR210) were 0.07, 0.2, and $0.4 \mathrm{mg} / \mathrm{L}$ higher, respectively, than the median concentrations at the monitoring sites upstream from these cities. Increased concentrations of total phosphorus probably were caused by the discharge of treated sewage, urban runoff, or other discharges in these cities. The largest median total phosphorus concentration was $0.64 \mathrm{mg} / \mathrm{L}$ at site WR210, downstream from Indianapolis. Concentrations decreased downstream from site WR210, probably because of dilution; uptake of dissolved, inorganic phosphorus (primarily phosphate) by aquatic plants and phytoplankton; and adsorption of dissolved, inorganic phosphorus to streambed sediments (Johnson and others, 1976, p. 153; Baker, 1984, p. 6; Brown and others, undated, p. 62-67). Median concentrations of total phosphorus ranged from 0.05 to $0.13 \mathrm{mg} / \mathrm{L}$ at monitoring sites upstream from sewage-treatment plants in the headwaters of the White River (sites WR348 and WR319), on the East Fork White River, and on tributaries upstream from sewagetreatment plants (sites FC7, MC35, and MC18). Concentrations of total phosphorus at these sites were lower than those at other agricultural sites in the United States (fig. 13). Median concentrations of total phosphorus ranged from 0.13 to $0.64 \mathrm{mg} / \mathrm{L}$ at sites affected by the discharge of treated sewage (sites WR309-WR81, EC21, and EC1) and were similar to or higher than those at other agricultural or urban sites in the United States (Smith and others, 1993, p. 125).

\section{Relation of Nutrient Concentrations to Season and Streamflow}

Some of the variations in nutrient concentrations in streams and rivers are related to the time of year and the rate of streamflow during which the sample was collected. The effects of season and streamflow are closely related in the White River Basin. The graphs in this section do not show the relations of nutrient concentrations to season and streamflow for all monitoring sites. Examples of these relations are shown in graphs for six monitoring sites on the White and East Fork White Rivers.

Median streamflow during the collection of water-quality samples was greatest during February/March or April/May. (Streamflow data were available for 11 monitoring sites.) Generally, these are months with high groundwater tables, high base-flow rates, large amounts of precipitation and runoff, and low rates of evapotranspiration. During these months, soils typically are wet (or frozen), and rainfall readily runs off. Median streamflow was lowest during August/September at the three sites upstream from Indianapolis on the White River but was lowest during October/November for the other eight sites. 
Generally, these are months with low groundwater tables, low rates of base flow, small amounts of precipitation and runoff, dry soils, and high rates of evapotranspiration.

Median concentrations of ammonia were greatest during December/January at site EC21 and the eight downstream-most monitoring sites on the White River (figs. 5, 14). (Median ammonia concentrations were less than the detection limit for all seasons at sites WR348 and WR319, but the 75-percentile concentrations were greatest during December/January.) High concentrations of ammonia during December/January probably were caused by cold river temperatures, which decreased instream nitrification of ammonia (the biochemical conversion of ammonia to nitrite, and nitrite to nitrate), decreased volatilization of ammonia, and reduced biological uptake of ammonia by algae and other aquatic plants. High concentrations of ammonia during December/January also probably were caused by increased concentrations of ammonia in the discharge from sewage-treatment plants. Cold water temperatures reduce the efficiency of treatment (nitrification) in sewage-treatment plants (John Barr, Indianapolis Department of Public Works, oral commun., March 1994).

Median concentrations of ammonia generally were lowest during the growing season (April-September) at site EC21 and the eight downstream-most monitoring sites on the White River. Warm river temperatures during the growing season increased nitrification, volatilization, and uptake by algae and other aquatic plants (Crumpton and Isenhart, 1987). The seasons of maximum and minimum concentrations of ammonia at the other monitoring sites were much more variable than those in the White River (fig. 14). Median ammonia concentrations were highest during June/July at sites EW94 and EW79 (the 75th percentile was greatest during June/July at site EW1). High concentrations of ammonia during this season might have been caused by runoff of commercial fertilizer or animal wastes applied to farm fields or by discharges from upstream sewage-treatment plants (site EW79).
Ammonia concentrations were negatively correlated to streamflow at sites WR46 and EW79 (fig. 15), whereas ammonia at the other nine monitoring sites with streamflow data was not correlated to streamflow. A negative relation between a water-quality constituent and streamflow often results from dilution of a point source of the constituent. It is not clear why site WR46 exhibits a negative relation between ammonia and streamflow whereas sites WR210 and WR81, which are much closer to the major point sources of ammonia (sewage-treatment plants), do not exhibit statistically significant negative relations (although the slope of the smooth for site WR81 shows a negative relation). The negative relation between ammonia and streamflow at site EW79 supports the hypothesis that upstream point sources may be affecting ammonia concentrations at this site.

Median concentrations of nitrate were greatest during February/March (nine sites), December/January (five sites), or April/May (five sites) (fig. 14). High concentrations of nitrate during winter and spring were consistent with seasonal patterns observed in the Midwestern United States (Goolsby and Battaglin, 1993, p. 17) and probably were caused by the transport of nitrate that had accumulated in the soil. Nitrate is produced by nitrification of organic nitrogen and ammonia in soil, fertilizer, and animal wastes, and may accumulate because of a lack of uptake by dormant vegetation (Likens and others, 1977, p. 48) or by a lack of transport to surface and ground water during dry periods (Randall and others, 1993, p. 684). Winter and spring rains move nitrate through the soil to rising water tables, and field tile drains transport nitrate in soil water and high water tables to streams (National Research Council, 1978, p. 111). Median concentrations of nitrate were lowest during August/September (16 sites) or October/November (6 sites) and were approximately three times less than those during winter and spring (fig. 14). Low concentrations of nitrate during these seasons probably were caused by the uptake of nitrate in 

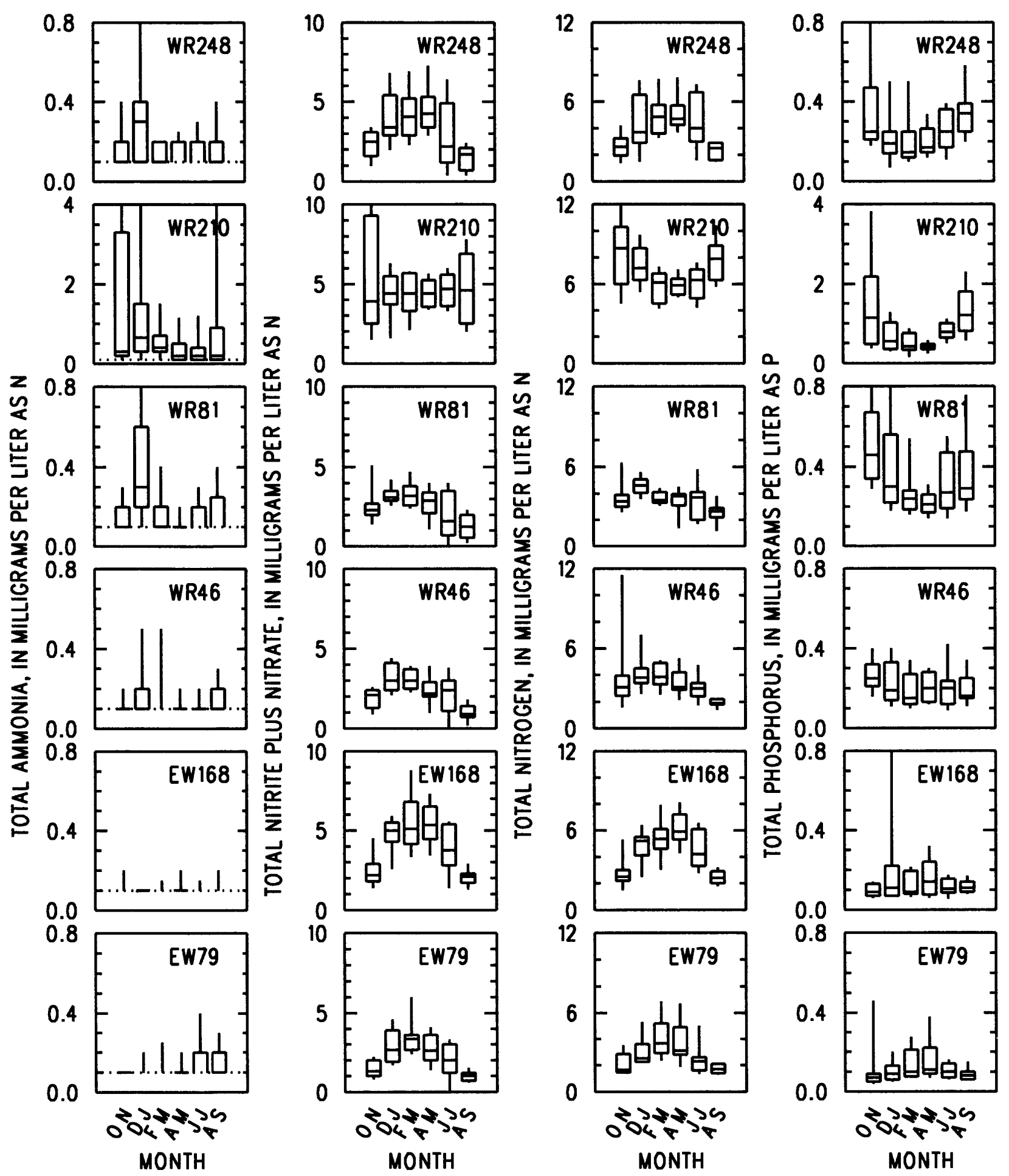

Figure 14. Seasonal variations in nutrient concentrations at selected surface-waterquality monitoring sites in the White River Basin, Indiana, 1981-90 water years. (Nintieth percentile concentrations were truncated at the maximum concentration shown, where needed, to allow better resolution of seasonal median concentrations. Dashed line is the detection limit for ammonia.) 
soils and streams by terrestrial and aquatic vegetation and by reduced nitrate transport because of high evapotranspiration and low precipitation, soil moisture, and ground-water levels.

Nitrate was positively correlated to streamflow at 10 of 11 monitoring sites with streamflow data (fig. 15). Increased nitrate concentrations at high rates of streamflow indicate that nitrate is primarily a nonpoint-source pollutant. During storms, nitrate that has accumulated on the land surface and in the soil is transported to streams by water flowing overland and through soils and by shallow ground water. At extremely high rates of streamflow, concentrations of nitrate are lower than those at high rates of flow (fig. 15). Decreased concentrations at the highest rates of streamflow indicate that at some point in the runoff process, sources of nitrate for transport to streams become depleted and further rainfall and runoff diluted instream nitrate concentrations. At site WR210, nitrate was negatively correlated to streamflow. This relation between nitrate and streamflow indicates that runoff diluted point sources of nitrate from municipal sewagetreatment plants upstream from this site.

Seasonal variations of total nitrogen were similar to those of nitrate because nitrate typically composed about 65 to 80 percent of the total nitrogen at most monitoring sites. Median concentrations were highest during December through May at all sites and lowest during August through November at all but one site (fig. 14). Statistically significant relations between total nitrogen and streamflow were the same as those between nitrate and streamflow, except at WR81 and EW94. At WR81 and EW94, no statistically significant correlation between total nitrogen and streamflow was determined.

Median concentrations of total phosphorus were highest during August through November (15 of 23 sites). Most of these monitoring sites were on the White River and tributaries (sites on the East Fork White River exhibited a different seasonal pattern). Low streamflows are common during August through November, and high concentrations of total phosphorus during these months probably were caused by diminished dilution of sewage effluent at sites affected by point-source discharges (fig. 14). Median concentrations of total phosphorus were lowest during February through May (17 of 23 sites). Low concentrations during this season probably were caused by increased dilution of sewage effluent by high rates of base flow, and by increased uptake of inorganic phosphorus by aquatic plants during April and May.

Seasonal patterns of total phosphorus at the four downstream-most monitoring sites on the East Fork White River were different from those on the White River (fig. 14). Median total phosphorus was highest during April/May and lowest during October through January. Phosphorus is tightly bound in soils (Brady, 1974, p. 456-471), and concentrations of phosphorus on fine, eroded soil particles are as much as three times higher than those in bulk, uneroded soil (Brady, 1974, p. 241-242). High concentrations during spring may have been caused by soil erosion from recently tilled farm fields. Low concentrations of total phosphorus during autumn in the East Fork White River probably were caused by low streamflow and low rates of erosion during this season and by the lack of urban point sources of phosphorus. Some of the tributaries unaffected by point sources had high concentrations of phosphorus during autumn. The reasons for the differences in phosphorus concentrations between tributaries unaffected by point sources and sites on the East Fork White River during autumn are not known but may relate to a greater sediment storage capacity or a greater dilution capacity of the East Fork White River as compared to small tributaries.

Total phosphorus was significantly correlated to streamflow at seven monitoring sites. Concentrations of total phosphorus were positively correlated with streamflow at sites WR319, EW168, EW94, and EW79 (fig. 15). Increased concentrations of total phosphorus during runoff indicate that total phosphorus is a nonpointsource pollutant at these sites. The relation of total phosphorus and streamflow in the East Fork White River was opposite that of most sites downstream from urban point sources in the White River. 


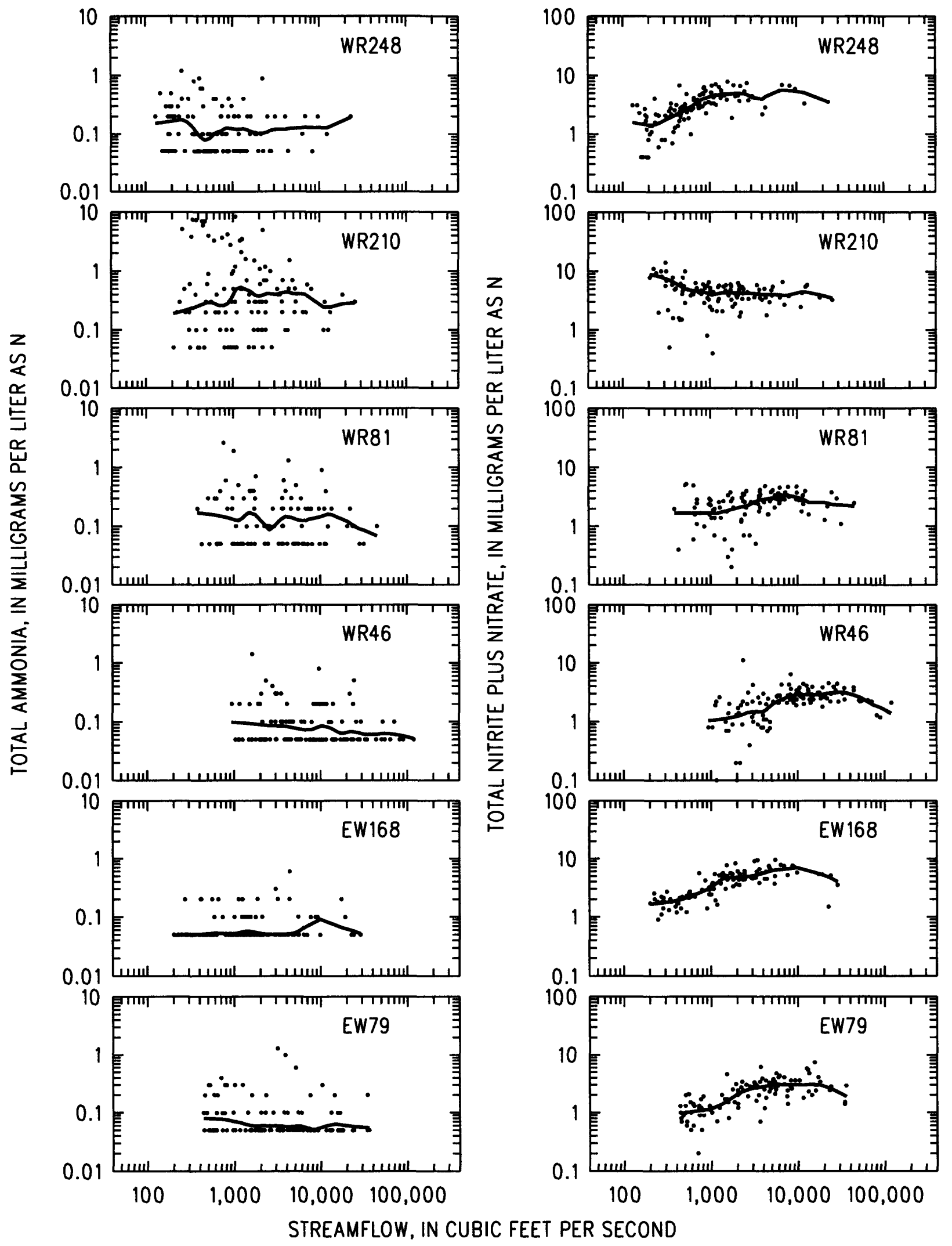

Figure 15. Relation of nutrient concentrations to streamflow at selected surface-waterquality monitoring sites in the White River Basin, Indiana, 1981-90 water years. (The line in the scatterplot is a smooth that shows the general relation between concentration and streamflow.) 


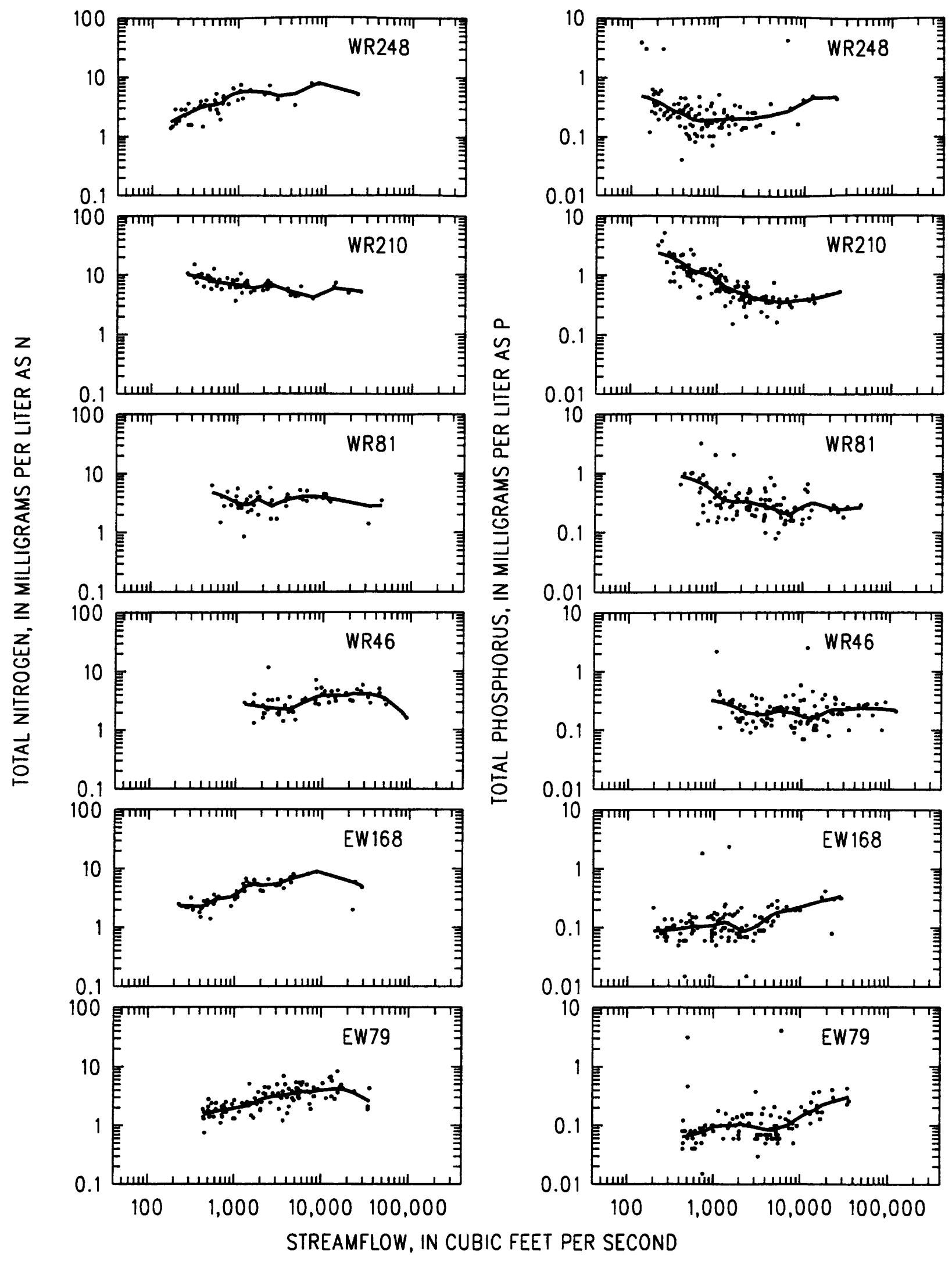

Figure 15. Relation of nutrient concentrations to streamflow at selected surface-waterquality monitoring sites in the White River Basin, Indiana, 1981-90 water years. -Continued. 
Concentrations of total phosphorus decreased with increased flow at sites WR248, WR210, and WR81 (fig. 15). Increased streamflow diluted phosphorus from point sources of treated sewage upstream from these sites. Even though dilution is the dominant process at these sites, phosphorus increases at the highest rates of streamflow at sites WR248 and WR210. This increase indicates that nonpoint sources of phosphorus are an important source of phosphorus during high rates of streamflow.

\section{Time Trends in Nutrient Concentrations}

Water-quality data collected at selected monitoring sites in the White River Basin were examined to determine if concentrations of nutrients appeared to be increasing or decreasing during the study period (water years 1981-90). Visual inspection of time-series plots of the data (figs. 16-19) and two nonparametric statistical test procedures (fig. 20, tables 2-4) were used in this study for exploratory trend analysis. Trend analyses discussed in this section are considered exploratory because the rigorous statistical analysis needed to confirm trends and the causes of trends (McLeod and others, 1991, p. 174) was beyond the scope of this study.

Concentrations of ammonia have increased at sites WR248, BL64, MU20, and SLT12 but have decreased at sites WR210, WR162, EC21, and EC1 (figs. 16 and 20, table 2). Increased concentrations of ammonia at sites WR248, BL64, MU20, and SLT12 may have been related to increased urbanization upstream from these monitoring sites and associated increases in treated sewage and urban runoff. The growth of suburbs north of Indianapolis in Hamilton County has required the expansion of the Carmel sewage-treatment plant from 3-Mgal/d design capacity in the early 1980's to $12-\mathrm{Mgal} / \mathrm{d}$ design capacity in 1995 (Ed Wolfe, Carmel Sewage Treatment Plant, oral commun., May 1995). Decreased concentrations of ammonia at site WR210 have resulted from improvements completed in 1983 to the Indianapolis sewagetreatment plants (Crawford and Wangsness, 1991a, b). Median concentrations of ammonia in the White River downstream from Indianapolis decreased from $2.0 \mathrm{mg} / \mathrm{L}$ before improvements were made to $0.24 \mathrm{mg} / \mathrm{L}$ after improvements were made (Crawford and Wangsness, 1991a, p. 17). Decreased concentrations of ammonia at site WR162 also probably were caused by improvements to the Indianapolis sewage-treatment plants. Some of the high concentrations of ammonia measured at sites WR81 and WR46 during 1980 83 appear to have been related to high concentrations discharged from Indianapolis (fig. 16). Since the improvements to the Indianapolis sewagetreatment plants, relatively few high concentrations of ammonia were measured at sites WR81 and WR46. Decreased concentrations of ammonia at sites EC21 and EC1 also may have been related to improvements in sewage treatment, although the amount of decrease was much less than that measured in the White River downstream from Indianapolis.

Streamflow-adjusted concentrations of ammonia also have decreased at site WR210 and indicate that the decreasing trend in ammonia was caused by improvements in sewage treatment rather than by a particular sequence of streamflows. Streamflow-adjusted concentrations of ammonia at site WR248 indicate a marginally significant $(p=0.075)$ increase (table 2$)$. This level of significance provides some evidence that the increasing trend was caused by processes supplying or transporting ammonia in the river rather than by the particular sequence of streamflows on dates when samples were collected. Unusual sequences of streamflows could have been the cause of the apparent trends or lack of trends at monitoring sites that lack streamflow data.

Concentrations of nitrate have increased at sites WR248, WR210, and EW79 but have decreased at site MU20 (figs. 17 and 20, table 3). Increased concentrations of nitrate at site WR210 were caused by improvements to the Indianapolis sewage-treatment plants. Median concentrations of nitrate in the White River downstream from Indianapolis increased from $2.5 \mathrm{mg} / \mathrm{L}$ before 
improvements were made to $4.9 \mathrm{mg} / \mathrm{L}$ after improvements were made (Crawford and Wangsness, 1991a, p. 21). Concentrations of nitrate increased because, after 1983, nitrification of ammonia occurred in the treatment plants instead of in the river. The decreasing trend in nitrate at MU20 is a consequence of a period of high concentrations in the early 1980's (fig. 17). The cause of the high nitrate concentrations probably was related to point-source discharges.

The increasing trends in nitrate concentrations at sites WR248 and EW79 may have been related to the particular sequence of streamflows on dates when samples were collected rather than to processes controlling nitrate in the rivers because streamflow-adjusted concentrations of nitrate did not exhibit statistically significant trends (table 3 ). Streamflow-adjusted concentrations of nitrate decreased at site WR319; the significance level of this test indicates that the processes controlling nitrate at this site have changed but the decreasing trend in concentrations has been masked by the particular sequence of streamflows on the days when samples were collected.

A basin-wide increase in nitrate concentrations was apparent during winter 1988 to spring 1989 (fig. 17). These high nitrate concentrations probably were caused by the leaching and transport of nitrate that accumulated in the soil during the drought of 1988 (Fowler, 1992).

The seasonal Kendall test was not done for total nitrogen because of the short and variable period of record for this constituent. Time-series plots of total nitrogen generally follow the same patterns as nitrate (for example, sites WR348, WR46, and EW79; figs. 17 and 18). Differences are apparent at site WR210 during 1980-83 and at site EC21, where much of the total nitrogen was ammonia.

Concentrations of total phosphorus have increased at sites WR309, WR293, WR279, WR248, WR46, EW1, and MU20 but have decreased at sites EC21 and EC1 (figs. 19 and 20, table 4). Increased concentrations in the upstream reach of the White River probably were not associated with agricultural nonpoint sources of phosphorus because sites WR348, WR319, MC35, and $\mathrm{MC} 18$ (which are predominantly affected by agriculture) did not exhibit similar trends. In addition, trends in the annual sales of phosphate fertilizers statewide indicate decreasing sales during 1980-90 (Mann-Kendall tau-b correlation coefficient $=-0.6, p=0.010$ ). Increasing trends in total phosphorus in the upstream reach of the White River may have been associated with changes in point-source discharges. Rapid population growth during 1980-90 in Hamilton County probably resulted in increased loads of phosphorus discharged by the Carmel sewagetreatment plant. Increased population probably was not the cause of the increasing trends in the White River downstream from Muncie and Anderson because the counties that contain these cities lost population during 1980-90.

The increasing trends in concentrations of total phosphorus downstream from Anderson could be related to decreasing rates of discharge from the Anderson sewage-treatment plant. During the 1980 's, the dry-weather discharge rate of the Anderson plant decreased from approximately $20 \mathrm{Mgal} / \mathrm{d}$ to approximately $16 \mathrm{Mgal} / \mathrm{d}$, primarily because of decreased contributions of industrial process water (Marlon Fisher, Pretreatment Division, Anderson sewage-treatment plant, oral commun., May 1995). Industrial process water probably contained low concentrations of nitrogen and phosphorus and diluted the nitrogen and phosphorus in the domestic sewage. Reduction in dilution provided by the process water may have caused increased concentrations (but not loads) of nutrients in the sewage effluent and could have contributed to increased concentrations of phosphorus in the river, especially during low streamflows. Increased concentrations of phosphorus also could have been caused by increased use of phosphate-containing anti-corrosive agents used in large water-cooling systems (John Craddock, Muncie Sanitary District, oral commun., June 1994) or by increased used of phosphatecontaining dishwasher detergents. The decreasing trends in total phosphorus at sites EC21 and EC1 may have been related to improvements in the treatment processes of the sewage-treatment plants 

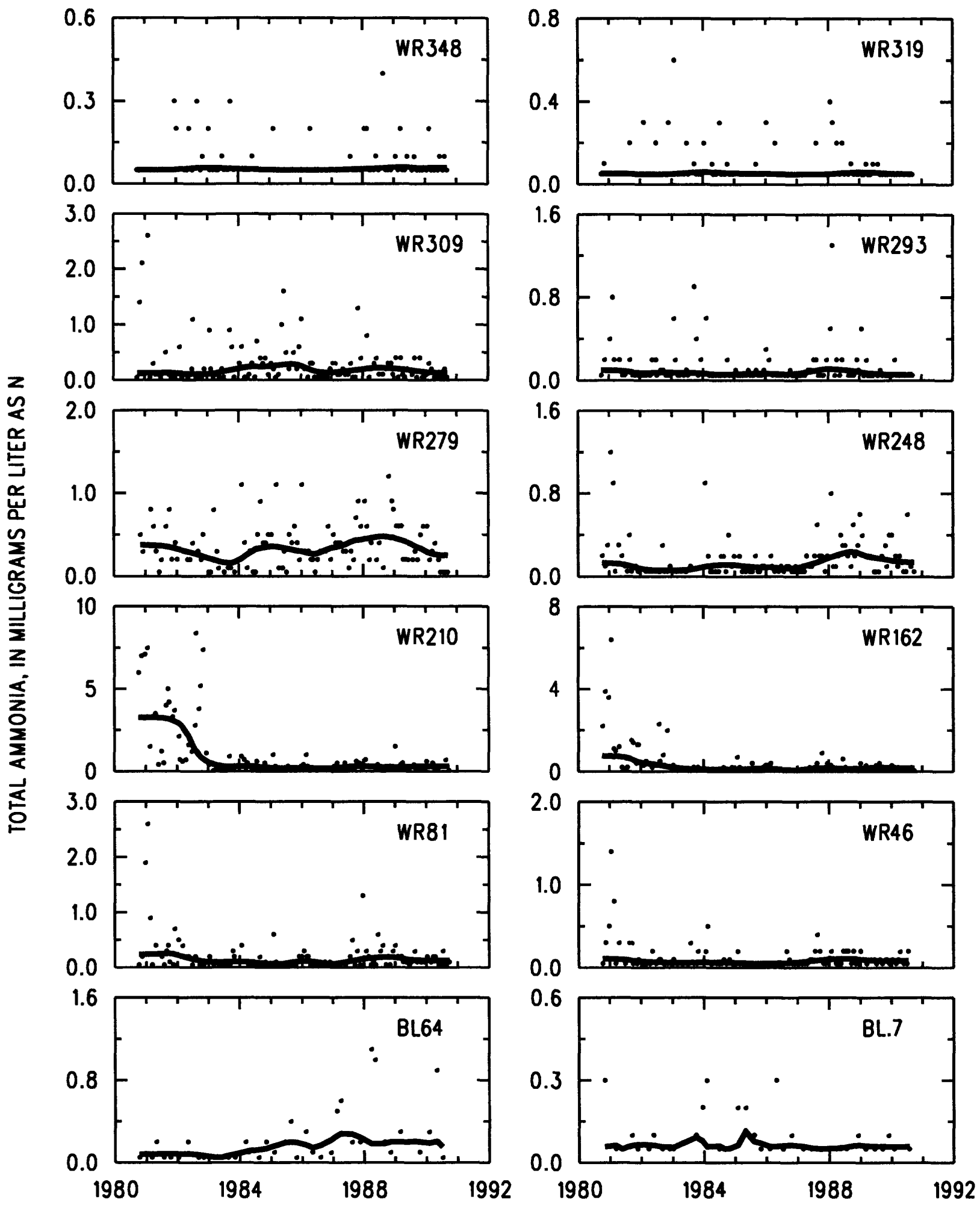

Figure 16. Concentrations of total ammonia at surface-water-quality monitoring sites in the White River Basin. Indiana, 1981-90 water years. (The line in the scatterplot is a smooth that shows the general relation between concentration and time.) 


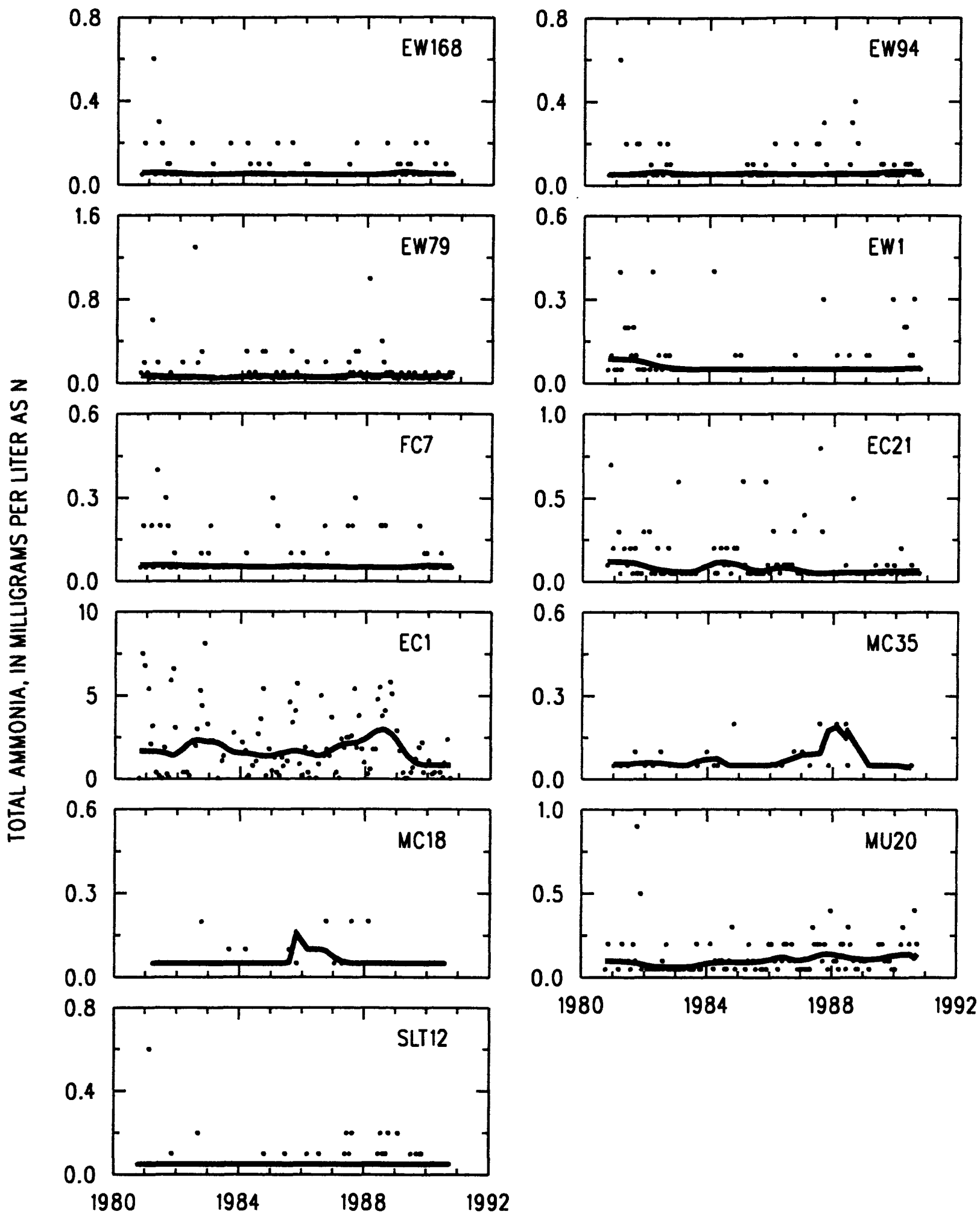

Figure 16. Concentrations of total ammonia at surface-water-quality monitoring sites in the White River Basin, Indiana, 1981-90 water years. --Continued. 

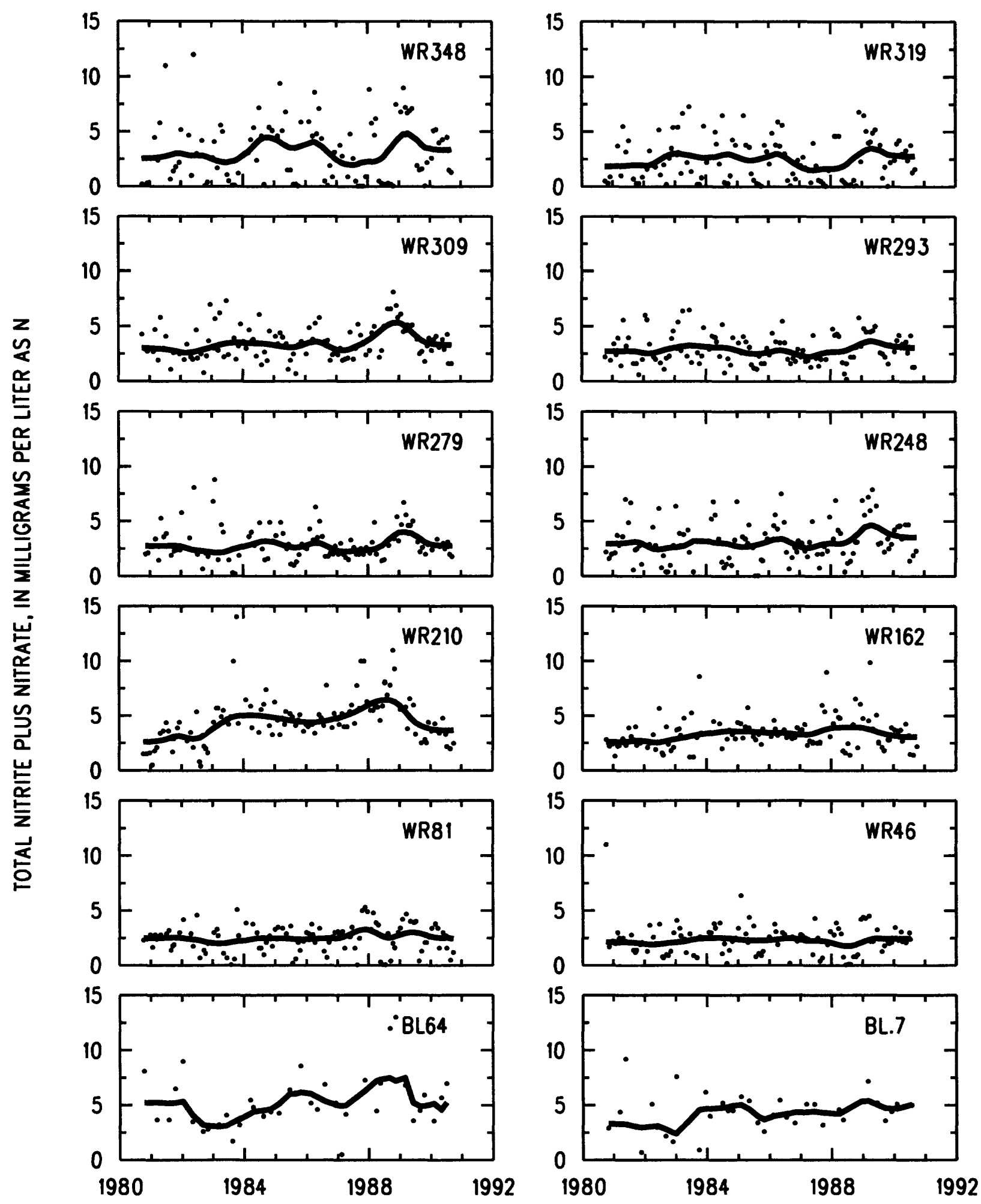

Figure 17. Concentrations of total nitrite plus nitrate at surface-water-quality monitoring sites in the White River Basin, Indiana, 1981-90 water years. (The line in the scatterplot is a smooth that shows the general relation between concentration and time.) 


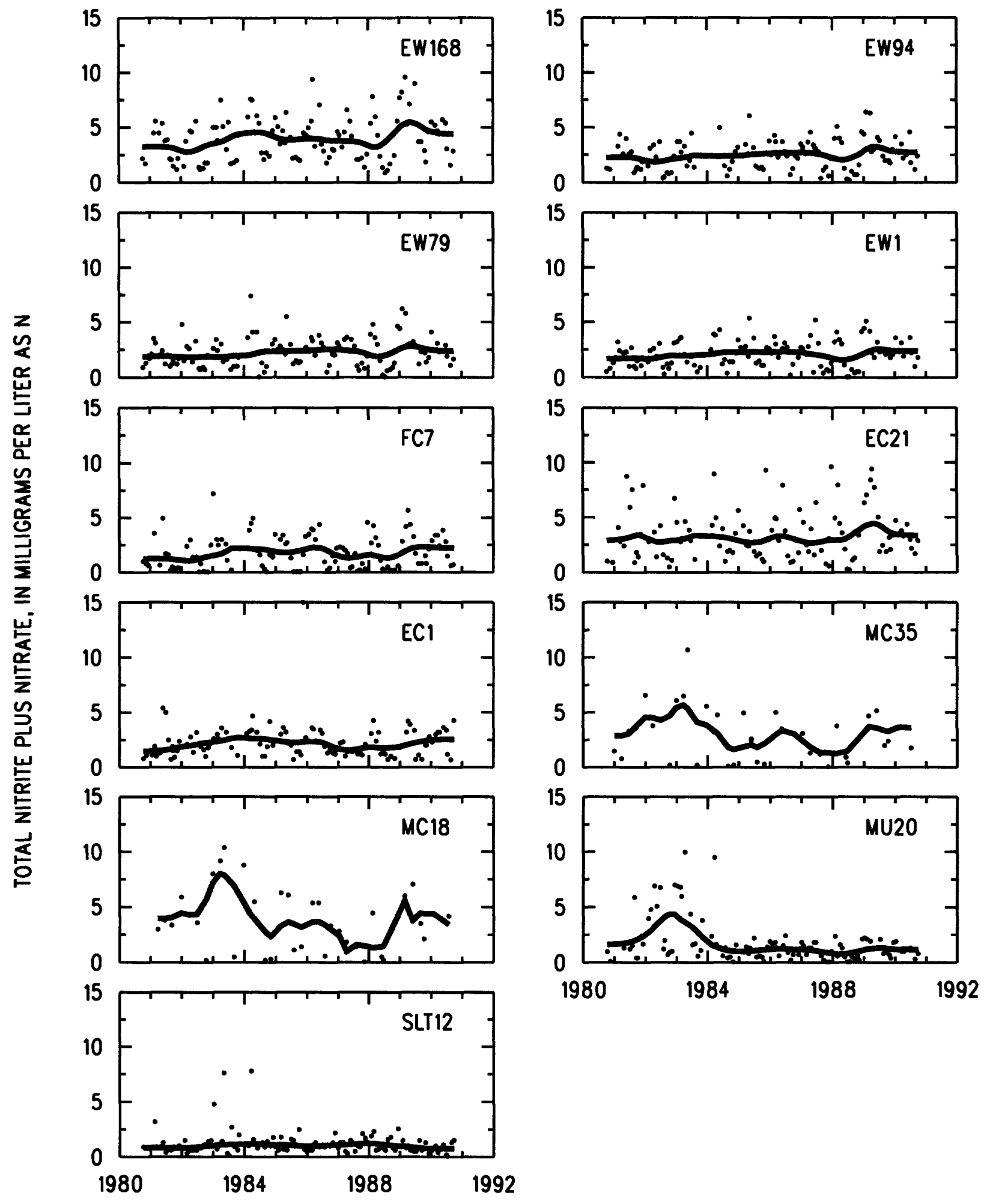

Figure 17. Concentrations of total nitrite plus nitrate at surface-water-quality monitoring sites in the White River Basin, Indiana, 1981-90 water years.--Continued. 

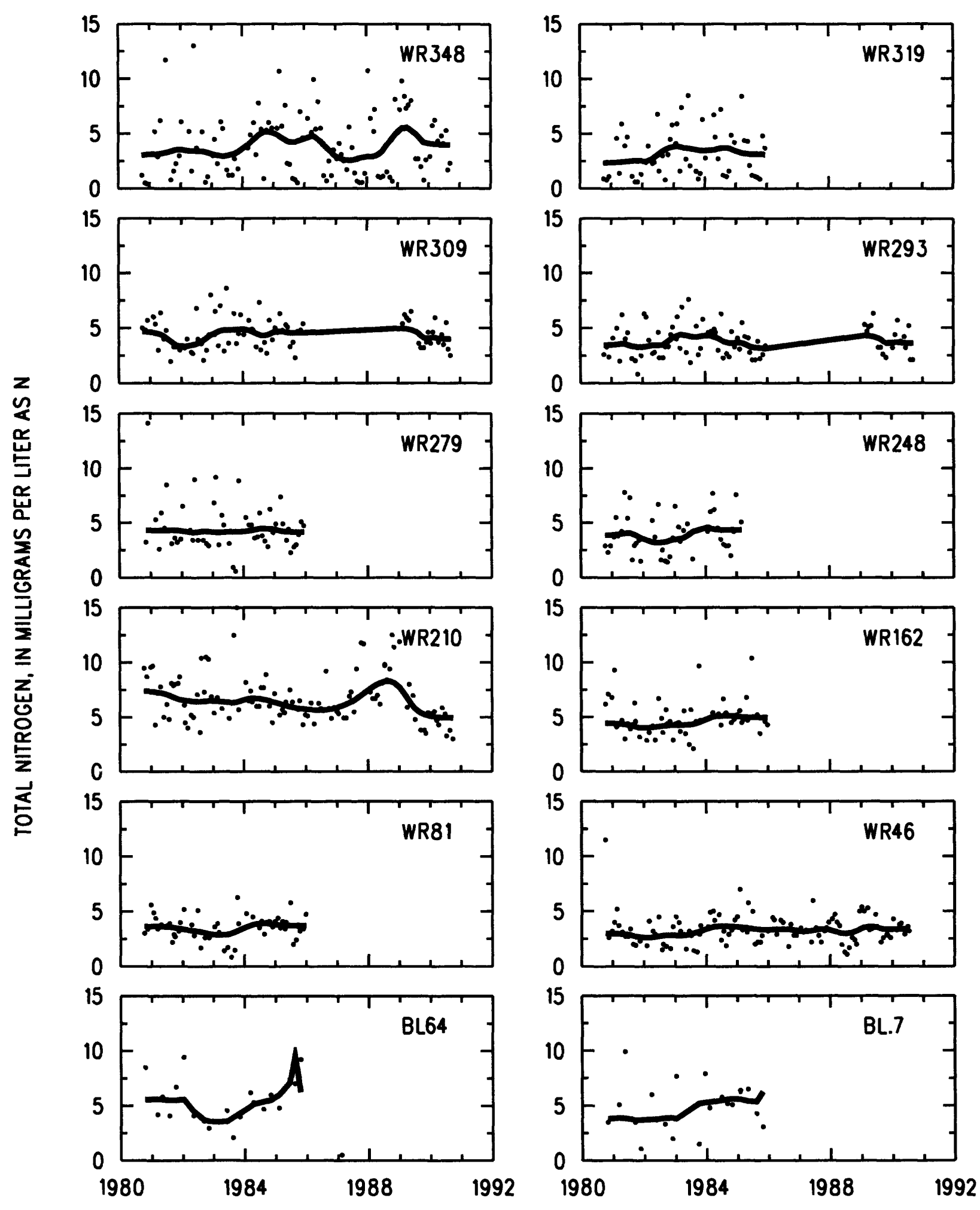

Figure 18. Concentrations of total nitrogen at surface-water-quality monitoring sites in the White River Basin, Indiana, 1981-90 water years. (The line in the scatterplot is a smooth that shows the general relation between concentration and time.) 


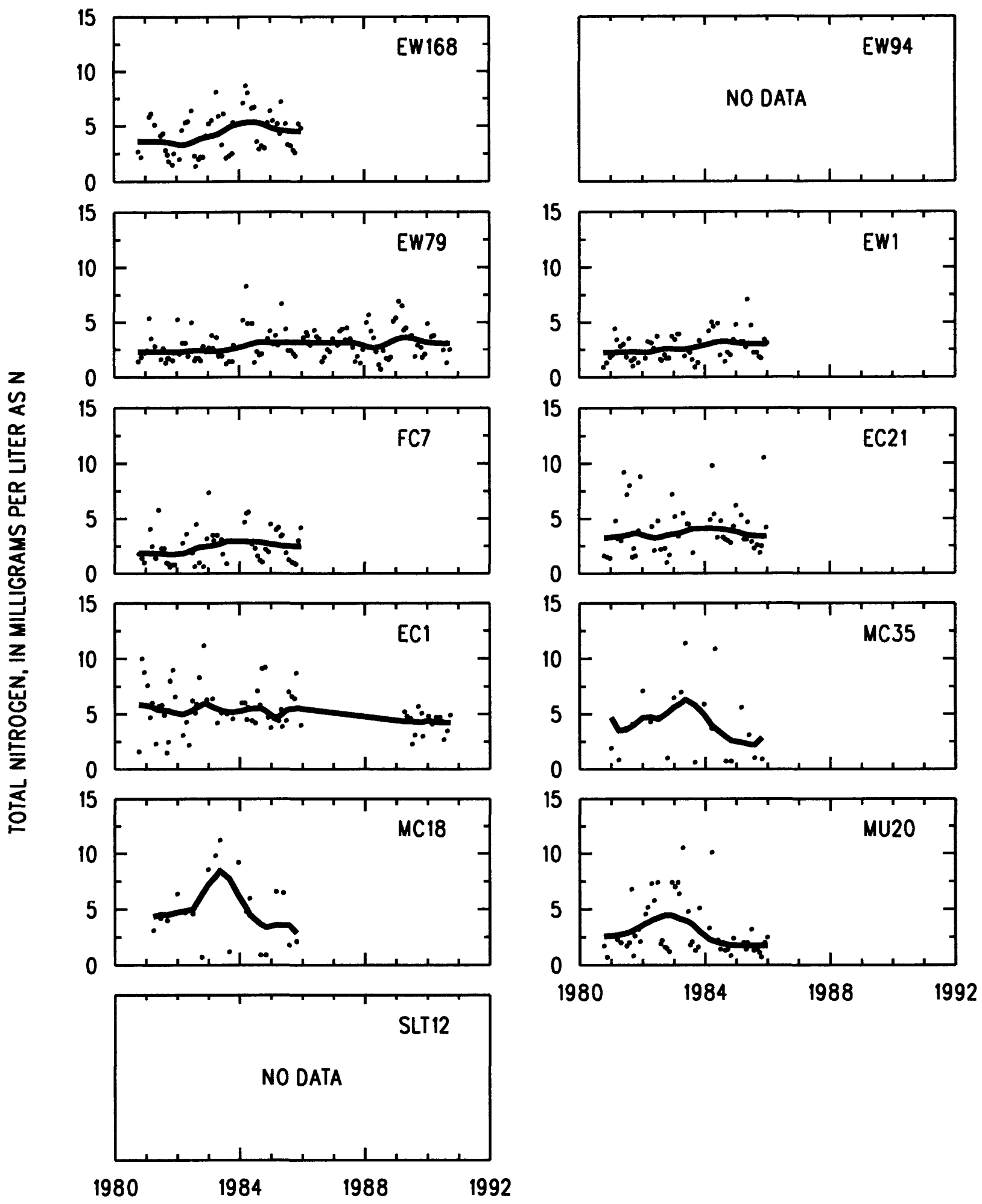

Figure 18. Concentrations of total nitrogen at surface-water-quality monitoring sites in the White River Basin. Indiana, 1981-90 water years.--Continued. 

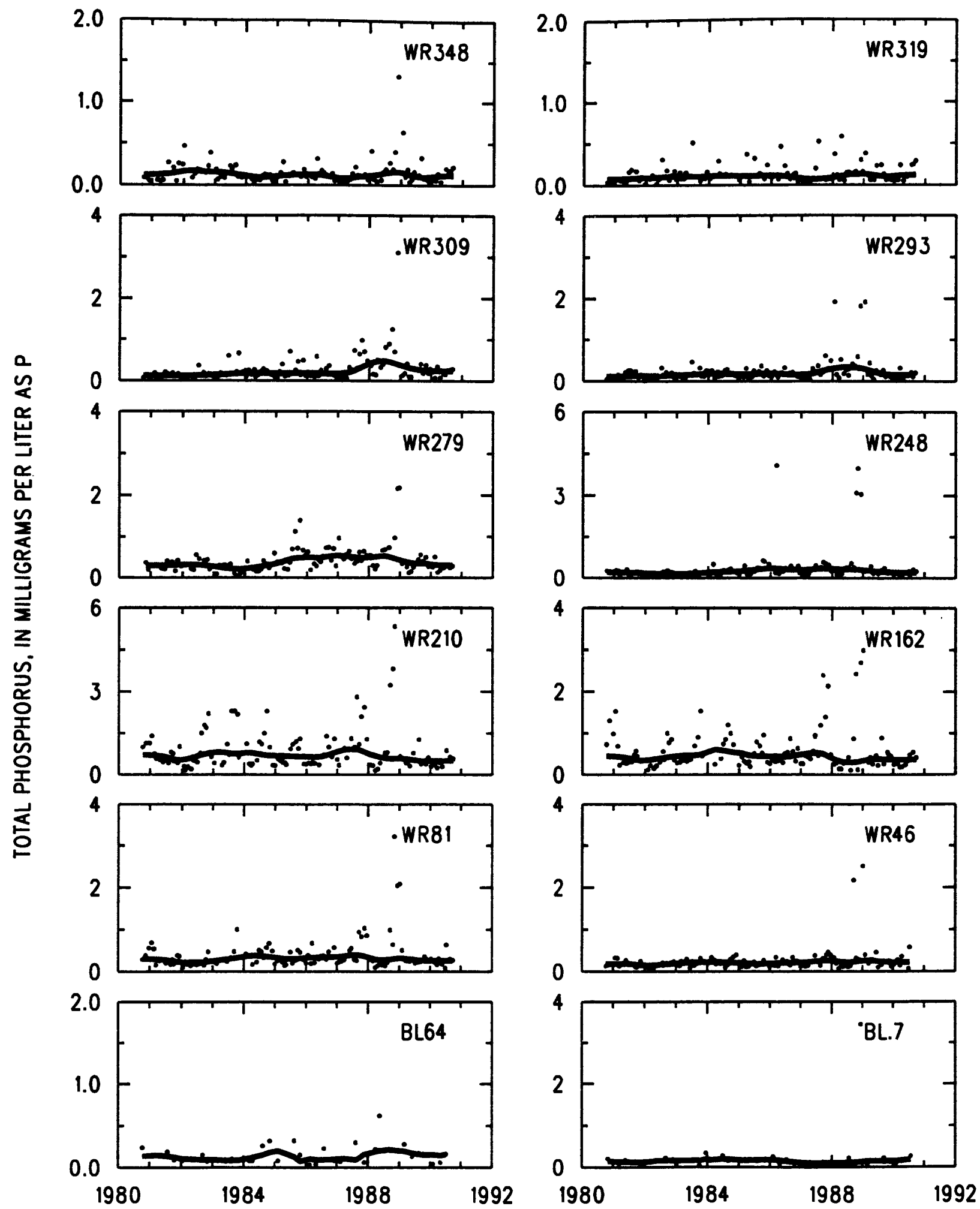

Figure 19. Concentrations of total phosphorus at surface-water-quality monitoring sites in the White River Basin, Indiana, 1981-90 water years. (The line in the scatterplot is a smooth that shows the general relation between concentration and time.) 


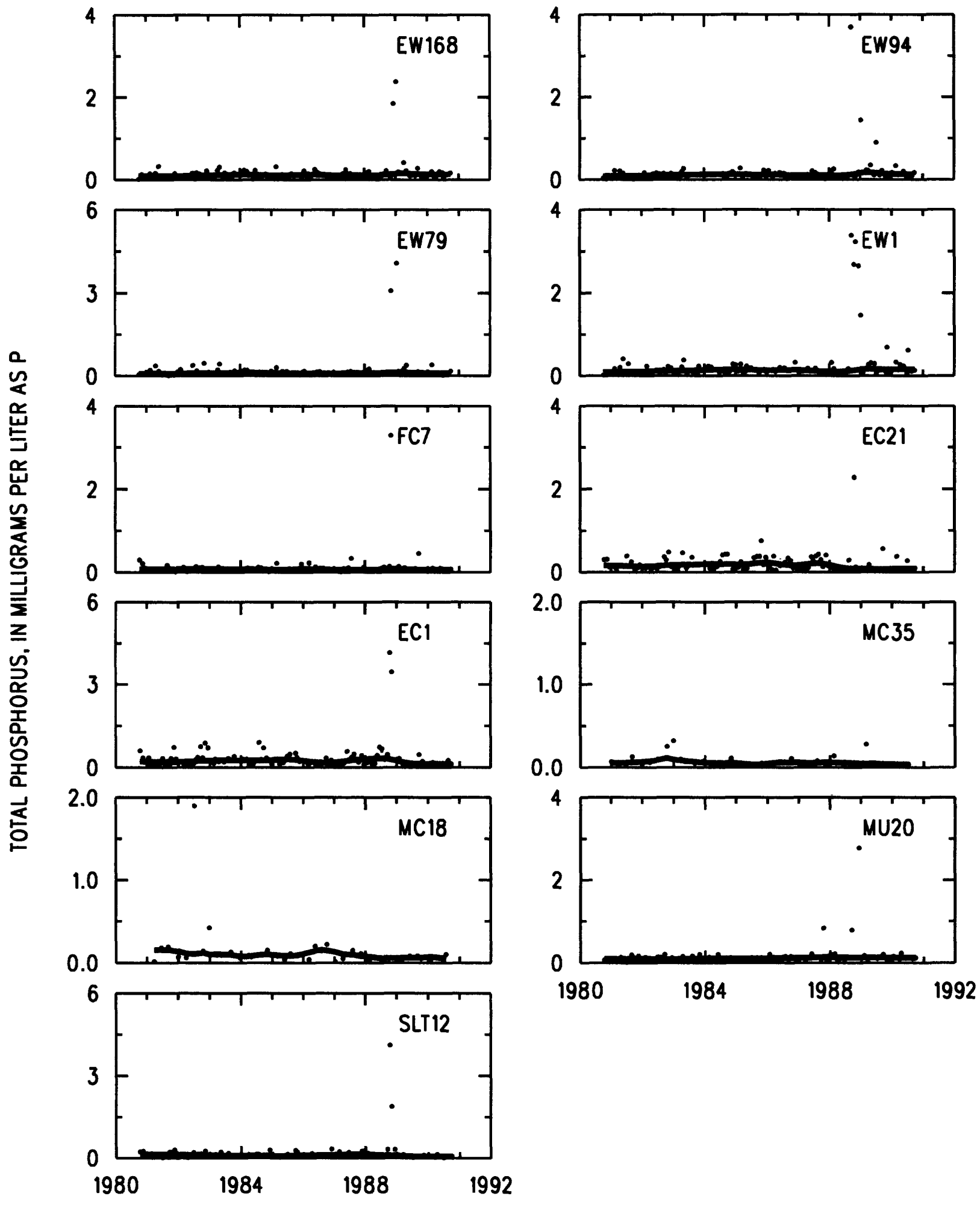

Figure 19. Concentrations of total phosphorus at surface-water-quality monitoring sites in the White River Basin, Indiana, 1981-90 water years.--Continued. 


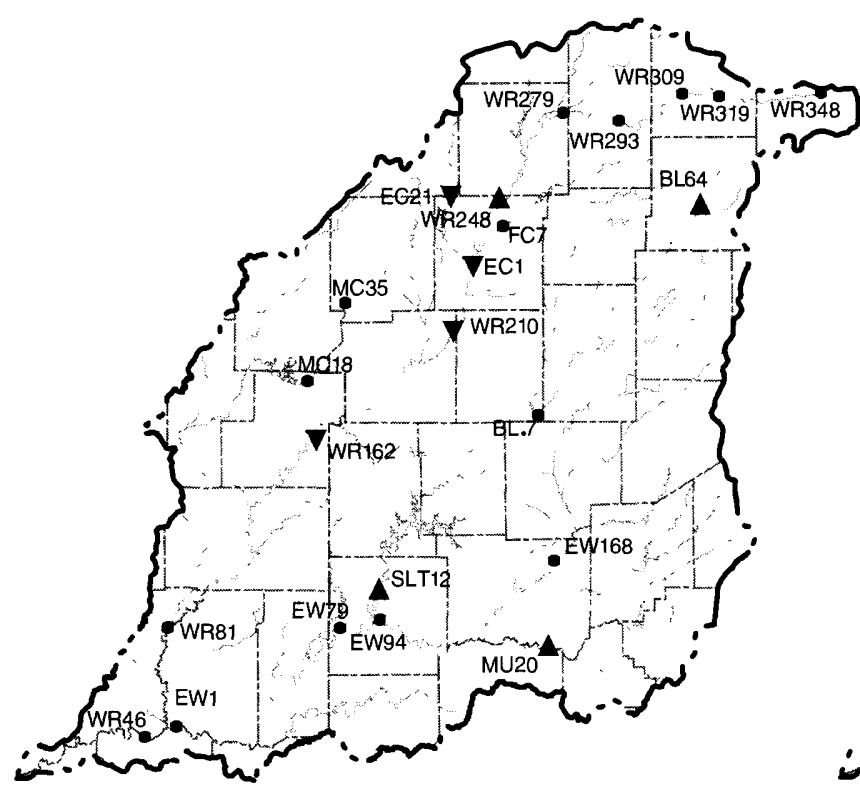

Total ammonia

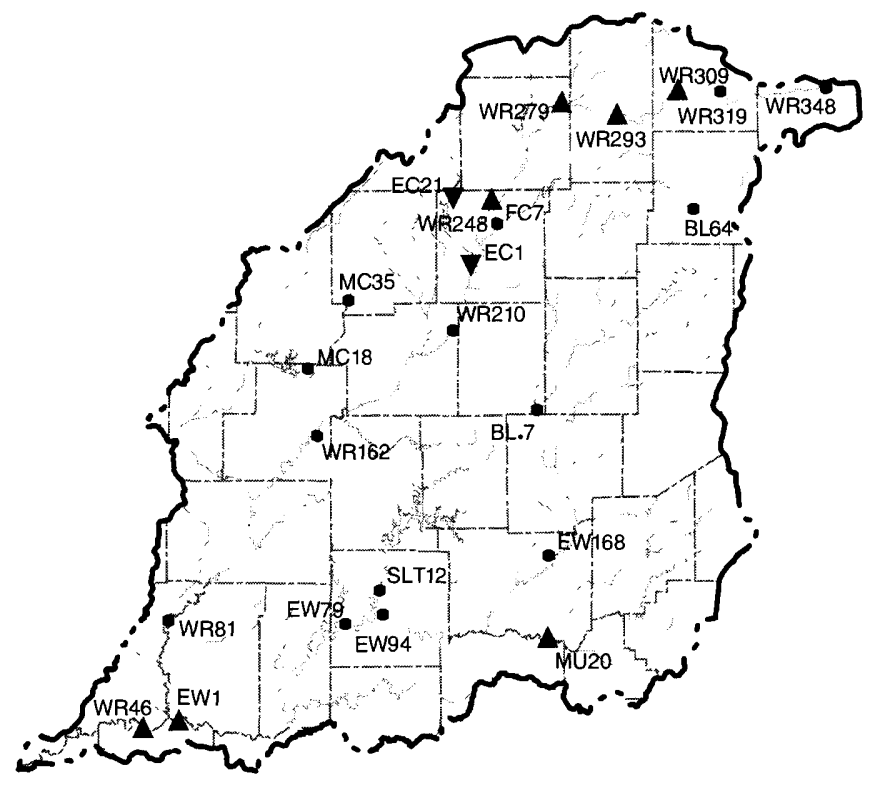

Total phosphorus

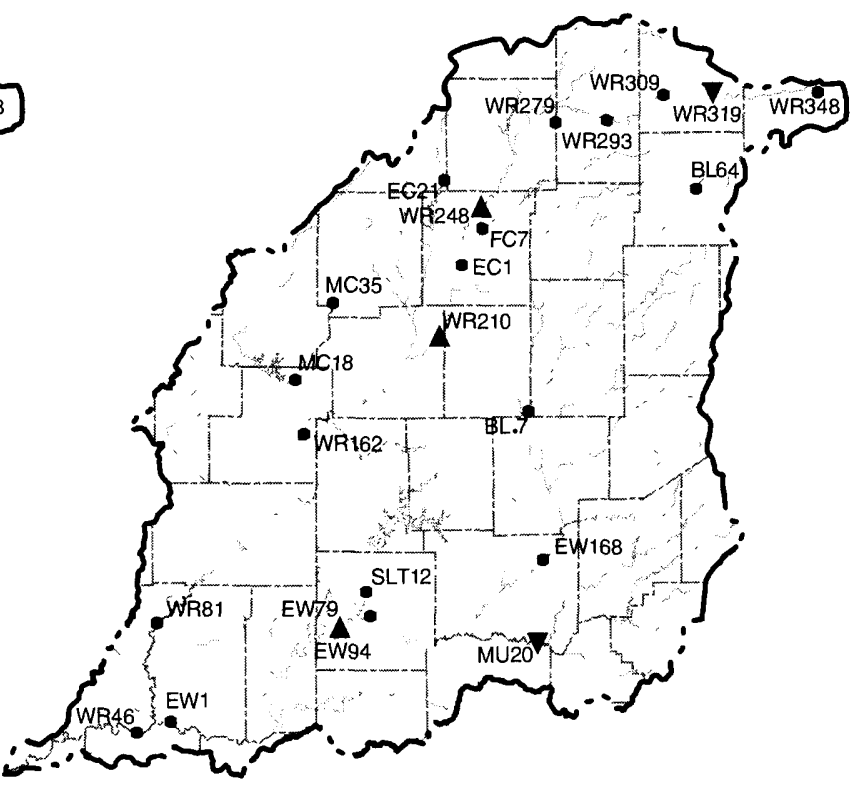

Total nitrite plus nitrate

\section{EXPLANATION}

MONITORING SITES

$\begin{array}{ll}\text { WR248 } & \text { Increasing trend at site } \\ \text { EC21 } & \text { Decreasing trend at site } \\ \text { MC35 } & \text { No trend at site } \\ & \text { White River Basin boundary } \\ & \text { County boundary }\end{array}$

Figure 20. Time trends in nutrient concentrations at selected surface-water-quality monitoring sites in the White River Basin, Indiana, 1981-90 water years. (Trends were identified if any of the tests indicated a statistically significant trend.) 
Table 2. Summary of exploratory trend analysis of concentrations of total ammonia at surface-water-quality monitoring sites in the White River Basin, Indiana, 1981-90 water years

[tau-b, the Kendall correlation coefficient; $\mathrm{p}$, the probability of obtaining the trend test result by chance when in fact there is no trend (results in bold are significant at $\mathrm{p} \leq 0.05$ ); $\mathrm{mg} / \mathrm{L}$ as $\mathrm{N}$, milligrams per liter as nitrogen; --, no streamflow data to perform test; + , increasing trend; -, decreasing trend; <, less than]

\begin{tabular}{|c|c|c|c|c|c|c|c|}
\hline \multirow[b]{2}{*}{$\begin{array}{c}\text { Site } \\
\text { number }\end{array}$} & \multirow{2}{*}{$\begin{array}{l}\text { Median total } \\
\text { ammonia } \\
\text { concentration } \\
(\mathrm{mg} / \mathrm{L} \text { as } \mathrm{N})\end{array}$} & \multicolumn{2}{|c|}{ Mann-Kendall test } & \multicolumn{2}{|c|}{ Seasonal Kendall test } & \multicolumn{2}{|c|}{$\begin{array}{l}\text { Seasonal Kendall test on } \\
\text { streamflow-adjusted } \\
\text { concentrations }\end{array}$} \\
\hline & & tau-b & p & $\begin{array}{l}\text { Trend } \\
\text { slope }^{1}\end{array}$ & $p$ & $\begin{array}{l}\text { Trend } \\
\text { slope }^{1}\end{array}$ & p \\
\hline \multicolumn{8}{|c|}{ Sites on White River } \\
\hline WR348 & $<0.1$ & 0.04 & 0.61 & - & 0.32 & -- & -- \\
\hline WR319 & $<.1$ & -.07 & .39 & - & .095 & - & 0.20 \\
\hline WR309 & .2 & -.05 & .47 & - & .23 & -- & -- \\
\hline WR293 & $<.1$ & -.10 & .15 & - & .24 & - & 2.96 \\
\hline WR279 & .3 & .01 & .83 & - & .95 & -- & -- \\
\hline WR248 & .1 & .18 & .011 & + & .13 & + & ${ }^{2} .075$ \\
\hline WR210 & .3 & -.28 & .0001 & - & .0001 & - & .0007 \\
\hline WR 162 & .2 & -.25 & .0002 & - & .0001 & -- & -- \\
\hline WR81 & .1 & -.02 & .79 & - & .059 & - & .81 \\
\hline WR46 & $<.1$ & .00 & .97 & - & .33 & - & .77 \\
\hline \multicolumn{8}{|c|}{ Sites on East Fork White River } \\
\hline BL64 & .5 & .43 & .0003 & + & .027 & -- & - \\
\hline BL. 7 & $<.1$ & -.16 & .23 & - & .25 & -- & -- \\
\hline EW168 & $<.1$ & -.06 & .42 & - & .10 & + & .88 \\
\hline EW94 & $<.1$ & .01 & .94 & - & .32 & + & .65 \\
\hline EW79 & $<.1$ & .00 & .94 & - & .066 & - & .90 \\
\hline EW1 & $<.1$ & -.06 & .43 & - & .65 & -- & -- \\
\hline \multicolumn{8}{|c|}{ Sites on Tributaries } \\
\hline FC7 & $<.1$ & -.10 & .20 & - & .21 & + & .57 \\
\hline EC21 & $<.1$ & -.20 & .0072 & - & .0006 & - & -- \\
\hline $\mathrm{ECl}$ & 1.8 & -.09 & .15 & - & .036 & -- & -- \\
\hline MC35 & $<.1$ & .04 & .77 & - & .80 & -- & -- \\
\hline MC18 & $<.1$ & .05 & .68 & - & .77 & + & .99 \\
\hline MU20 & .1 & .21 & .0050 & + & .081 & -- & -- \\
\hline SLT12 & $<.1$ & .16 & .034 & + & .68 & -- & -- \\
\hline
\end{tabular}

${ }^{1}$ Estimates of the trend slope in percent per year could not be calculated because of the large amounts of censored data.

${ }^{2}$ Streamflow-adjusted trends at these monitoring sites may be invalid because of possible changes in the probability distribution of base flow caused by changes in the discharge rates of sewage-treatment plants located upstream. 
Table 3. Summary of exploratory trend analysis of concentrations of total nitrite plus nitrate at surface-water-quality monitoring sites in the White River Basin, Indiana, 1981-90 water years

[tau-b, the Kendall correlation coefficient; $p$, the probability of obtaining the trend test result by chance when in fact there is no trend (results in bold are significant at $\mathrm{p} \leq 0.05$ ); pct/yr, percent per year; $\mathrm{mg} / \mathrm{L}$ as $\mathrm{N}$, milligrams per liter as nitrogen; --, no streamflow data to perform test]

\begin{tabular}{|c|c|c|c|c|c|c|c|}
\hline \multirow[b]{2}{*}{$\begin{array}{c}\text { Site } \\
\text { number }\end{array}$} & \multirow{2}{*}{$\begin{array}{l}\text { Median total } \\
\text { nitrite plus } \\
\text { nitrate } \\
\text { concentration } \\
\text { (mg/L as N) }\end{array}$} & \multicolumn{2}{|c|}{ Mann-Kendall test } & \multicolumn{2}{|c|}{ Seasonal Kendall test } & \multicolumn{2}{|c|}{$\begin{array}{l}\text { Seasonal Kendall test on } \\
\text { streamflow-adjusted } \\
\text { concentrations }\end{array}$} \\
\hline & & tau-b & p & $\begin{array}{l}\text { Trend } \\
\text { slope } \\
\text { (pct/yr) }\end{array}$ & $\mathbf{p}$ & $\begin{array}{l}\text { Trend } \\
\text { slope } \\
\text { (pct/yr) }\end{array}$ & $\mathbf{p}$ \\
\hline \multicolumn{8}{|c|}{ Sites on White River } \\
\hline WR348 & 2.7 & 0.03 & 0.67 & 1.6 & 0.41 & -- & -- \\
\hline WR319 & 2.2 & .03 & .68 & .3 & .75 & -4.3 & 0.015 \\
\hline WR309 & 3.4 & .10 & .097 & 2.2 & .22 & -- & -- \\
\hline WR293 & 2.6 & .02 & .69 & 1.3 & .23 & -2.0 & ${ }^{1} .15$ \\
\hline WR279 & 2.6 & .03 & .67 & 1.8 & .34 & -- & -- \\
\hline WR248 & 2.9 & .11 & .10 & 5.4 & .0004 & 1.9 & ${ }^{1} .21$ \\
\hline WR210 & 4.4 & .23 & .0002 & 4.5 & .0030 & 3.5 & .031 \\
\hline WR162 & 3.2 & .12 & .054 & 2.1 & .23 & -- & -- \\
\hline WR81 & 2.6 & .06 & .39 & 1.6 & .37 & .3 & .97 \\
\hline WR46 & 2.4 & .02 & .78 & .0 & .79 & -.9 & .47 \\
\hline \multicolumn{8}{|c|}{ Sites on East Fork White River } \\
\hline BL64 & 4.8 & .20 & .068 & 7.1 & .058 & -- & - \\
\hline BL. 7 & 4.4 & .15 & .21 & 1.2 & .25 & -- & -- \\
\hline EW168 & 3.8 & .11 & .091 & 1.9 & .071 & .4 & .43 \\
\hline EW94 & 2.4 & .09 & .17 & 2.9 & .12 & 1.3 & .22 \\
\hline EW79 & 2.1 & .09 & .14 & 2.7 & .034 & 1.5 & .32 \\
\hline EW1 & 2.1 & .10 & .12 & 2.9 & .075 & -- & -- \\
\hline \multicolumn{8}{|c|}{ Sites on Tributaries } \\
\hline FC7 & 1.6 & .07 & .29 & 3.8 & .074 & -.8 & .63 \\
\hline $\mathrm{EC} 21$ & 2.9 & .06 & .37 & 3.4 & .058 & -- & -- \\
\hline $\mathrm{ECl}$ & 2.0 & .02 & .73 & .9 & .45 & -- & - \\
\hline MC35 & 3.1 & -.11 & .33 & 14 & .54 & -- & -- \\
\hline $\mathrm{MC} 18$ & 3.6 & -.11 & .36 & 9.5 & .62 & -4.0 & .45 \\
\hline MU20 & 1.3 & -.20 & .0030 & -11 & .0008 & -- & -- \\
\hline SLT12 & .9 & -.04 & .52 & .0 & .93 & -- & -- \\
\hline
\end{tabular}

${ }^{1}$ Streamflow-adjusted trends at these monitoring sites may be invalid because of possible changes in the probability distribution of base flow caused by changes in the discharge rates of sewage-treatment plants located upstream. 
Table 4. Summary of exploratory trend analysis of concentrations of total phosphorus at surface-water-quality monitoring sites in the White River Basin, Indiana, 1981-90 water years

[tau-b, the Kendall correlation coefficient; $p$, the probability of obtaining the trend test result by chance when in fact there is no trend (results in bold are significant at $\mathrm{p} \leq 0.05$ ); $\mathrm{pct} / \mathrm{yr}$, percent per year; $\mathrm{mg} / \mathrm{L}$ as $\mathrm{P}$, milligrams per liter as phosphorus; --, no streamflow data to perform test]

\begin{tabular}{|c|c|c|c|c|c|c|c|}
\hline \multirow[b]{2}{*}{$\begin{array}{c}\text { Site } \\
\text { number }\end{array}$} & \multirow{2}{*}{$\begin{array}{l}\text { Median total } \\
\text { phosphorus } \\
\text { concentration } \\
(\mathrm{mg} / \mathrm{L} \text { as P) }\end{array}$} & \multicolumn{2}{|c|}{ Mann-Kendall test } & \multicolumn{2}{|c|}{ Seasonal Kendall test } & \multicolumn{2}{|c|}{$\begin{array}{l}\text { Seasonal Kendall test on } \\
\text { streamflow-adjusted } \\
\text { concentrations }\end{array}$} \\
\hline & & tau-b & $\mathbf{p}$ & $\begin{array}{l}\text { Trend } \\
\text { slope } \\
\text { (pet/yr) }\end{array}$ & $\mathbf{p}$ & $\begin{array}{l}\text { Trend } \\
\text { slope } \\
\text { (pct/yr) }\end{array}$ & $\mathbf{p}$ \\
\hline \multicolumn{8}{|c|}{ Sites on White River } \\
\hline WR348 & 0.12 & -0.00 & 0.99 & 0.0 & 0.77 & -- & -- \\
\hline WR319 & .11 & .09 & .15 & 3.7 & .077 & 0.2 & 0.93 \\
\hline WR309 & .18 & .27 & .0001 & 9.1 & .0001 & -- & -- \\
\hline WR293 & .16 & .19 & .0025 & 3.9 & .079 & 2.0 & ${ }^{1} .14$ \\
\hline WR279 & .36 & .15 & .021 & 3.0 & .21 & -- & -- \\
\hline WR248 & .24 & .18 & .0065 & 5.7 & .0013 & 6.2 & ${ }^{1} .0001$ \\
\hline WR210 & .64 & -.07 & .29 & -1.7 & .25 & 1.3 & .57 \\
\hline WR162 & .42 & -.06 & .39 & -.8 & .63 & -- & -- \\
\hline WR81 & .28 & .05 & .43 & 2.4 & .16 & 3.3 & .099 \\
\hline WR46 & .20 & .14 & .030 & 2.7 & .047 & 1.8 & .12 \\
\hline \multicolumn{8}{|c|}{ Sites on East Fork White River } \\
\hline BL64 & .12 & .00 & .98 & -2.5 & .86 & -- & -- \\
\hline BL.7 & .15 & -.02 & .83 & -1.3 & .57 & -- & -- \\
\hline EW168 & .11 & .11 & .091 & 1.6 & .42 & 2.1 & .25 \\
\hline EW94 & .10 & .13 & .059 & 2.5 & .17 & 2.3 & .16 \\
\hline EW79 & .10 & .07 & .26 & .0 & .54 & 1.4 & .25 \\
\hline EW1 & .13 & .18 & .0042 & 6.3 & .0059 & -- & -- \\
\hline \multicolumn{8}{|c|}{ Sites on Tributaries } \\
\hline FC7 & .08 & -.09 & .19 & -2.8 & .11 & -1.0 & .47 \\
\hline EC21 & .13 & -.17 & .0089 & -5.6 & .031 & -- & -- \\
\hline $\mathrm{ECl}$ & .23 & -.14 & .028 & -6.5 & .0019 & -- & -- \\
\hline MC35 & .05 & -.17 & .16 & .0 & .99 & -- & -- \\
\hline MC18 & .08 & -.21 & .070 & -7.4 & .38 & -1.5 & .99 \\
\hline MU20 & .11 & .23 & .0009 & 4.1 & .017 & -- & -- \\
\hline SLT12 & .10 & -.08 & .20 & -.4 & .39 & -- & -- \\
\hline
\end{tabular}

${ }^{1}$ Streamflow-adjusted trends at these monitoring sites may be invalid because of possible changes in the probability distribution of base flow caused by changes in the discharge rates of sewage-treatment plants located upstream. 
upstream from these monitoring sites. Confirmation of the apparent trends and their cause(s) would require a more detailed analysis, including analysis of trends in point-source concentrations, flows, and loads.

Increasing trends in total phosphorus at sites WR293 and WR46 may have been caused by unusual sequences of streamflows because increasing trends in streamflow-adjusted concentrations were only marginally significant (table 4). The increasing trend in streamflow-adjusted concentrations of total phosphorus at site WR248 is highly significant, which indicates that the processes contributing or transporting total phosphorus in the river, rather than a particular sequence of streamflows, are responsible for the trend. Unusual sequences of streamflows may have been the cause of the apparent trends or lack of trends at the other monitoring sites that lack streamflow data.

Basin-wide increasing trends in organic nitrogen and decreasing trends in specific conductance were indicated by results of the Mann-Kendall test. Increasing trends in organic nitrogen were indicated at 17 of the 22 monitoring sites with data. Decreasing trends in specific conductance were indicated at 17 of the 21 sites with data. Time-series plots of these data show gradual increases or decreases rather than an obvious step change that might be associated with a change in sample collection or analysis protocols. The causes of the basin-wide trends are not known and, because of the basin-wide occurrence, probably are not caused by unusual sequences of streamflows on dates when samples were collected.

\section{Mass Transport of Nutrients in Rivers}

Nutrient input-output budgets are useful tools for the analysis of drainage-basin processes and nutrient cycling (Likens and others, 1977; Hickman, 1984; LaBaugh and Winter, 1984; Hager and Schemel, 1992; Jaworski and others, 1992). Analysis of nutrient inputs and outputs provides information on the sources and fates of nutrients. Estimation of the mass of nutrients discharged by streams (termed fluxes or loads) is helpful in assessing the potential for eutrophication in downstream receiving waters. An understanding of the relative importance of the various sources of nutrients can facilitate development of effective nutrient-control strategies. This section of the assessment provides estimates of nutrient inputs from some of the major sources and estimates of nutrient transport in rivers in the White River Basin.

\section{Point and Nonpoint Sources of Nutrients}

Commercial fertilizer applied to agricultural and urban land was the major input of nitrogen to the White River Basin. Of the estimated total nitrogen input to selected large drainage basins, commercial fertilizer composed 61 to 71 percent; manure from farm animals composed 14 to 20 percent; atmospheric deposition composed 11 to 19 percent; municipal sewage composed 0.1 to 9 percent; and industrial discharges composed 0.4 to 0.7 percent (calculated from data in table 5). Nitrogen inputs from the atmospheric fixation of nitrogen gas, non-farm animal wastes, septic systems, or combined-sewer overflows and urban runoff were not estimated. Methods of estimation are discussed in the section "Data Compilation, Screening, and Methods of Analysis."

Commercial fertilizer also was the major input of phosphorus to the White River Basin. Of the estimated total phosphorus input to selected large drainage basins, commercial fertilizer composed 54 to 63 percent; manure from farm animals composed 23 to 35 percent; municipal sewage composed 2 to 21 percent; and industrial discharges composed 0.4 to 1 percent (calculated from data in table 6). Phosphorus inputs from atmospheric deposition, non-farm animal wastes, septic systems, or combined-sewer overflows and urban runoff were not estimated.

Inputs of nitrogen and phosphorus from commercial fertilizers were greater in the upstream reaches of the East Fork White River (site EW168) and the White River (sites WR248, WR210) than at monitoring sites downstream (sites WR81, WR46, EW79) (tables 5 and 6). Nutrient input from farm-animal wastes was at least 44 percent 
Table 5. Estimated inputs of nitrogen to selected drainage basins and mean annual nitrogen yields at selected surface-water-quality monitoring sites in the White River Basin, Indiana, 1981-90 water years

\begin{tabular}{lccccccc}
\hline & \multicolumn{7}{c}{ Nitrogen (tons per square mile per year) } \\
\cline { 2 - 7 } \multicolumn{1}{c}{ Input or yield } & WR248 & WR210 & WR81 & WR46 & EW168 & EW79 \\
\cline { 2 - 7 } & 0.79 & 1.9 & 0.86 & 0.47 & 0.18 & 0.18 \\
Municipal sewage & .087 & .14 & .098 & .11 & .10 & .11 \\
Industrial discharge & 3.0 & 3.0 & 3.0 & 3.0 & 3.0 & 3.0 \\
Atmospheric deposition & 17 & 14 & 12 & 11 & 18 & 10 \\
Commercial fertilizer & 3.6 & 3.0 & 3.1 & 3.4 & 5.3 & 3.0 \\
Farm-animal manure & 24 & 22 & 19 & 18 & 27 & 16 \\
Total basin input ${ }^{2}$ & 5.8 & 7.4 & 5.1 & 5.1 & 6.6 & 5.0 \\
Mean annual nitrogen yield & & & & & & \\
\end{tabular}

${ }^{1}$ Does not include organic nitrogen.

${ }^{2}$ Does not include fixation of atmospheric nitrogen, non-farm animal wastes, septic systems, combined-sewer overflows, or urban runoff.

Table 6. Estimated inputs of phosphorus to selected drainage basins and mean annual phosphorus yields at selected surface-water-quality monitoring sites in the White River Basin, Indiana, 1981-90 water years [nd, not determined]

\begin{tabular}{lcccccc}
\hline & \multicolumn{7}{c}{ Phosphorus (tons per square mile per year) } \\
\cline { 2 - 7 } & \multicolumn{7}{c}{ Water-quality monitoring site } \\
\cline { 2 - 7 } Input or yield & WR248 & WR210 & WR81 & WR46 & EW168 & EW79 \\
\hline Municipal sewage & 0.50 & 1.2 & 0.54 & 0.30 & 0.11 & 0.12 \\
Industrial discharge & .026 & .041 & .028 & .034 & .038 & .042 \\
Atmospheric deposition & nd & nd & nd & nd & nd & nd \\
Commercial fertilizer & 3.7 & 3.1 & 2.8 & 2.5 & 4.1 & 2.3 \\
Farm-animal manure & 1.6 & 1.3 & 1.3 & 1.4 & 2.3 & 1.3 \\
Total basin input ${ }^{1}$ & 5.9 & 5.7 & 4.6 & 4.3 & 6.5 & 3.8 \\
Mean annual phosphorus yield & .28 & .58 & .30 & .26 & .22 & .25 \\
\hline
\end{tabular}

${ }^{1}$ Does not include atmospheric deposition, non-farm animal wastes, septic systems, combined-sewer overflows, or urban runoff. 
greater in the upstream reach of the east fork than in the upstream reach of the west fork. Inputs of nitrogen and phosphorus from municipal sewage at site WR210 were at least 10 times greater than those at sites on the east fork.

Nonpoint sources of nutrients shown in tables 5 and 6 (atmospheric deposition, commercial fertilizer, and animal manure) were applied to land. The proportion of the nonpoint sources of nutrients transported from the land to surface and ground water is not known but certainly was less than that applied. Major losses of nitrogen can occur by plant uptake, denitrification to nitrogencontaining gases, and volatilization of ammonia (National Research Council, 1978, p. 20-66). Major losses of phosphorus can occur by plant uptake and by adsorption to soils and sediments (Brady, 1974, p. 456-471). Nevertheless, commercial fertilizer, animal manure, and atmospheric deposition are potentially major sources of nutrients to surface and ground water in the White River Basin.

Point sources of nutrients shown in tables 5 and 6 (municipal sewage and industrial discharges) were discharged directly to rivers and streams. Point sources of nitrogen composed 4 to 28 percent of the nitrogen transported out of these drainage basins by streamflow (table 5). Point sources of nitrogen were insufficient to account for all the nitrogen transported by streamflow, which indicates that sources other than municipal sewage and industrial discharges contributed nitrogen to streamflow. Point sources of phosphorus composed 65 to 214 percent of the phosphorus transported out of these drainage basins by streamflow. Point sources composed 188 to 214 percent of the phosphorus transport in the west fork but only 65 to 67 percent in the east fork. Point sources of phosphorus in the west fork were more than sufficient to account for all the phosphorus transported by streamflow, which indicates that plant-uptake and sediment-adsorption processes removed substantial quantities of phosphorus from streamflow or that estimates of phosphorus contributed by point sources (primarily municipal sewage) are too high.
The nutrient load of a river is the quantity (mass discharge) of nutrients that move past a fixed point in a river in a given amount of time. Although the concentrations of most nutrients decreased in the downstream reaches of the east and west forks of the White River (fig. 12), the load of nutrients increased downstream (fig. 21). Average annual loads at site WR46 (the downstream-most site in the assessment) were 1,200 tons/yr of ammonia, 40,000 tons/yr of nitrate, 57,000 tons/yr of total nitrogen, and 2,900 tons/yr of total phosphorus. Loads of nitrate and total nitrogen were greater than loads of ammonia and total phosphorus (fig. 21). Approximately 2 percent of the total nitrogen load at WR46 was ammonia, approximately 70 percent was nitrate, and approximately 28 percent was organic nitrogen.

The mean annual load of ammonia at the downstream site on the west fork of the White River (930 tons/yr at site WR81) was approximately double that at the downstream site on the East Fork White River (460 tons/yr at site EW79) (fig. 21). A greater load of ammonia probably was caused by the greater amounts of treated municipal wastewater and combined-sewer overflows that discharge to the west fork. The ammonia load at site WR 210 was about 50 percent greater than the load at site WR81, and the sum of the ammonia loads at the downstream monitoring sites on both forks (site WR8 and EW79) was about 16 percent greater than the load estimated at the site downstream from the confluence (site WR46). A greater load upstream than downstream indicates that some ammonia was lost between sites WR210 and WR81 and between the downstream sites on the east and west forks and the confluence. Nitrification of ammonia to nitrate, uptake of ammonia by aquatic plants, and volatilization were the most likely processes of ammonia removal.

Mean annual loads of nitrate and total nitrogen at the downstream monitoring sites on both forks were similar (fig. 21) even though concentrations in the east fork typically were lower than those in the west fork (fig. 12). Similar loads 


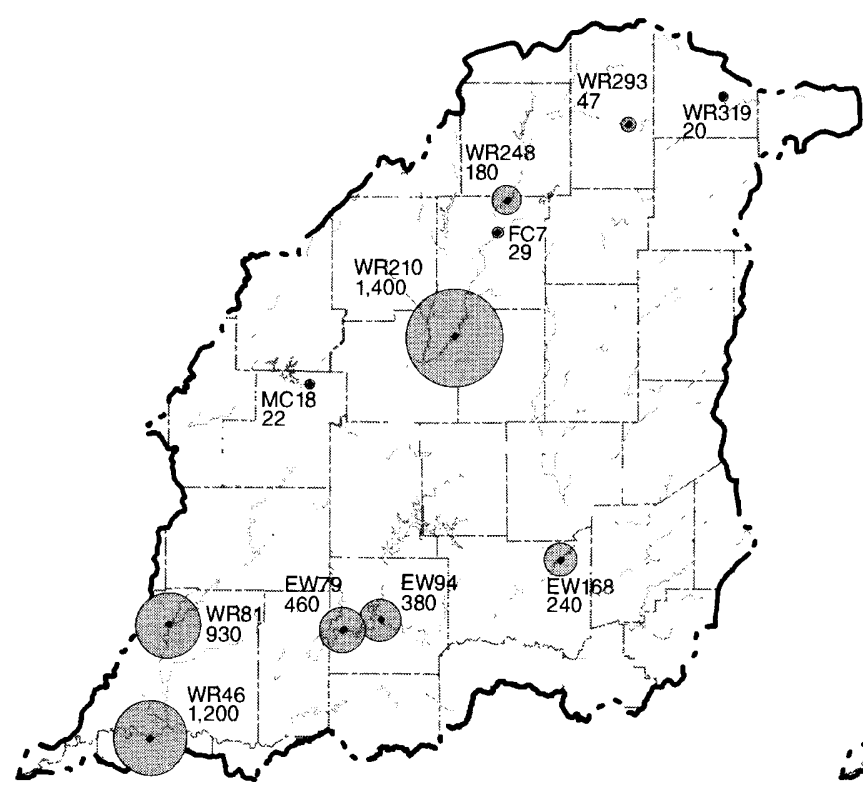

Total ammonia

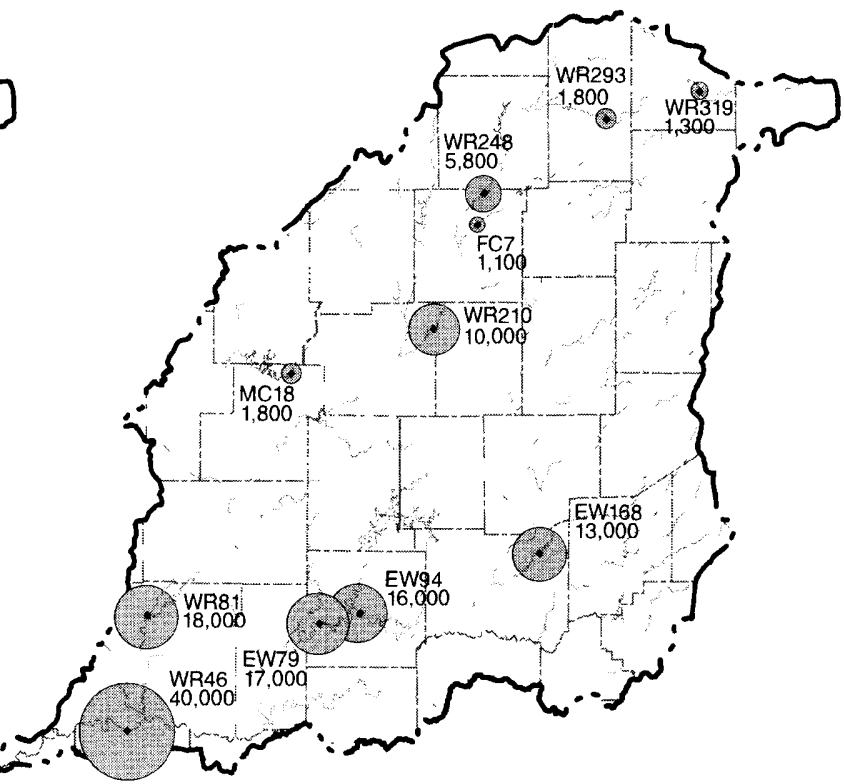

Total nitrite plus nitrate

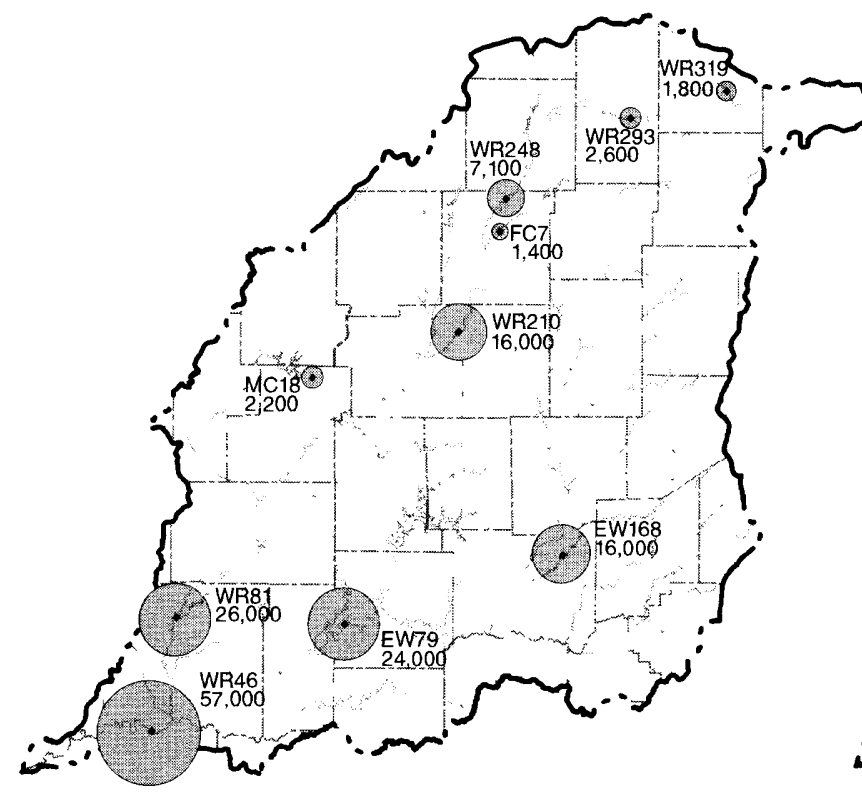

Total nitrogen

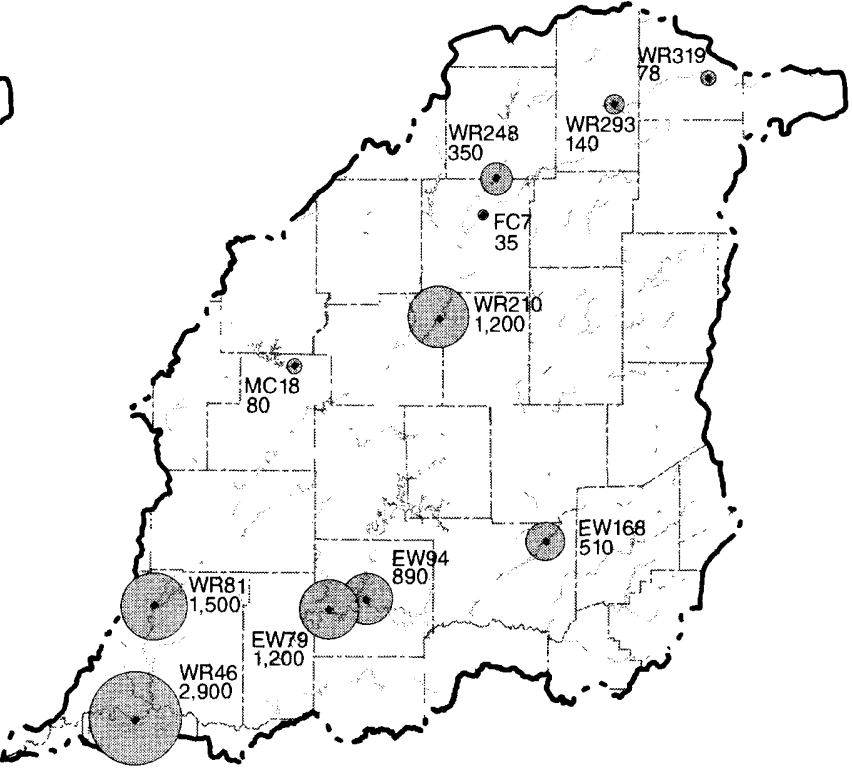

Total phosphorus

\begin{tabular}{lcccccc}
0 & 10 & 20 & 30 & 40 & MILES \\
\hline & 10 & 20 & 30 & 40 & KLLOMETERS
\end{tabular}

\section{EXPLANTION}

\section{MONITORING SITES}

Nutrient load at site, in tons per year as nitrogen or phosphorus

- White River Basin boundary

County boundary

Figure 21. Mean annual loads of nutrients at selected surface-water-quality monitoring sites in the White River Basin, Indiana, 1981-90 water years. (Size of the shaded circle is proportional to the load.) 
result from similar relations between concentration and streamflow at these sites. Although concentrations at site WR81 are greater than those at site EW79 at low to medium flows, concentrations are similar at medium to high flows and most of the mass is transported at high flows (fig. 22). Mean annual loads of phosphorus were approximately 25 percent greater at site WR81 than at site EW79, probably because of the greater volumes of municipal effluent (table 6), combined-sewer overflows, and urban runoff discharged to the west fork and because site WR 81 has a larger drainage basin and probably greater volumes of streamflow.

Mean annual nutrient loads were expressed in tons per square mile per year [(tons $\left./ \mathrm{mi}^{2}\right) / \mathrm{yr}$ ] to enable a comparison of loads at monitoring sites with different sized drainage basins (fig. 23). Loads expressed on the basis of unit area are termed "yields." The 95-percent confidence limits for the estimated yields also are shown. Wide confidence limits are caused by a poorly defined relation between concentration and streamflow. Confidence limits are wider at sites with small drainage areas, probably because concentrations and streamflow were much more variable in small basins than in large basins. In addition, samples during high streamflow are more difficult to obtain from small basins. Some of the uncertainty in the load estimates for small basins probably results from greater uncertainty in the concentrations of nutrients at the highest streamflows.

Ammonia yields increased downstream in the upstream reach of the White River (fig. 23), probably because of the successive discharges from municipal sewage-treatment plants and urban runoff in this reach. Ammonia yield was greatest by far at site WR210 [0.64 (tons/ $\left.\left.\mathrm{mi}^{2}\right) / \mathrm{yr}\right]$, downstream from Indianapolis and shows the substantial effect of ammonia discharges from Indianapolis. Ammonia yield at site WR81, approximately $140 \mathrm{mi}$ downstream from Indianapolis, was greater than the yields at monitoring sites upstream from Indianapolis. The large yield at site WR81 indicates that ammonia discharged in Indianapolis was discernible more than $140 \mathrm{mi}$ downstream. Ammonia yields at sites on the East Fork White
River, site FC7, and site MC18 were approximately 0.10 (tons $/ \mathrm{mi}^{2}$ ) $/ \mathrm{yr}$ and were similar to the yield at site WR319, upstream from most of the urban effects in the west fork. Ammonia yields of this magnitude probably indicate the effects of agricultural and other nonpoint sources rather than the urban effects observed in the west fork.

Yields of nitrate were greatest in the small agricultural basins (sites WR319 and MC18), but confidence intervals for these estimates are large and indicate considerable uncertainty in these estimates (fig. 23). The yield of nitrate downstream from Indianapolis [4.9(tons $\left./ \mathrm{mi}^{2}\right) / \mathrm{yr}$ at site WR210] was similar to the yield upstream from Indianapolis [4.8 (tons $\left./ \mathrm{mi}^{2}\right) / \mathrm{yr}$ at site WR248] and indicates that point sources of nitrate are relatively unimportant in the mass transport of nitrate, even at the site most affected by point sources. One of the largest nitrate yields was at site EW168 [5.5 (tons $\left./ \mathrm{mi}^{2}\right) / \mathrm{yr}$, a site with a relatively large drainage area and few point-source inputs. This large yield provides further evidence that nitrate yields in large rivers in the White River Basin generally are controlled by nonpoint sources.

Nitrate yields at monitoring sites on the downstream reaches of the White River and East Fork White River were less [3.6 (tons $/ \mathrm{mi}^{2}$ )/yr at sites WR81, WR46, and EW79] than those on upstream reaches [4.5 to $5.5\left(\right.$ tons $\left./ \mathrm{mi}^{2}\right) / \mathrm{yr}$ at sites WR293, WR248, WR210, and EW168]. Smaller yields downstream probably were caused by dilution by streamflow from forested areas in the downstream reaches of these larger basins (the downstream sites have 70 to 72 percent agricultural land use and 19 to 23 percent forest, whereas the upstream sites have 89 to 91 percent agricultural land use and 1 to 6 percent forest; table 1). Similar nitrate yields at downstream monitoring sites on the more rural east fork and the more urbanized west fork also indicate that the effects of urban discharges in the upstream reach of the west fork did not increase nitrate yields in the downstream reach. Similar nitrate yields at downstream monitoring sites on the east and west forks are additional evidence that nonpoint sources of nitrate mask point sources in terms of the mass transport of nitrate in the White River Basin. 

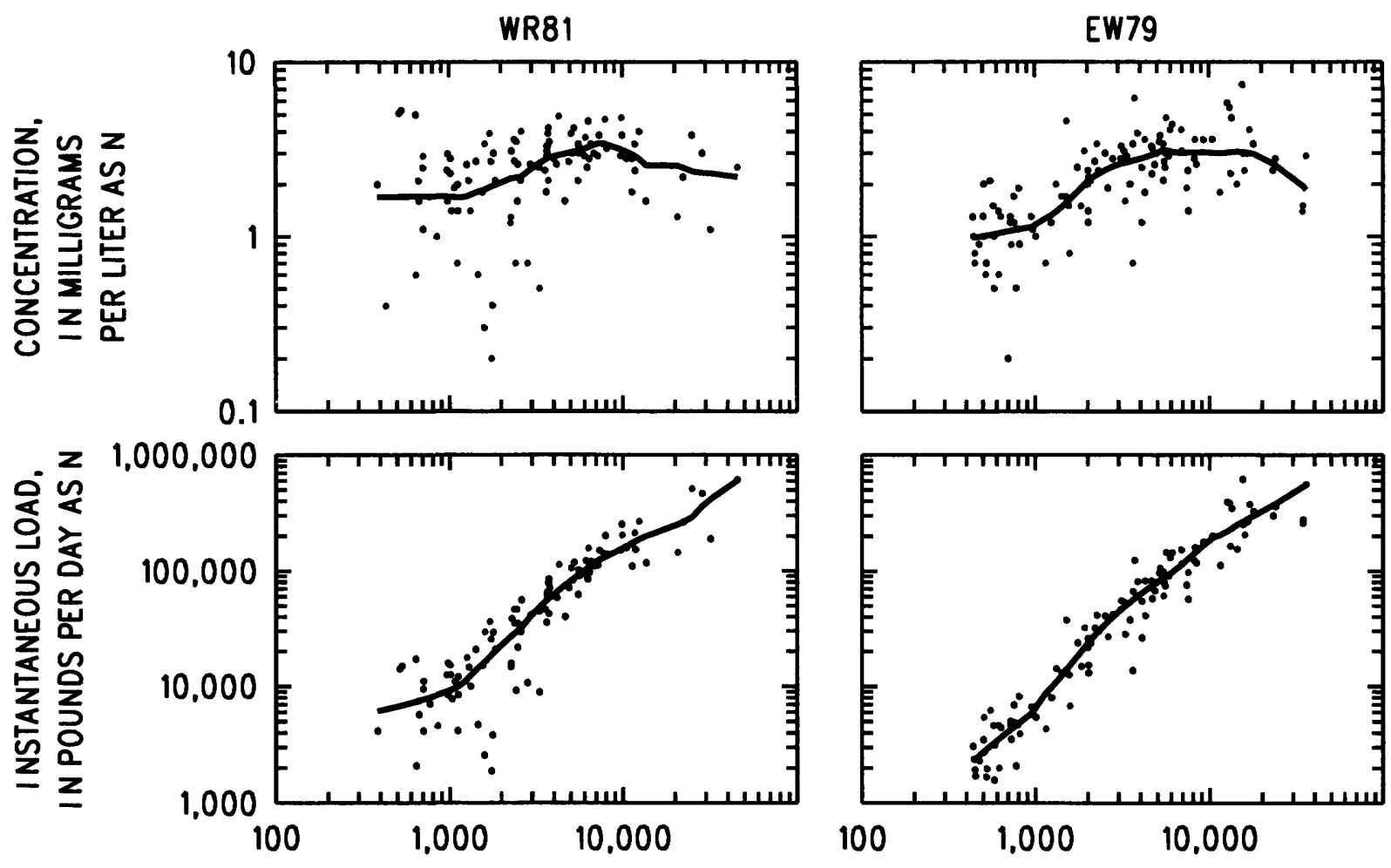

STREAMFLOW, IN CUBIC FEET PER SECOND

Figure 22. Relations of nitrite plus nitrate concentration and load to streamflow at sites WR81 and EW79, 1981-90 water years. (The line in the the scatterplot is a smooth that shows the general relation between concentration or load and streamflow.) 

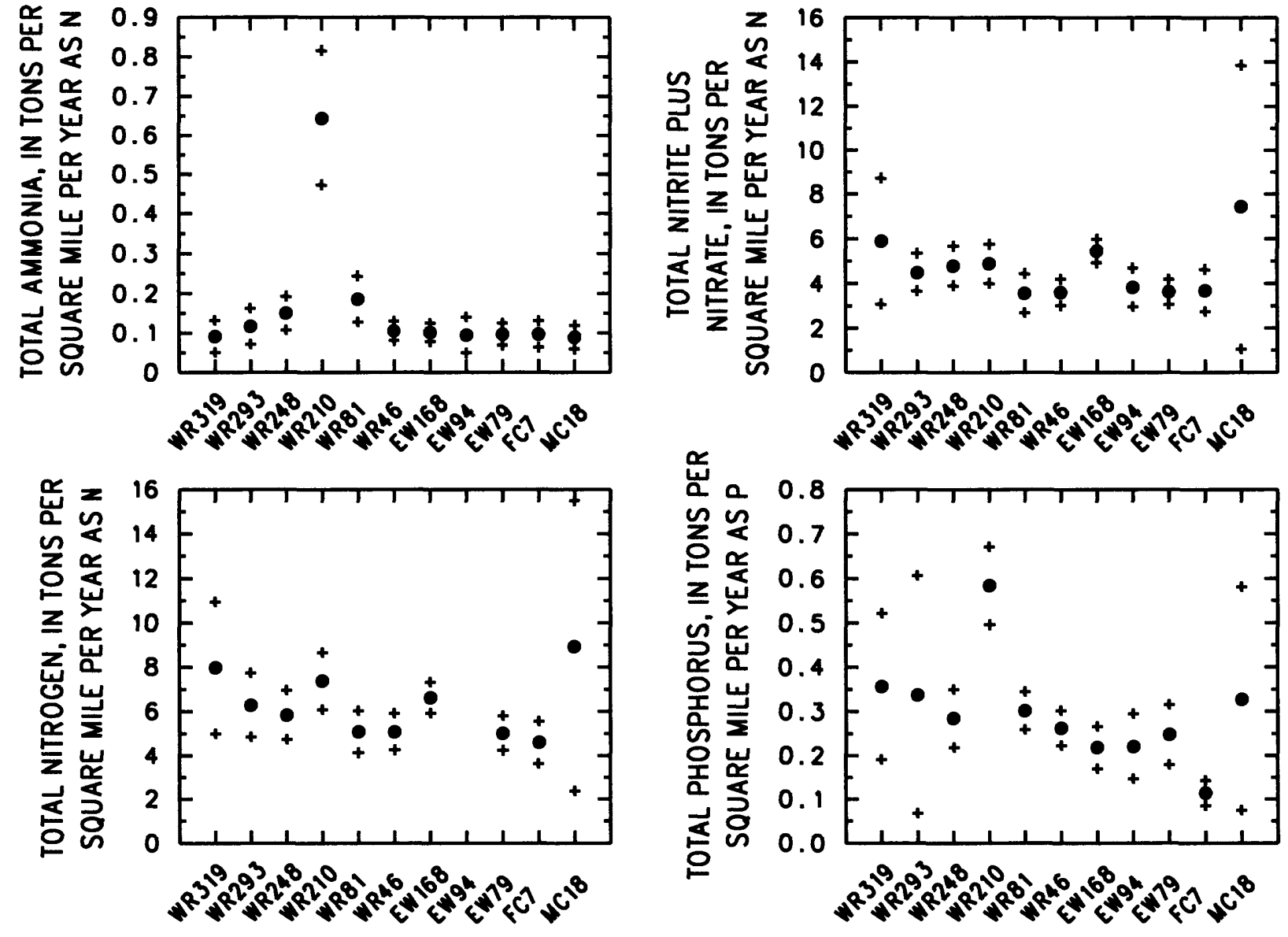

SITE

SITE

\section{EXPLANATION}

- Mean annual yield

+ 95-percent confidence limit for mean annual yield

Figure 23. Mean annual nutrient yields at selected surface-water-quality monitoring sites in the White River Basin, Indiana, 1981-90 water years. 
Total nitrogen yields follow similar patterns to nitrate yields, with the following exception. Compared to nitrate yields, the relatively larger yields of total nitrogen at site WR 210 probably were caused by larger yields of ammonia and organic nitrogen from discharges and runoff in Indianapolis.

Total phosphorus yields in the west fork were greater than those in the east fork because of the greater amount of treated sewage effluent and urban runoff in the west fork. Total phosphorus yield was largest at site WR210 [0.58 (tons $\left.\left./ \mathrm{mi}^{2}\right) / \mathrm{yr}\right]$, and yields decreased downstream (fig. 23). The large yield at site WR210 can be attributed to discharges and urban runoff in Indianapolis. Yields of total phosphorus were approximately 20 percent greater at site WR81 $\left[0.30\right.$ (tons $/ \mathrm{mi}^{2}$ )/yr] than at site EW79 $\left[0.25\left(\right.\right.$ tons $\left.\left./ \mathrm{mi}^{2}\right) / \mathrm{yr}\right]$ and indicate that point sources of phosphorus in the west fork can be discerned over nonpoint sources in terms of mass transport. The smallest yield of total phosphorus was at site FC7 [0.11 (tons $\left.\left./ \mathrm{mi}^{2}\right) / \mathrm{yr}\right]$, probably because Geist Reservoir (fig. 1), located upstream, traps phosphorus adsorbed on suspended sediment.
Nitrogen was transported more readily by surface water than was phosphorus. Although inputs of nutrients to the basin had relatively low ratios of nitrogen to phosphorus $(\mathrm{N}: \mathrm{P}$ ratios of 1.6:1 to $4.4: 1$ ), the ratios of the mean annual yield of nitrogen to phosphorus in rivers were high (table 7). The lowest yield ratio (N:P ratio of 13:1) was at site WR210 and shows the effect of pointsource discharges of phosphorus directly to the White River in Indianapolis. The highest yield ratio (N:P ratio of $30: 1)$ was at site EW168 and probably is representative of high-intensity agriculture and a lack of urban point sources of phosphorus. Similarly, mean annual yields of nitrogen and phosphorus were 24 to 34 percent and 3 to 10 percent of the estimated input, respectively (calculated from data in tables 5 and 6). The largest yield, as a percentage of estimated input, for nitrogen and phosphorus was at site WR210 where point sources of nutrients are discharged directly to the White River. In view of the low rate of phosphorus transport in rivers, the high input of phosphorus to land, the generally inefficient use of phosphorus fertilizers by crops (Brady, 1974, p. 457), and the lack of other pathways of phosphorus loss, phosphorus probably is accumulating in farmland soils but in forms unavailable to crops.

Table 7. Ratio of nitrogen to phosphorus for inputs to selected drainage basins and for mean annual yields at selected surface-water-quality monitoring sites in the White River Basin, Indiana, 1981-90 water years [nd, not determined]

Ratio of nitrogen to phosphorus input or yield

\begin{tabular}{|c|c|c|c|c|c|c|}
\hline \multirow[b]{3}{*}{ Input or yield } & & & & & & \\
\hline & \multicolumn{6}{|c|}{ Water-quallty monitoring site } \\
\hline & WR248 & WR210 & WR81 & WR46 & EW168 & EW79 \\
\hline Municipal sewage & 1.6:1 & 1.6:1 & $1.6: 1$ & $1.6: 1$ & $1.6: 1$ & $1.6: 1$ \\
\hline Industrial discharge & $3.3: 1$ & $3.4: 1$ & $3.5: 1$ & $3.2: 1$ & nd & $2.6: 1$ \\
\hline Atmospheric deposition & nd & nd & nd & nd & nd & nd \\
\hline Commercial fertilizer & $4.4: 1$ & $4.4: 1$ & $4.4: 1$ & $4.4: 1$ & $4.4: 1$ & $4.4: 1$ \\
\hline Farm-animal manure & $2.3: 1$ & $2.3: 1$ & $2.4: 1$ & $2.4: 1$ & nd & $2.3: 1$ \\
\hline Total basin input & $4.1: 1$ & $3.8: 1$ & $4.1: 1$ & $4.2: 1$ & nd & $4.2: 1$ \\
\hline Mean annual yield & $21: 1$ & $13: 1$ & $17: 1$ & $20: 1$ & $30: 1$ & $20: 1$ \\
\hline
\end{tabular}


Because nutrient transport is greatly affected by precipitation, evapotranspiration, and surface runoff (Likens and others, 1977, p. 65-86; Jaworski and others, 1992, p. 93-94), annual yields for dry and wet years were compared (fig. 24). Water year 1988 was selected as the dry year, and water year 1990 was selected as the wet year. Precipitation during the 1988 water year was 5 to 11 in. below normal, and runoff was as much as 9 in. below normal (Glatfelter and others, 1989, p. 3). Rainfall in May 1988 was less than onehalf of normal, and June was the driest of record. Twelve of 20 observation wells reached record low water levels, and many reservoirs approached or reached record low levels (Fowler, 1992, p. 87, 90). Precipitation during water year 1990 was 0 to $10 \mathrm{in}$. above normal, and runoff was 2 to $8 \mathrm{in}$. above normal (Stewart and Nell, 1991, p. 3).

Monthly unit streamflow $\left[\left(\mathrm{ft}^{3} / \mathrm{s}\right) / \mathrm{mi}^{2}\right]$ during the wet water year (1990) at gaging stations in the downstream reaches of the east and west forks was 8 to 12 times greater during November, May, and June and was 2.5 to 6 times greater during October, July, August, and September than during the dry water year (1988). The total volume of water discharged during the wet year, however, only was twice that discharged during the dry year. Annual unit streamflow at the downstream monitoring sites on both forks was the same for the dry year but was about 5 percent greater in the west fork for the wet year.

The pattern of ammonia yields was similar between wet and dry years (fig. 24). Ammonia increased downstream in the upstream reach of the White River in response to urban areas in both years. Ammonia yields during the wet year were 2.1 to 3.5 times larger than during the dry year at monitoring sites in the urbanized reach of the White River at and upstream from site WR210 and at site FC7 in Indianapolis. Increased yields of ammonia during the wet year at the other sites in non-urban areas were less than 1.9 times the yields during the dry year. Because the dry weather rate of discharge from sewage-treatment plants should be similar between years, the larger yields of ammonia at sites in the upstream reach of the White River and at site FC7 during the wet year may have been caused by greater amounts of urban storm runoff treated by sewage-treatment plants and by untreated urban runoff and combined-sewer overflows.

Some or all of the cause of the larger yields of ammonia in the upstream reach of the White River during the wet year may be attributed to a proportionately greater increase in streamflow in the upstream reach during the wet year. Annual streamflow during the wet year was 2.8 to 3.2 times greater than the dry year in the upstream reach of the White River, whereas at the other sites annual streamflow during the wet year only was 1.5 to 2.2 times greater than the dry year. The cause of greater streamflows in the upstream reach of the White River is not known but could be attributed to greater runoff from urban areas. If so, urban runoff and combined-sewer overflows still would be the cause of the larger yield of ammonia.

Although the ammonia yield at site WR210 during the wet year [0.61 (tons $/ \mathrm{mi}^{2}$ )/yr, fig. 24] was similar to the mean yield for water years 1981-90 [0.64 (tons $/ \mathrm{mi}^{2}$ )/yr, fig. 23], the yield at site WR210 during the wet year occurred after improvements were made to the Indianapolis sewage-treatment plants in 1982. Mean ammonia yield for water years 1981-90 was affected by discharges containing high concentrations of ammonia before improvements were made to the plants.

Yields of nitrate showed marked differences between wet and dry years. During the dry year, yields of nitrate increased downstream from urban areas at several monitoring sites in the upstream reach of the White River, probably because of discharges from sewage-treatment plants. Nitrate yield at site WR210 [3.5 (tons $\left.\left./ \mathrm{mi}^{2}\right) / \mathrm{yr}\right]$ during the dry year was the largest in the White River (fig. 24). Nitrate yields during the wet year were 1.4 to 3.7 times the yields during the dry year. Nitrate yields at sites at and upstream from site WR248 on the White River were 3.0 to 3.7 times the yield of the dry year, whereas sites on the East Fork White River and at and downstream from site WR210 on the White River only were 1.8 to 1.9 times the dry year yield. The cause of the 

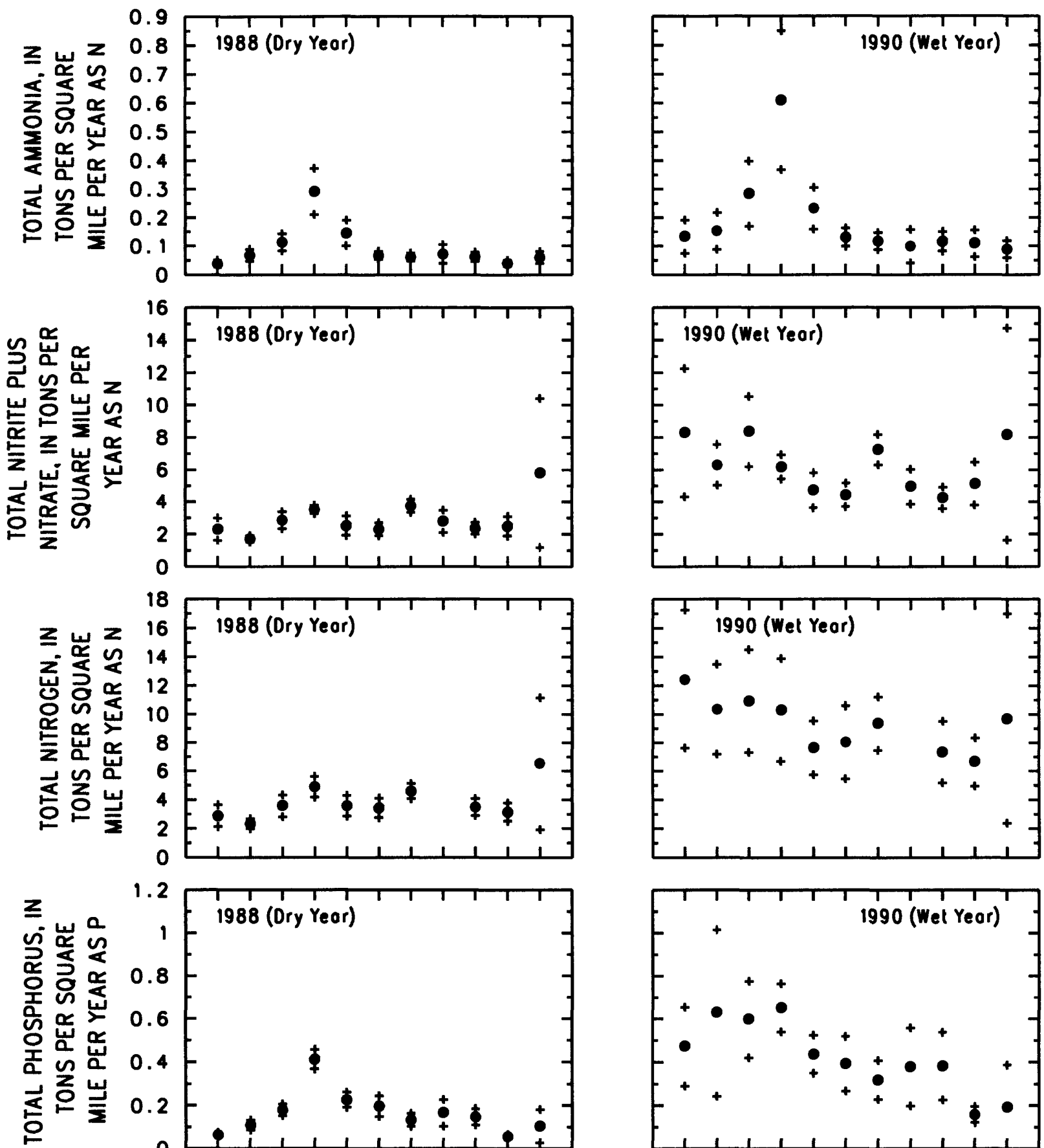

1.2
1
0.8
0.6
0.4
0.2
0
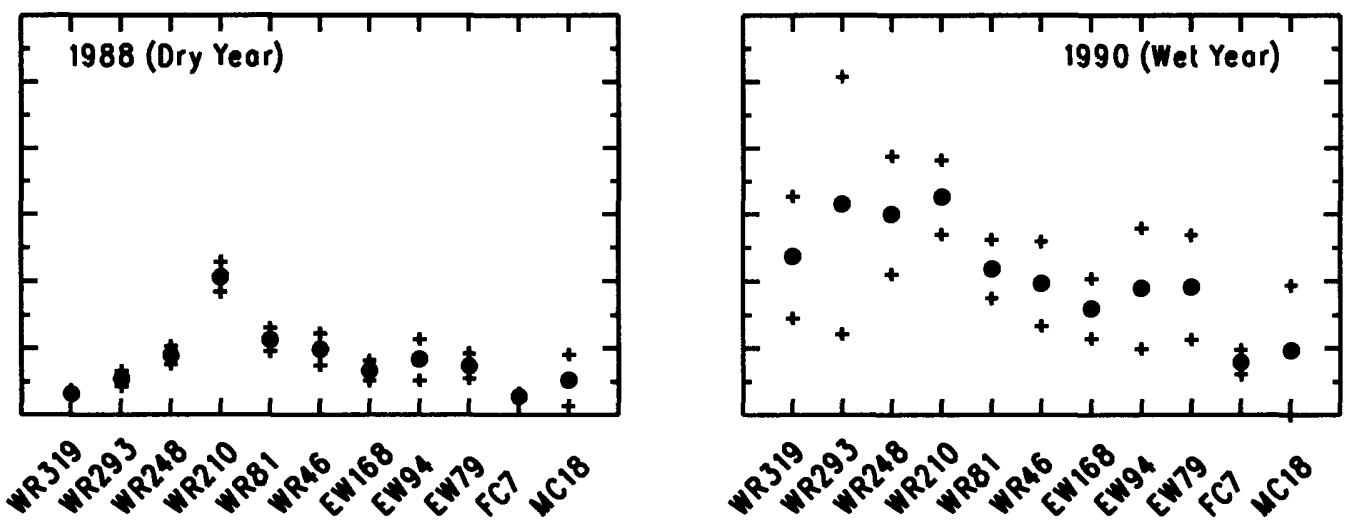

SITE

EXPLANATION

SITE

- Annual yield

+ 95-percent confidence limit for onnual yield

Figure 24. Annual nutrient yields during dry (1988 water year) and wet (1990 water year) years at selected surface-water-quality monitoring sites in the White River Basin, Indiana. 
higher increases in nitrate yields at upstream sites on the White River is not known but may have been caused by urban runoff and combinedsewer overflows or by higher unit streamflows in these smaller basins. The yield at site WR210 [6.2 (tons $\left./ \mathrm{mi}^{2}\right) / \mathrm{yr}$ ] was less than the nitrate yields upstream and showed the importance of nonpoint sources of nitrate during the wet year.

Patterns in yields of total nitrogen between wet and dry years were similar to yields of nitrate because nitrate composes 65 to 80 percent of the yield of total nitrogen at most monitoring sites.

Yields of total phosphorus also showed marked differences between wet and dry years. During the dry year, yields of phosphorus exhibited similar patterns to yields of ammonia (fig. 24) and showed the importance of point sources of phosphorus. Phosphorus yields during the wet year were 1.6 to 7.5 times greater than the yields during the dry year and showed the importance of nonpoint sources during the wet year. As with yields of ammonia and nitrate, the greatest increases in yields of phosphorus occurred in the upstream reach of the White River (3.3 to 7.5 times higher than the yield during the dry year), probably for similar reasons. Yields of total phosphorus during the wet year were 2.3 to 2.6 times greater than yields during the dry year at sites on the East Fork White River but only were 1.6 to 1.9 greater during the wet year at sites WR210 and WR81, respectively. Smaller relative increases in yields during the wet year at sites WR210 and WR81 were a result of high yields caused by point sources during the dry year.

Phosphorus yields exhibited relatively greater increases between wet and dry years than did yields of ammonia or nitrate. The relatively greater increases in phosphorus yields during the wet year may indicate that surface runoff was more important for phosphorus transport than for ammonia or nitrate transport (Baker and others, 1985 , p. 202).
Estimated mean annual atmospheric deposition (precipitation and dry fallout) of ammonia and nitrate in the White River Basin was 0.71 and 2.24 (tons $/ \mathrm{mi}^{2}$ ) $/ \mathrm{yr}$, respectively. These estimates are similar to estimates of ammonia deposition [0.62 to 1.04 (tons $/ \mathrm{mi}^{2}$ )/yr] but slightly more than estimates of nitrate deposition $[0.42$ to 2.09 (tons $\left.\left./ \mathrm{mi}^{2}\right) / \mathrm{yr}\right]$ in south-central Indiana for a 3-month period in 1980-81 (Peters and Bonelli, 1982 , p. 31, 37). Mean annual yield of ammonia at site WR46 was 0.10 (tons $/ \mathrm{mi}^{2}$ )/yr. Because seven times more ammonia enters the basin by atmospheric deposition than leaves by streamflow, ammonia was removed or stored in the basin. Likely mechanisms for ammonia removal and storage were uptake by vegetation and bacteria and nitrification to nitrate. Mean annual yield of nitrate at site WR46 was 3.6 (tons $/ \mathrm{mi}^{2}$ )/yr. Because more nitrate leaves the basin by streamflow than enters the basin as atmospheric deposition, other sources of nitrogen were contributing to the nitrate in streamflow. Likely sources of nitrogen were nitrification of ammonia in water and soils; commercial fertilizers; human and animal wastes; mineralization of organic nitrogen in soils, sediments, and vegetation; and fixation of atmospheric nitrogen by plants, algae, and bacteria.

\section{Relation of Nutrient Concentrations in Base Flow to Hydrogeomorphic Region}

Water-quality samples were collected from 48 small streams during an extended period of base flow in March 1992 (fig. 8). Although discharges of nutrients by farmers and others upstream from the sampling sites were possible, base-flow samples were expected to approximate the quality of shallow ground water that sustains base flow. Nutrient concentrations differed significantly among the hydrogeomorphic regions used in this assessment (fig. 25).

Median concentrations of dissolved ammonia were highest in streams draining the glacial lowland $(0.04 \mathrm{mg} / \mathrm{L})$ and lowest in streams draining 


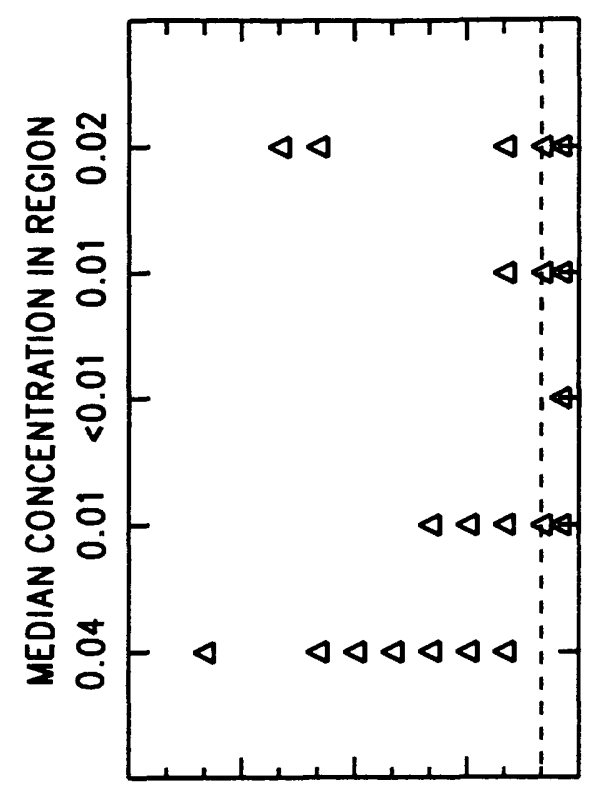

$\begin{array}{lllll}\approx & 9 & 0 & m & 0 \\ 0 & 0 & 0 & 0 & 0\end{array}$ N S Y YII ע ע SW SY NI 'JIIYIIN 03^TOSSIO

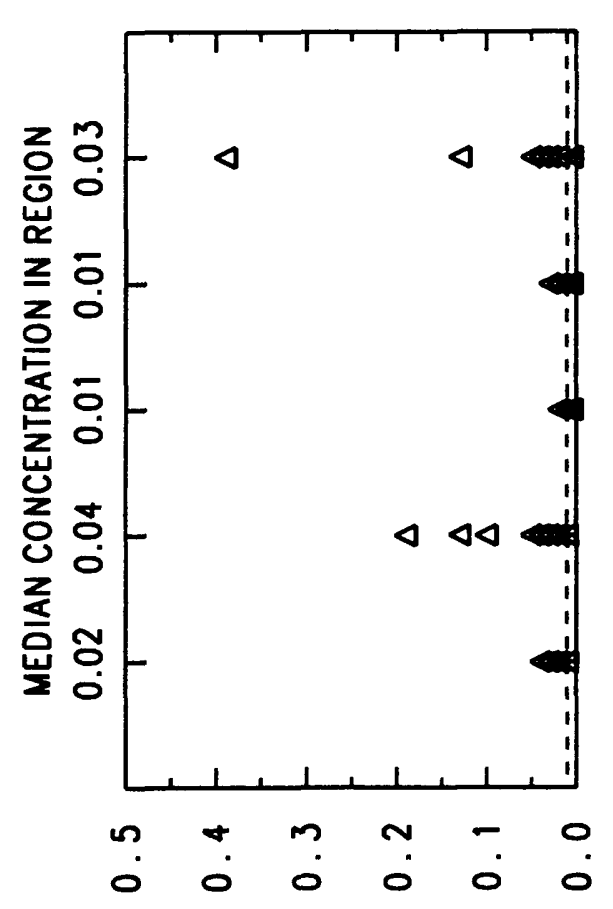

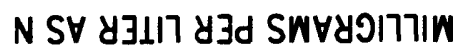
NI 'VINOWW 03 OTOSSIO

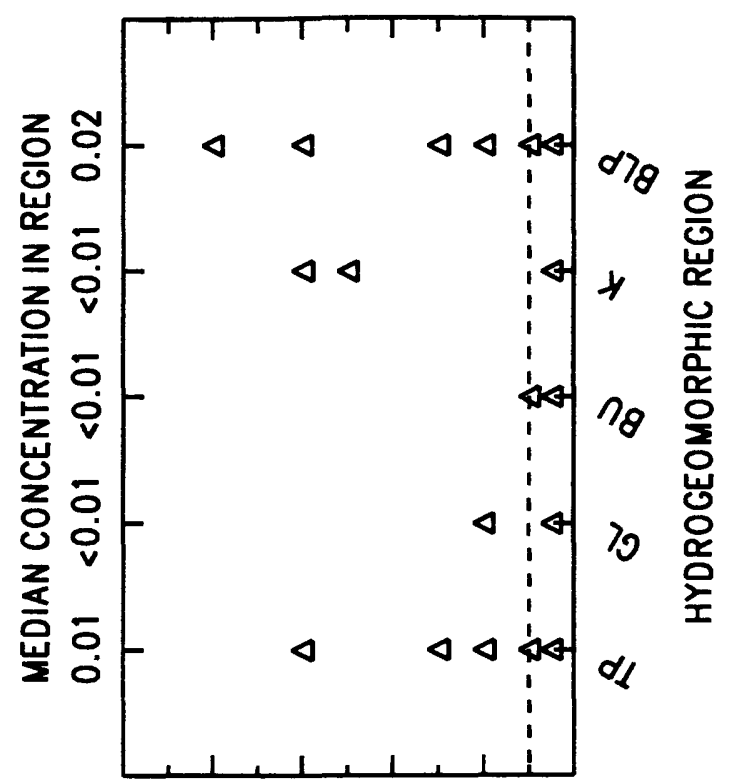

이융 0000000 d SV Y 3117 y 'SNYOHdSOHd 0JATOSSIO
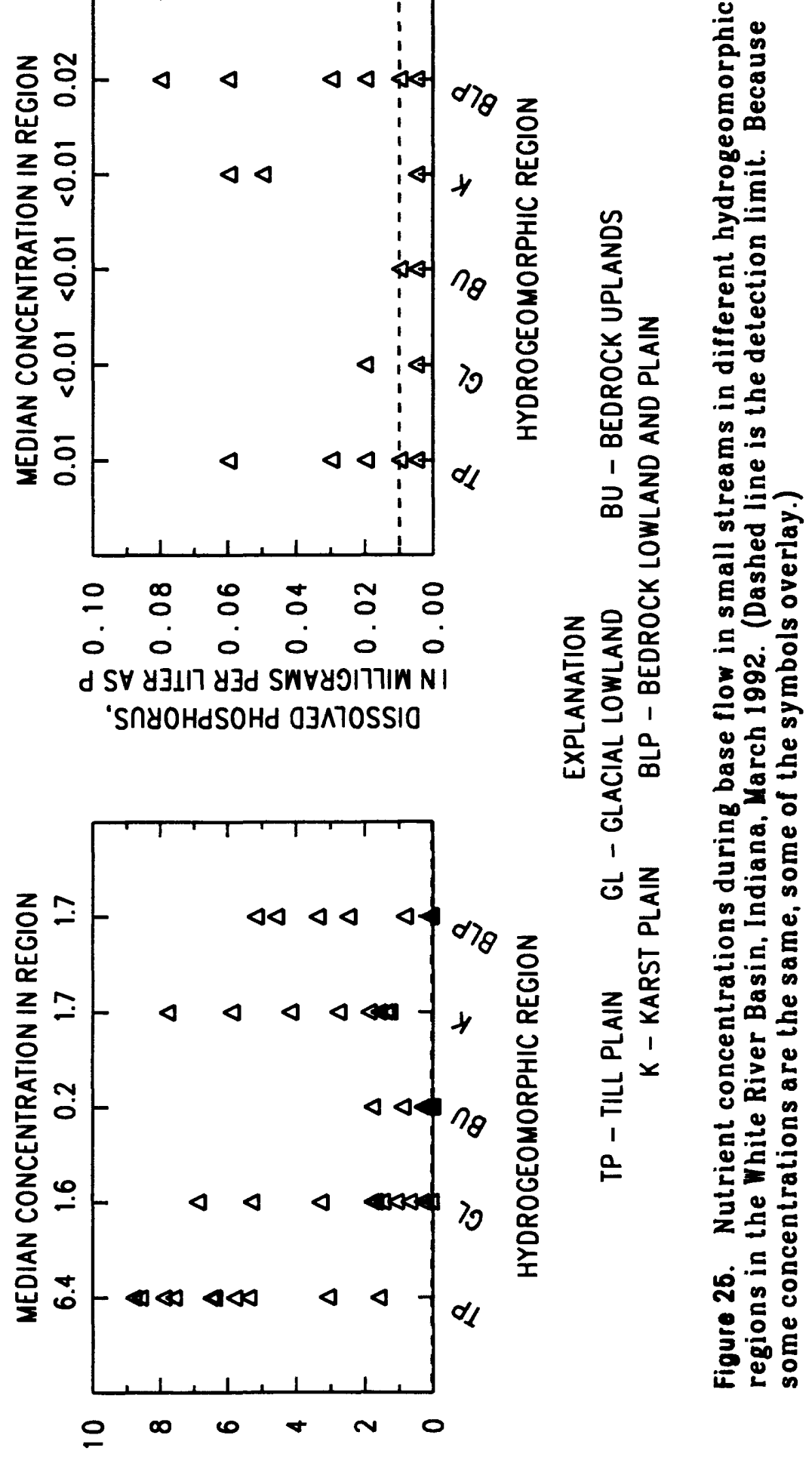

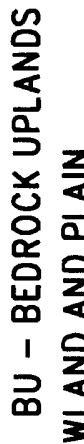

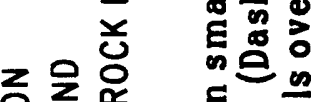

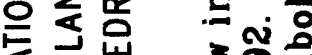

主岗

《 1 के

뭊

음용

$\frac{a}{0}$

过

1

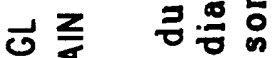

वे 동

$z$

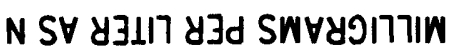

NI 'JIVYIIN Sก7d

JIIYIIN 03ATOSSIO

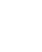

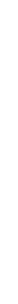


the bedrock uplands $(0.01 \mathrm{mg} / \mathrm{L})$ and the karst plain $(0.01 \mathrm{mg} / \mathrm{L})$. Median concentrations of ammonia in the bedrock uplands and the karst plain were significantly lower than those in the glacial lowland and the bedrock lowland and plain (fig. 25). The low concentrations of ammonia in the bedrock uplands may be attributed to the small amounts of agricultural and urban land uses in these basins. Higher concentrations of ammonia in the glacial lowland and the bedrock lowland and plain regions may not have been related to groundwater seepage in these regions but may have been related to the input of wastes from farm animals. Ammonia $\left(\mathrm{NH}_{3}\right)$, when dissolved in water, forms the cation ammonium $\left(\mathrm{NH}_{4}{ }^{+}\right)$that is strongly adsorbed to mineral surfaces in soils (Hem, 1985, p. 124) and resists leaching to ground water. Because ammonium resists movement to ground water and because commercial fertilizers usually are not applied to farm fields until April, relatively high concentrations of ammonia in some small streams during March base-flow conditions might be attributed to direct inputs from animals grazing near streams or from surface drainage from barnyards or feedlots near streams.

Median concentrations of dissolved nitrite were highest in streams draining the till plain $(0.04 \mathrm{mg} / \mathrm{L})$ and lowest in streams draining the bedrock uplands $(<0.01 \mathrm{mg} / \mathrm{L})$. Median concentrations of nitrite in the bedrock uplands and karst plain were significantly lower than those in the till plain and the bedrock lowland and plain, and median concentrations of nitrite in the glacial lowland were significantly lower than those in the till plain (fig. 25). Higher concentrations of nitrite in the till plain may have been caused by denitrification (biochemical conversion of nitrate to nitrite and nitrite to nitrogen gas). Reducing conditions favorable to denitrification were expected in the ground-water system of the till plain where the low permeability of till causes slow rates of flow and low dissolved-oxygen concentrations. Because the surficial materials in the other regions are thinner (bedrock uplands and bedrock lowland and plains) or more permeable (glacial lowland), higher concentrations of dissolved oxygen, which inhibit denitrification, were expected in the aquifers in the other hydrogeomorphic regions.

Median concentrations of dissolved nitrate were highest in the till plain $(6.4 \mathrm{mg} / \mathrm{L})$ and lowest in the bedrock uplands $(0.2 \mathrm{mg} / \mathrm{L})$. Median concentrations of nitrate in the glacial lowland and in the bedrock lowland and plain were significantly lower than the median nitrate concentration in the till plain. Median concentrations of nitrate in the bedrock uplands were significantly lower than those in the till plain, karst plain, and glacial lowland (fig. 25). Low concentrations of nitrate in the bedrock uplands probably were caused by the small amount of agricultural and urban land uses and the large amount of forest in these small basins. On the basis of the greater permeability of surficial materials, higher nitrate concentrations were expected in base flow from the glacial lowland and karst plain regions. The till plain, however, had the highest concentrations of nitrate in base flow. High nitrate concentrations in the till plain may have been caused by high concentrations of nitrate in drainage from buried agricultural tile drains rather than by inflow from the shallow ground-water flow systems. Although tile drains occur in all hydrogeomorphic regions of the basin, tile drains are expected to occur more frequently in the relatively flat till plain region (William Hosteter, Soil Scientist, U.S. Natural Resources Conservation Service, oral commun., September 1995). Concentrations of nitrate in tile drainage from an agricultural research site in the bedrock lowland and plain region were seldom less than $10 \mathrm{mg} / \mathrm{L}$ and commonly 20 to $30 \mathrm{mg} / \mathrm{L}$ (Kladivko and others, 1991, p. 268).

Median concentrations of dissolved phosphorus were highest in the bedrock lowland and plain $(0.02 \mathrm{mg} / \mathrm{L})$ and lowest in the glacial lowland, bedrock uplands, and karst plain $(<0.01 \mathrm{mg} / \mathrm{L})$. Median concentrations of phosphorus were significantly higher in the bedrock 
lowland and plain than in the glacial lowland or the bedrock uplands. The reasons for higher concentrations of dissolved phosphorus in the bedrock lowland and plain region than in other regions dominated by agricultural land use are not known.

\section{Ground Water}

The major factors affecting nutrient concentrations in ground water investigated in this assessment are aquifer type, well depth, well type, and season. As discussed in the section "Distribution of Ground-Water Samples by Aquifer Type, Hydrogeomorphic Region, and Well Type," the effect of hydrogeomorphic region on groundwater quality could not be assessed directly for all regions. Results for the till, outwash, and karst aquifers, however, probably are representative of ground-water quality in the till plain, fluvial deposits, and karst plain hydrogeomorphic regions, respectively.

\section{Relation of Nutrient Concentrations to Aquifer Type and Well Depth}

Ground-water samples were collected from 101 wells in the White River Basin (fig. 9). The median concentration of ammonia in the till aquifers was $0.25 \mathrm{mg} / \mathrm{L}$, whereas median concentrations in the outwash, bedrock, and karst aquifers were less than $0.1 \mathrm{mg} / \mathrm{L}$ (fig. 26). The high concentrations of ammonia in the buried sand and gravel lenses that compose the till aquifers were not expected because ammonia is strongly adsorbed to mineral surfaces (Hem, 1985, p. 124) and is considered to be relatively immobile in ground water (Freeze and Cherry, 1979, p. 415; Hallberg and Keeney, 1993, p. 298). The predominant form of ammonia dissolved in water is ammonium, which tends to adsorb by cation exchange to clay particles in the soil (Brady, 1974, p. 99). In addition, the till aquifer is thought to have low concentrations of dissolved oxygen. Therefore, high ammonia concentrations probably were not caused by the oxidation of organic nitrogen dissolved in the water or contained in the sediments of the aquifer. Ammonification (formation of ammonia from organic nitrogen) and nitrification are processes that usually occur in the soil rather than in aquifers (Freeze and Cherry, 1979, p. 413). High concentrations of ammonia in the till aquifers may have been caused by the biochemical reduction of nitrate to ammonia. Nitrate reduction to ammonia, like dentrification of nitrate to nitrogen gas, occurs under conditions of low dissolved oxygen but is favored over denitrification under highly reducing conditions (Hallberg and Keeney, 1993, p. 299) when nitrate concentrations are low and dissolved organic-carbon concentrations are high (Korom, 1992, p. 1659).

The lowest concentrations of ammonia were measured in the outwash aquifers. These aquifers are permeable, often are unconfined, and typically have shallow water tables. Low concentrations in the outwash aquifers may have been caused by the high concentrations of oxygen in these aquifers which inhibit biochemical reduction of nitrate to ammonia.

Although ammonia was higher in the till aquifers, concentrations of nitrate were lowest in the till aquifers (fig. 26). Low concentrations of nitrate in the till aquifers probably were caused by reduced percolation (recharge) of nitrate in water from soils through the tight till and by denitrification (biochemical conversion of nitrate to nitrite and nitrite to nitrogen gas) or biochemical reduction of nitrate to ammonia in the aquifer.

The median concentration of nitrate was highest in the karst aquifers $(2.0 \mathrm{mg} / \mathrm{L})$. Karst aquifers have been considered vulnerable to contamination by surface runoff to sinkholes (White, 1993, p. 487). Because overland flow typically has higher concentrations of ammonia and organic nitrogen than nitrate (Hallberg and Keeney, 1993, p. 300), higher concentrations of nitrate in the karst aquifers may not have been caused by the rapid transport of surface runoff to ground water by sinkholes and other solution features. Some studies of karst systems have shown the importance of infiltration rather than sinkholes and conduit flow as the primary mechanism for nitrate contamination of karst aquifers 

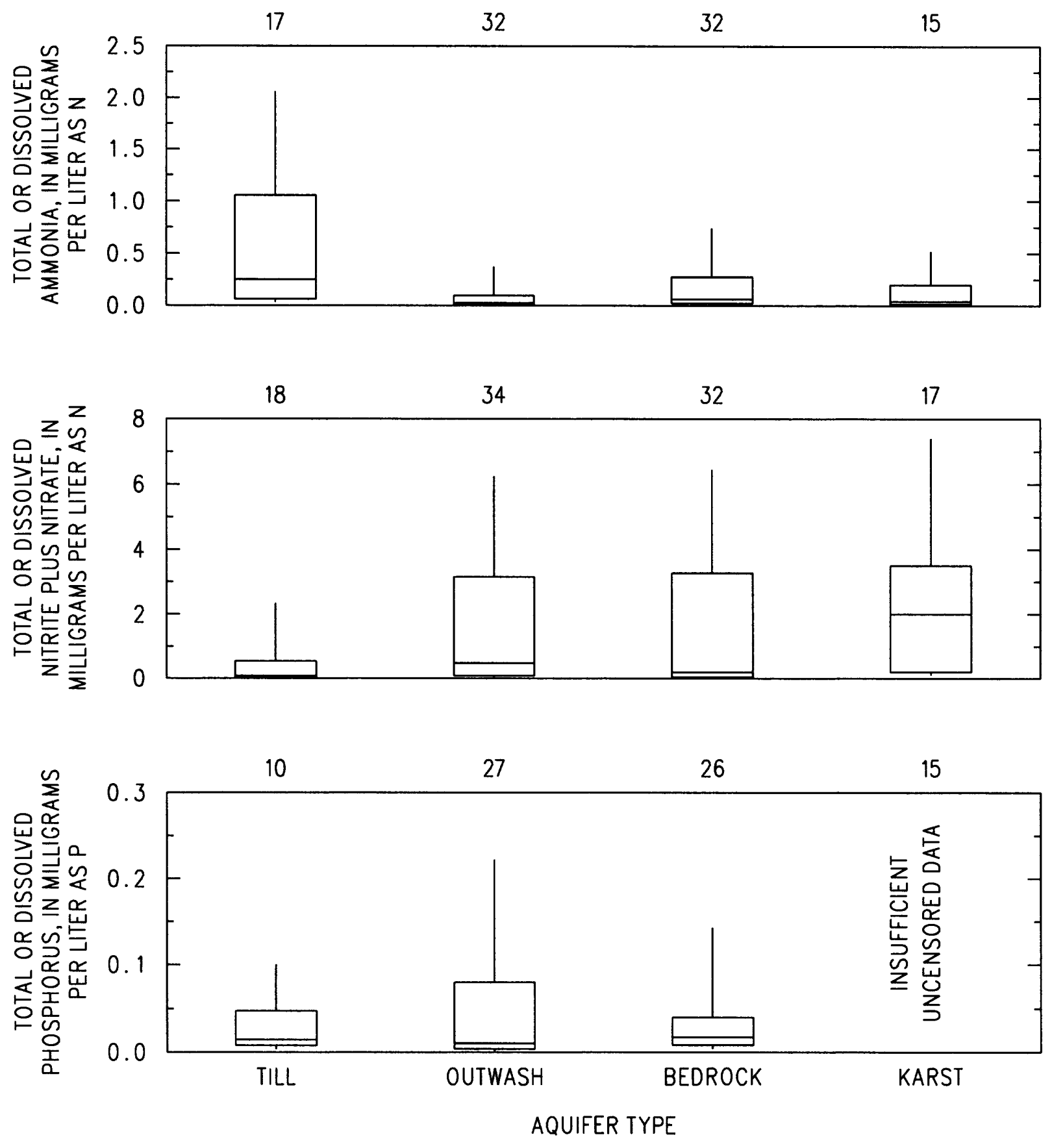

Figure 26. Nutrient concentrations in wells in different types of aquifers in the White River Basin, Indiana, 1987-91. 
(Hallberg and others, 1985; Scanlon, 1990). Wells and Krothe (1989), in a study of a karst area in the White River Basin, concluded that macropores in the clayey mantle covering the karst aquifer were responsible for nitrate contamination and that septic systems, rather than commercial fertilizers, were the sources of most of the nitrate. Even if infiltration or percolation through macropores is the primary mechanism delivering nitrate to the surface of the karst aquifers, flow through solution features may be the primary factor in the distribution of nitrate in the aquifers.

Median concentrations of phosphorus were at or less than the detection limit $(0.03 \mathrm{mg} / \mathrm{L})$ for all aquifer types. Most organic forms of phosphorus are relatively insoluble in soils or are immobilized by soil bacteria; whereas soluble, inorganic forms of phosphorus applied as fertilizers are rapidly fixed in calcium, iron, aluminum, and manganese complexes (Brady, 1974, p. 456-471). Because phosphorus is tightly bound in soils and is unlikely to leach under most soil conditions, high concentrations in aquifers were not expected.

Concentrations of ammonia generally were higher in deep wells than in shallow wells, whereas concentrations of nitrate were higher in shallow wells than in deep wells. Although many deep wells had low concentrations of ammonia, most of the wells with high concentrations of ammonia (greater than $0.7 \mathrm{mg} / \mathrm{L}$ ) were in till or bedrock aquifers greater than $100 \mathrm{ft}$ deep (fig. 27). Analysis of the entire data set showed that ammonia was positively correlated to well depth (Kendall tau-b correlation coefficient $=0.22, p=0.0041$ ). Positive correlations between ammonia and depth were statistically significant for the till and bedrock aquifers. Positive correlations for the other types of aquifers were not statistically significant. High ammonia concentrations at depth probably were not caused by the downward movement of ammonia from the land surface because shallow wells also would have had high concentrations of ammonia and because ionized ammonia (ammonium) resists leaching. Deep ground water usually has less oxygen than shallow ground water, and the high concentrations of ammonia at depth may have been caused by the biochemical reduction of nitrate to ammonia.

Analysis of the entire data set showed that nitrate was negatively correlated to well depth (Kendall tau-b correlation coefficient $=-0.14$, $\mathrm{p}=0.058$ ). The only statistically significant negative correlation between nitrate and depth was for the bedrock aquifer. Negative correlations for the other types of aquifers were not statistically significant. High concentrations of nitrate in shallow wells is indicative of nonpoint-source pollution of ground water by surface-derived pollutants (Hallberg and Keeney, 1993, p. 309). Lower concentrations of nitrate in deep wells may have been caused by deep flow paths that facilitate nitrate-removal processes (denitrification or nitrate reduction) or by dilution by mixing with deeper, older ground water. The deepest wells with high concentrations of nitrate were in karst aquifers (fig. 27) and probably indicate that solution features enable nitrate and oxygen to penetrate deeper into karst aquifers than into the other aquifer types.

\section{Concentrations of phosphorus were not} correlated to well depth for the entire data set or for individual aquifers. Most of the high concentrations of phosphorus were measured in outwash and bedrock aquifers (fig. 27). The cause of the high concentrations of phosphorus in some wells is not known. Septic systems are a potential source of phosphorus. In addition, high concentrations might be related to sampleprocessing techniques. Most of the ground-water samples used for this assessment were not filtered before analysis. Perhaps the high concentrations of phosphorus in some wells can be attributed to particles of aquifer material or other solids suspended in the water sample. 

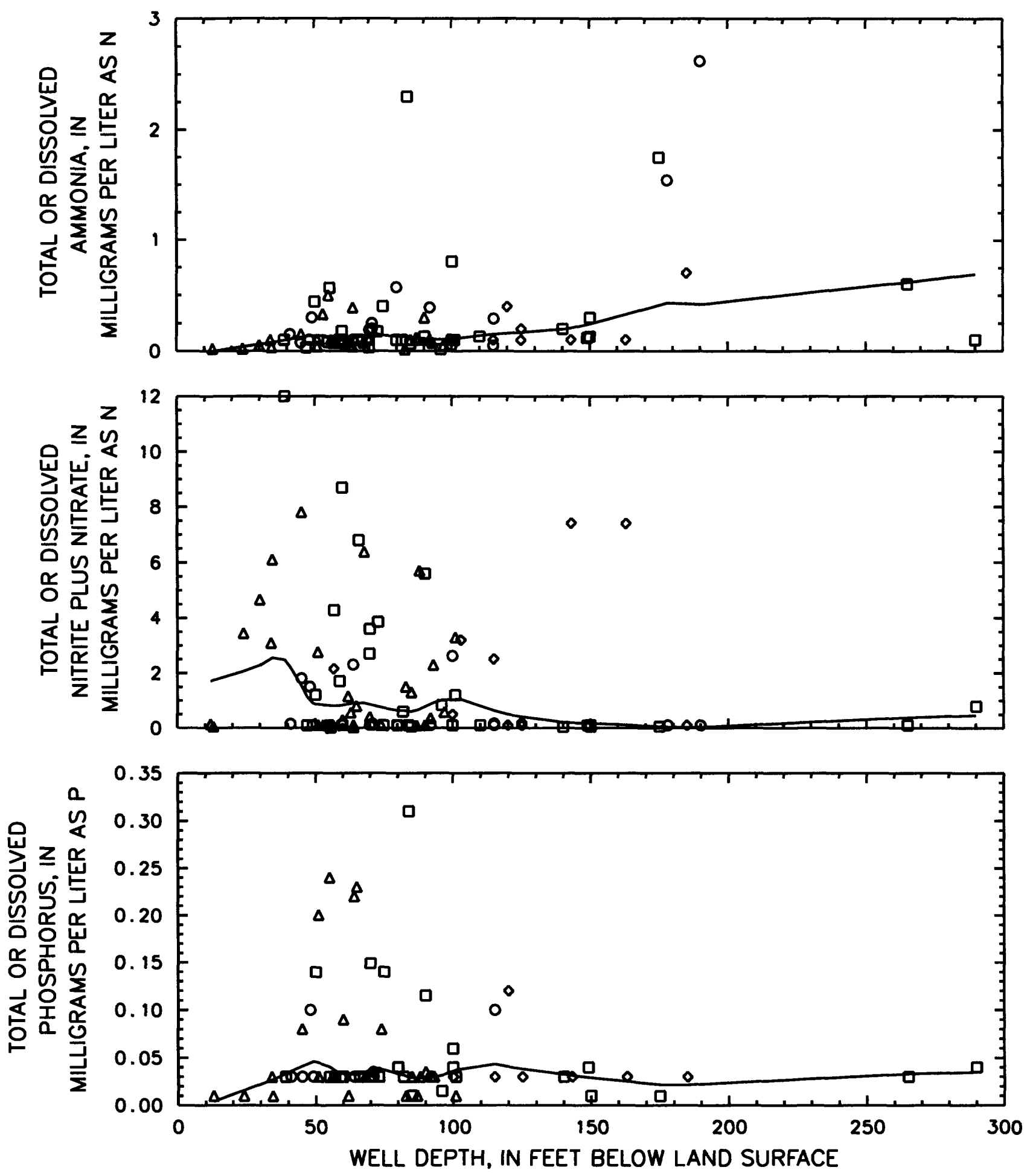

\section{EXPLANATION}

$$
\begin{array}{cccc}
0 \text { Tili } \\
\text { oquilers } & \Delta \begin{array}{c}
\text { Outwosh } \\
\text { oquilers }
\end{array} & \begin{array}{c}
\text { Bedrock } \\
\text { oquilers }
\end{array} & \begin{array}{l}
\text { Korst } \\
\text { oquilers }
\end{array}
\end{array}
$$

Figure 27. Relation of nutrient concentrations to well depth in the White River Basin, Indiana, 1987-91. (The line in the scatterplot is a smooth that shows the general relation between concentration and depth.) 


\section{Relation of Nutrient Concentrations to Well Type and Season}

Median concentrations of ammonia and total phosphorus were equal to or less than detection limits for all well types. Median concentrations of nitrate were highest in the community public water-supply wells $(0.7 \mathrm{mg} / \mathrm{L})$ and lowest in the observation wells $(0.1 \mathrm{mg} / \mathrm{L})$. The reason for the difference in concentrations of nitrate is not known but is not clearly related to the aquifer types supplying these wells. Outwash aquifers were the most common aquifer type for the community public water-supply wells (48 percent) and the observation wells (67 percent). Even within this single aquifer type, median concentrations of nitrate were highest in the community public water-supply wells $(0.7 \mathrm{mg} / \mathrm{L})$ and lowest in the observation wells $(0.1 \mathrm{mg} / \mathrm{L})$.

Only one measurement of nitrate exceeded the U.S. Environmental Protection Agency Maximum Contaminant Level of $10 \mathrm{mg} / \mathrm{L}$. This measurement was from a domestic well in bedrock $39 \mathrm{ft}$ deep.

Paired water-quality samples from 25 wells were used to investigate seasonal changes in ground-water quality. Samples were collected in March and again in June, July, or August the same year. Samples collected during March were used to characterize ground-water quality during the dormant season, whereas those collected during June, July, or August were used to characterize groundwater quality during the growing season. Eighteen wells ( 5 in till, 8 in outwash, 4 in bedrock, and 1 in karst aquifers) were sampled in 1988, and 11 ( 7 in outwash and 4 in bedrock aquifers) were sampled in 1991. Four of the outwash wells were sampled both years.

No consistent seasonal variation in groundwater quality was identified by comparing paired water samples. Nutrient concentrations were higher during the dormant season in about half of the wells but were higher during the growing season in the remaining wells. In some cases, substantial differences in nutrient concentrations between growing and dormant seasons were observed (some concentrations differed by more than 150 percent). These differences between paired water samples show that ground-water quality does change, but the mechanisms responsible for the change could not be determined in this assessment. Seasonal variations in nutrient concentrations in ground water most likely would be exhibited near the water table in shallow, permeable aquifers. Many of the wells used in the assessment of seasonal variations were deep and probably obscured typical seasonal variations in shallow ground water.

\section{CONCEPTUAL MODEL OF THE FACTORS AFFECTING NUTRIENTS IN THE WHITE RIVER BASIN}

Many natural and human factors affect the spatial and temporal variations in the concentrations of nutrients in the environment. This section presents a conceptual model of the major factors that affect nutrient concentrations in surface and ground water and reflects our current understanding of and assumptions about the major processes controlling nutrient concentrations and transport in the White River Basin. The main uses of the model are (1) to develop hypotheses concerning important natural and human factors and processes and their hydrologic effects, (2) to aid the design of data-collection networks to meet the goals of the NAWQA Program, and (3) to provide a framework for interpreting water-quality data. The conceptual model developed from this assessment of water quality will be refined or changed as hypotheses are tested and found to be in agreement with or opposition to the model.

The White River Basin was divided into areas of similar natural characteristics, termed "hydrogeomorphic regions," that integrate most of the major natural factors (geology, soils, vegetation, and landforms) that affect water quality. Hydrogeomorphic regions in the conceptual model are the till plain, glacial lowland, bedrock uplands, karst plain, bedrock lowland and plain, and fluvial 
deposits (for ground water only). With respect to natural factors, the major differences among regions are related to the thickness, permeability, slope, drainage, fertility, and susceptibility to erosion of the soils and surficial geologic materials that are typical of the regions. Major human factors that affect water quality are grouped under the term "land use." Land uses considered in the conceptual model are forest, agriculture, urban, and coal mining.

The shallow, unconsolidated aquifers of the hydrogeomorphic regions differ along a continuum in our conceptual model. Till plain and fluvial deposits aquifers are end members in the continuum, and unconsolidated aquifers of the other regions are in between. In the till plain, thick clayey or loamy till confines buried sand lenses. Downward percolation of water from the land surface is reduced, and lateral flow predominates. Permeability is low and flow rates are slow. Low oxygen concentrations (reducing conditions) are expected in the buried sand lenses (till aquifers). Because of reducing conditions, denitrification is expected to cause low concentrations of nitrate in till aquifers. Outwash and alluvial aquifers in the fluvial deposits region are radically different from the aquifers in the till plain. Water generally is unconfined and near the land surface; aquifer material is at or near the land surface and is highly permeable. Downward percolation of water at the land surface is enhanced, and flow rates are rapid. High oxygen concentrations in ground water are expected. Because of enhanced downward percolation, shallow water tables, and oxidizing conditions, much higher concentrations of nitrate are expected in aquifers of the fluvial deposits region. Unconsolidated aquifers in the glacial lowland are expected to function more like those in the fluvial deposits region, and unconsolidated aquifers in the bedrock lowland and plain are expected to function more like those in the till plain.

Few unconsolidated aquifers occur in the bedrock uplands or the karst plain. In these regions, shallow bedrock aquifers are important. Bedrock aquifers in the bedrock uplands have low yields and slow flow rates and are overlain by bedrock of low permeability. Because of the low permeability of the bedrock and the large amounts of forest in this region, low concentrations of nitrate are expected in the aquifers of the bedrock upland. Bedrock aquifers in the karst plain have rapid flow rates and are overlain by sinkholes, solution features, and macropores in the surficial material. We believe these characteristics result in a well-connected surface- and ground-water system that allows the rapid movement of surface water to ground water. Because of the hydraulically well-connected surface- and ground-water systems and the large amounts of agricultural land use in the karst plain, high concentrations of nitrate are expected in the ground water. Seasonal or short-term temporal variations in ground-water quality are expected to be more pronounced in aquifers in the karst plain, fluvial deposits, and glacial lowland than in the till plain, bedrock uplands, and bedrock lowland and plains. Seasonal variations are expected to be more pronounced in shallow aquifers than in deep aquifers and more pronounced where overlying materials are relatively permeable.

Because ammonia is present as the cation (ammonium) in most soil solutions and is adsorbed on soil particles and because ammonia can be nitrified to nitrate in the unsaturated zone, percolation of ammonia to most aquifers is not expected in the conceptual model. Phosphorus also is strongly adsorbed to soils, and percolation to ground water is not expected. Movement of ammonia and phosphorus to ground water is expected where flow through macropores or sinkholes occurs, for example, in the aquifers of the karst plain. High concentrations of ammonia measured in the till aquifers is attributed to biochemical reduction of nitrate to ammonia, a process that is favored over denitrification under conditions of low oxygen and nitrate-a hypothesis consistent with expected conditions in the till aquifers in the conceptual model.

Agricultural tile drains are expected to have a considerable effect on the water quality of small, agricultural basins. Tile drains are used in nearly all areas of the White River Basin where row crops are grown on (formerly) poorly drained soils, 
although tile drains typically are used more extensively in the relatively flat till plain region than in the other regions that have more relief. Tile drains intercept percolation from saturated soils and intercept seasonally high ground-water tables and rapidly transmit these sources of water to streams. Soil water is expected to have high concentrations of nitrate, and the effect of the tile drains is to reduce nitrate movement to aquifers and to increase nitrate movement to streams. Most tile drains are expected to flow when soils are wet (usually during winter and spring) and to stop flowing when soils are dry (usually during summer and fall). Consequently, tile drainage is expected to increase the nitrate concentration of streamflow during winter and spring to a greater degree than during summer and fall.

In the conceptual model, concentrations of ammonia and phosphorus in the west fork of the White River are dominated by urban point sources, whereas concentrations of ammonia and phosphorus in the east fork are dominated by nonpoint sources. Concentrations of nitrate in the east fork of the White River are dominated by agricultural nonpoint sources. In the west fork of the White River, concentrations of nitrate are dominated by urban point sources during periods of low flow but are dominated by agricultural nonpoint sources during periods of high flow. In this conceptual model, forested land contributes substantially lower amounts of nutrients to surface and ground water than do agricultural or urban land. Annual loads of ammonia and phosphorus in the west fork of the White River are dominated by urban point sources, whereas annual loads in the east fork are dominated by agricultural nonpoint sources. Annual loads of nitrate in both forks of the White River are dominated by agricultural nonpoint sources, but urban point sources of nitrate in the west fork of the White River can be important to annual loads during extended periods of low flow.

Because of the steady input of nutrients from urban point sources in the west fork, algal productivity is expected to be much greater in the west fork than in the east fork, especially during summer low flows. Intense algal productivity during summer low flow may remove dissolved ammonia, nitrate, and orthophosphate from the water column. Similarly, because of incorporation of dissolved nutrients into algal biomass, suspended organic forms of nitrogen and phosphorus may be the dominant forms of these nutrients during summer low flows. Because the largest cities in the basin are in the upstream reach of the west fork, urban runoff and combined-sewer overflows are expected to affect water quality much more in the west fork than in the east fork. Agricultural practices and the quantities of fertilizers and animal manure applied to farm fields are expected to be similar in both forks, although some differences in the upstream reaches of the east and west forks occur. Nutrient concentrations and loads are expected to be more variable in small streams than in rivers, in part because streamflow is more variable in small streams.

Concentrations of nitrate are expected to be highest during winter and spring because abundant rainfall facilitates transport of nitrate through the soil, because nitrate uptake decreases during the dormant season, and because nitrogen-based fertilizers are applied in spring. Concentrations of nitrate are expected to be lowest during late summer and fall because dry conditions inhibit transport and because nitrate uptake by terrestrial and aquatic vegetation increases during the growing season. Concentrations of nitrate are expected to be higher during wet periods following drought than during extended wet periods. During drought, nitrate is expected to accumulate in soils and provide more nitrate for transport during subsequent wet periods.

Ammonia concentrations are expected to be highest in winter at sites on the west fork because cold water temperatures reduce nitrification of ammonia. Phosphorus concentrations are expected to be highest during summer and fall and lowest during winter and spring on the west fork because of dilution of point-source discharges during runoff and because of a lack of dilution during low flow. Phosphorus concentrations are expected to be highest during winter and spring and lowest during summer and fall on the east fork because sedimentassociated phosphorus is greatest during runoff. 


\section{IMPLICATIONS OF THE ASSESSMENT FOR \\ DATA COLLECTION AND ANALYSIS}

The assessment of existing water-quality data (retrospective analysis) provided valuable information for the development of a conceptual model of nutrient concentrations and loads, but additional data are needed to meet the goals of the NAWQA Program. This section identifies additional data needed to describe and interpret current waterquality conditions and trends. These data are discussed in terms of sample locations, sample frequency, and constituents measured.

Most of the surface-water-quality data analyzed in this assessment have been collected from monitoring sites on large rivers; more information is needed on small drainage basins (less than $300 \mathrm{mi}^{2}$ ). To be consistent with the design criteria for the NAWQA Program, the small basins should be in discrete hydrogeomorphic regions to allow assessment of the effects of natural factors on water quality. To the extent possible, the basins should have a single land use to allow assessment of the effects of human factors on water quality. To facilitate load computations and assessment of the relation of water quality to streamflow, all monitoring sites should be at continuous streamflow-gaging stations.

Few wells in this assessment were in the glacial lowland or the bedrock uplands. Many of the wells in the karst plain and the bedrock lowland and plain were restricted to small areas. Wells should be located over the full extent of the regions. Most of the wells in the bedrock lowland and plain were in the northern part of the region. More wells are needed in the southern part where the character of this region is more apparent. More shallow wells are needed to assess the seasonal variations in water quality and the effects of land use on water quality. Wells constructed in nests at different depths are needed to understand the relation of water quality and depth. Wells in recharge areas, along ground-water flow paths, and in discharge areas near streams are needed to understand changes in ground-water quality as water moves through the flow system and to understand ground-water/surface-water interactions.

Surface-water samples are needed to characterize water-quality variations associated with changes in season and streamflow. A monthly sampling frequency is sufficient to describe seasonal fluctuations and general relations to streamflow for larger basins. Sampling that targets storm runoff is needed to measure the effects of nonpoint-source pollution from urban and agricultural areas and to improve load estimates, especially for smaller basins that respond rapidly to precipitation. Frequent river samples collected during the rising and falling stages of storm runoff are needed to determine water-quality changes during runoff and to understand how well a single sample collected during some part of the runoff cycle represents typical water-quality conditions during runoff. Hourly samples collected during 24- to 48-hour periods are needed to understand the effect of algal uptake on nutrient concentrations during summer low flows.

Retrospective data provided little information on short-term temporal variations in ground-water quality. Monthly samples of ground water are needed to understand the factors affecting short time-scale changes in shallow ground-water quality. Daily or more frequent samples are needed to understand ground-water/surface-water interactions. Once short-time scale changes are understood, appropriate sampling frequencies for determining seasonal variations and variations attributed to recharge can be determined.

Additional constituents are needed to better understand the factors affecting nutrients in the White River Basin. Most of the retrospective data lacked information on the amounts of nutrients in organic versus inorganic forms. Information on the amount of nutrients in organic versus inorganic forms is critical to understanding nutrient sources, fates, and the availability of nutrients for algal uptake. Most of the retrospective data were for unfiltered samples. Data also are needed for filtered samples because knowledge of the phase (dissolved in water, adsorbed on sediments, or 
contained in phytoplankton) is critical to understanding nutrient sources, fates, and the availability of nutrients for algal uptake. Samples for concentrations of chlorophyll or algal biomass and species composition would be helpful in understanding the effects of nutrient concentrations on stream ecosystems and the role of algae in nutrient cycling.

River samples should be collected by use of depth- and velocity-integrating samplers at several locations across the stream because surface grab samples from the center of flow typically underestimate suspended-sediment concentrations and the concentrations of nutrients adsorbed on sediments (Feltz and Culbertson, 1972; Martin and others, 1992). Grab samples also may yield biased concentrations of nutrients dissolved in water in cases where mixing in the cross section is not complete (Anderson, 1963; Horowitz and others, 1990; Droppo and Jaskot, 1995; Marron and Blanchard, 1995). Data on organic versus inorganic nutrient forms also are needed for ground-water samples. Ancillary data, such as concentrations of tritium or other constituents to date ground-water age or tracers for ground-water flow, also may be useful in interpreting ground-water quality.

\section{SUMMARY}

This report analyzes and interprets the spatial and temporal patterns of nutrient concentrations and loads in the White River Basin, Indiana, through the use of existing data, and describes and discusses a conceptual model of the factors affecting nutrient concentrations in surface and ground water in the basin. Water-quality data from 23 surface-water-quality monitoring sites operated by the IDEM and streamflow data from 11 USGS streamflow-gaging stations were analyzed to determine recent (1981-90 water years) waterquality conditions, trends, and river loads for ammonia, nitrate, total nitrogen, and total phosphorus.

The White River Basin drains 11,349 square miles of central and south-central Indiana and is divided into two nearly equal subbasins - the East Fork White River and the White River upstream from its confluence with the East Fork (called the "west fork" of the White River by the State's water-management agencies). Nutrient concentrations generally were higher in the west fork than in the east fork because of the much larger volumes of treated municipal sewage, combined-sewer overflows, and urban runoff discharged to the west fork. Concentrations of nutrients, especially ammonia and total phosphorus, were higher downstream from Muncie, Anderson, and Indianapolis than upstream from these cities. Nutrient concentrations decreased downstream from Indianapolis in the White River and in the downstream reach of the East Fork White River because of dilution, nitrification, adsorption to stream-bottom sediments, and uptake by aquatic vegetation.

Seasonal variations in nutrient concentrations and the relations of nutrient concentrations to streamflow depended on the relative contributions of point and nonpoint sources of the nutrients. In general, point sources dominated ammonia and phosphorus concentrations in the more urbanized west fork, and nonpoint sources dominated ammonia and phosphorus concentrations in the more rural east fork.

Total phosphorus increased with increasing streamflow at monitoring sites on the east fork but decreased with increasing streamflow at sites on the west fork. Increasing concentrations with increasing streamflow were consistent with nonpoint sources of phosphorus that wash off the land, whereas decreasing concentrations with increasing streamflow were consistent with dilution of urban point sources of phosphorus. Median concentrations of total phosphorus were highest during summer and fall downstream from urban areas on the west fork because of decreased base flow for dilution of point sources. Median concentrations of total phosphorus were lowest during winter and spring at these urban sites because of increased dilution provided by higher rates of base flow during winter and spring.

Median concentrations of ammonia in the west fork were highest in winter because of reduced nitrification and biological uptake of ammonia during cold temperatures and were 
lowest in summer because of increased nitrification and biological uptake associated with warm temperatures. Median concentrations of ammonia were highest during summer in the east fork, possibly because of runoff containing animal wastes or fertilizers.

Median concentrations of nitrate were highest in winter and spring because of reduced biological uptake and sufficient moisture to transport nitrate from soils to streams. Median concentrations were lowest during summer and fall because of increased biological uptake and decreased transport from soils to streams during dry conditions. Concentrations of nitrate increased with increasing streamflow at 10 of 11 monitoring sites, a pattern consistent with nonpoint sources of nitrate. Concentrations of nitrate decreased with increasing streamflow at a site immediately downstream from Indianapolis. Increasing streamflow diluted urban point sources of nitrate at this site. Spatial and temporal variations in total nitrogen were similar to those for nitrate because nitrate generally composed 65 to 80 percent of the total nitrogen.

Concentrations of ammonia decreased during the 1981-90 water years at two monitoring sites downstream from Indianapolis. Improvements to the Indianapolis wastewater-treatment plants during 1982 were responsible for these beneficial changes in water quality. Concentrations of ammonia, nitrate, and phosphorus increased during the 1981-90 water years at a site immediately upstream from Indianapolis, probably because of the increased discharge of treated sewage from Carmel. Concentrations of total phosphorus increased during the 1981-90 water years at most sites on the White River upstream from Indianapolis, probably because of changes in municipal effluent quality or quantity.

Commercial fertilizer was the largest input of nitrogen and phosphorus in the White River Basin. Inputs of nitrogen and phosphorus from commercial fertilizers were greater in the upstream reaches of the East Fork White River and the White River than in the downstream reaches. Nutrient input from farm-animal wastes were at least 44 percent greater in the upstream reach of the east fork than in the upstream reach of the west fork. Inputs of nitrogen and phosphorus from municipal sewage at and upstream from Indianapolis on the more urbanized west fork were 4 to 10 times those at monitoring sites on the more rural east fork. Atmospheric deposition composed 11 to 19 percent of the total nitrogen input to selected, large drainage basins. Atmospheric deposition of phosphorus was not estimated.

Point sources of nitrogen composed 4 to 28 percent of the nitrogen transported out of selected, large drainage basins by streamflow. Point sources of nitrogen were insufficient to account for all the nitrogen transported by streamflow, which indicates that sources other than municipal sewage and industrial discharges contributed nitrogen to streamflow. Point sources of phosphorus composed 65 to 214 percent of the phosphorus transported out of these drainage basins by streamflow. Point sources composed 188 to 214 percent of the phosphorus transport in the west fork but only 65 to 67 percent in the east fork. Point sources of phosphorus in the west fork were more than sufficient to account for all the phosphorus transported by streamflow, which indicates that plant-uptake and sedimentadsorption processes removed substantial quantities of phosphorus from streamflow or that estimates of phosphorus contributed by point sources (primarily municipal sewage) are too high.

Mean annual nutrient loads near the mouth of the White River Basin were 1,200 tons/yr ammonia; 40,000 tons/yr nitrate; 57,000 tons/yr total nitrogen; and 2,900 tons/yr total phosphorus. Approximately 2 percent of the total nitrogen load was ammonia, approximately 70 percent was nitrate, and approximately 28 percent was organic nitrogen.

Mean annual nutrient loads were expressed in tons per square mile per year [(tons $\left.\left./ \mathrm{mi}^{2}\right) / \mathrm{yr}\right]$ to enable a comparison of loads at monitoring sites with different sized drainage basins. Loads expressed on the basis of unit area are termed "yields." Ammonia yields increased downstream in the upstream reach of the White River, probably because of the cumulative effect of discharges from municipal sewage-treatment 
plants, combined-sewer overflows, and urban runoff in this reach. Ammonia yield was greatest by far at site WR210 [0.64 (tons $\left.\left./ \mathrm{mi}^{2}\right) / \mathrm{yr}\right]$, downstream from Indianapolis and shows the substantial effect of ammonia discharges from Indianapolis. Ammonia yields at monitoring sites unaffected by point sources were approximately 0.10 (tons $\left./ \mathrm{mi}^{2}\right) / \mathrm{yr}$.

The yield of nitrate downstream from Indianapolis [4.9 (tons $\left./ \mathrm{mi}^{2}\right) / \mathrm{yr}$ at site WR210] was similar to the yield upstream from Indianapolis [4.8 (tons $/ \mathrm{mi}^{2}$ )/yr at site WR248], which indicates that nonpoint sources of nitrate dominate mass transport of this nutrient, even at the site most affected by point sources. Nitrate yields at downstream monitoring sites on the White River and East Fork White River were lower [3.6 (tons $\left.\left./ \mathrm{mi}^{2}\right) / \mathrm{yr}\right]$ than those at upstream sites [4.5-5.5 (tons/ $\left.\left.\mathrm{mi}^{2}\right) / \mathrm{yr}\right]$. Lower yields at downstream monitoring sites probably were caused by dilution by streamflow from forested areas in these larger basins. Similar nitrate yields at the downstream sites on the east and west forks also indicate that the effects of urban discharges of nitrate in the upstream reach of the White River were not discernible in the downstream reach, and that nonpoint sources of nitrate mask point sources of nitrate in terms of mass transport in the White River Basin.

Total phosphorus yields in the west fork were greater than those in the east fork because of the greater amount of treated sewage effluent and urban runoff in the west fork. Total phosphorus yield was highest downstream from Indianapolis [0.58 (tons $\left.\left./ \mathrm{mi}^{2}\right) / \mathrm{yr}\right]$ and can be attributed to point-source discharges and urban runoff in Indianapolis. The yield of total phosphorus was higher at the downstream-most site on the west fork $\left[0.30\left(\right.\right.$ tons $\left.\left./ \mathrm{mi}^{2}\right) / \mathrm{yr}\right]$ than at the downstream-most site on the east fork [0.25 (tons $\left.\left./ \mathrm{mi}^{2}\right) / \mathrm{yr}\right]$, which indicates that point sources of phosphorus in the west fork can be discerned over nonpoint sources in terms of mass transport.

Water-quality samples collected from 48 small streams during base flow in March 1992 were used to compare nutrient concentrations among the major hydrogeomorphic regions in the basin. Because the streams were sampled during an extended period of base flow, surface-water samples were expected to approximate the shallow ground-water quality that sustains base flow. Nutrient concentrations were lowest in the bedrock uplands region, probably because of the small amount of agriculture and urbanization and the large amount of forest. Concentrations of nitrite were highest (median $0.04 \mathrm{mg} / \mathrm{L}$ ) in the till plain region, probably because of denitrification in soils and in the buried sand and gravel lenses that are the main shallow aquifers in this region. Concentrations of nitrate also were highest (median $6.4 \mathrm{mg} / \mathrm{L}$ ) in the till plain region, probably because of discharge from tile-drained agricultural fields rather than from seepage from till aquifers composed of buried sand and gravel lenses.

Ground-water-quality data from 101 wells were used to determine the effect of aquifer type, well depth, well type, and season on nutrient concentrations in ground water. Median concentrations of ammonia were highest $(0.25 \mathrm{mg} / \mathrm{L})$ in till aquifers composed of buried sand and gravel lenses, probably because of biochemical reduction of nitrate to ammonia. Concentrations of nitrate in till aquifers were low, probably because till reduced the downward percolation of soil water and because reducing conditions enabled denitrification and biochemical reduction of nitrate to ammonia. Median concentrations of nitrate were highest in karst aquifers, probably because macropores, sinkholes, and other solution features provided a direct connection of surface and ground water through preferential flow paths from the clayey mantle to the karst aquifer. Concentrations of ammonia generally were higher in deep wells, whereas concentrations of nitrate generally were higher in shallow wells. High ammonia concentrations at depth may have been caused by nitrate reduction to ammonia. High concentrations of nitrate in shallow wells probably were caused by the downward percolation of nitrogen-containing soil water from the land surface. 


\section{REFERENCES CITED}

Anderson, P.W., 1963, Variations in the chemical character of the Susquehanna River at Harrisburg, Pennsylvania: U.S. Geological Survey WaterSupply Paper 1779-B, 17 p.

Arihood, L.A., and Glatfelter, D.R., 1991, Method for estimating low-flow characteristics of ungaged streams in Indiana: U.S. Geological Survey Water-Supply Paper 2372, $18 \mathrm{p}$.

Arvin, D.V., 1989, Statistical summary of streamflow data for Indiana: U.S. Geological Survey Open-File Report 89-62, 964 p.

Baker, D.B., 1984, Fluvial transport and processing of sediments and nutrients in large agricultural river basins: U.S. Environmental Protection Agency, EPA-600/S3-83-054, $6 \mathrm{p}$.

Baker, D.B., Krieger, K.A., Richards, R.P., and Kramer, J.W., 1985, Effects of intensive agricultural land use on regional water quality in northwestern Ohio, in U.S. Environmental Protection Agency, Perspectives on nonpoint source pollution: U.S Environmental Protection Agency, Office of Water Regulation and Standards, EPA 440/5-85-001, p. 201-207.

Banaszak, K.J., 1985, Indiana - Ground-water resources, in National water summary 1984. Hydrologic events, selected water-quality trends, and ground-water resources: U.S. Geological Survey Water-Supply Paper 2275, p. 205-210.

1988, Indiana - Ground-water quality, in Moody, D.W., Carr, Jerry, Chase, E.B., and Paulson, R.W., compilers, National water summary 1986 Hydrologic events and ground-water quality: U.S. Geological Survey Water-Supply Paper 2325, p. 245-250.

Brady, N.C., 1974, The nature and properties of soils (8th ed.): New York, Macmillan, $639 \mathrm{p}$.

Brezonik, P.L., 1973, Nitrogen sources and cycling in natural waters: U.S. Environmental Protection Agency, Office of Research and Development, EPA-660/3-73-002, $167 \mathrm{p}$.
Brown, M.P., Rafferty, M.R., and Longabucco, Patricia, undated, Nonpoint source control of phosphorusA watershed evaluation, Volume 3. Phosphorus transport in the west branch of the Delaware River watershed: New York State Department of Environmental Conservation, $112 \mathrm{p}$.

Bushnell, T.M., 1944, The story of Indiana soils: Lafayette, Ind., Purdue University Agricultural Experiment Station Special Circular 1,52 p.

Carter, D.S., Lydy, M.J., and Crawford, C.G., 1995, Water-quality assessment of the White River Basin, Indiana-Analysis of available information on pesticides, 1972-92: U.S. Geological Survey WaterResources Investigations Report 94-4024, 60 p.

City of Indianapolis, [1991?], 1990 census, Indianapolis MSA - A. General demographics, persons, and housing: Indianapolis, Division of Planning, Department of Metropolitan Development, City of Indianapolis.

Cleveland, W.S., 1979, Robust locally weighted regression and smoothing scatterplots: Journal of the American Statistical Association, v. 74, p. 829-36.

Cohn, T.A., DeLong, L.L., Gilroy, E.J., Hirsch, R.M., and Wells, D.K., 1989, Estimating constituent loads: Water Resources Research, v. 25, no. 5, p. 937-942.

Conover, W.J., 1980, Practical nonparametric statistics (2d ed.): New York, John Wiley and Sons, 493 p.

Conover, W.J., and Iman, R.L., 1981, Rank transformation as a bridge between parametric and nonparametric statistics: American Statistician, v. 35, no. 3, p. 124-129.

Crawford, C.G., 1991, Estimation of suspended sediment-rating curves and mean suspendedsediment loads: Journal of Hydrology, v. 129, p. 331-348.

Crawford, C.G., and Mansue, L.J., 1988, Suspendedsediment characteristics of Indiana streams, 1952-84: U.S. Geological Survey Open-File Report 87-527, 79 p. 


\section{REFERENCES CITED—Continued}

Crawford, C.G., and Wangsness, D.J., 1991a, Effects of advanced treatment of municipal wastewater on the White River near Indianapolis, Indiana - Trends in water quality, 1978-86: U.S. Geological Survey Water-Supply Paper 2393, 23 p.

1991b, Effects of advanced wastewater treatment on the quality of White River, Indiana: Water Resources Bulletin, v. 27, no. 5, p. 769-779.

Crumpton, W.G., and Isenhart, T.M., 1987, Nitrogen mass balance in streams receiving secondary effluent-The role of algal assimilation: Journal of the Water Pollution Control Federation, v. 59, no. 9, p. 821-824.

Dempster, A.P., Laird, N.M., and Rubin, D.B., 1977, Maximum likelihood from incomplete data via the EM algorithm: Journal of the Royal Statistical Society, Series B-Methodological, v. 39, p. 1-38.

Droppo, I.G., and Jaskot, Christina, 1995, Impact of river transport characteristics on contaminant sampling error and design: Environmental Science and Technology, v. 29, no. 1, p. 161-170.

Feltz, H.R., and Culbertson, J.K, 1972, Sampling procedures and problems in determining pesticide residues in the hydrologic environment: Pesticides Monitoring Journal, v. 6, no. 3, p. 171-178.

Fenelon, J.M., and Greeman, T.K., 1994, East Fork White River Basin, in Fenelon, J.M., Bobay, K.E., and others, Hydrogeologic atlas of aquifers in Indiana: U.S. Geological Survey Water-Resources Investigations Report 92-4142, p. 135-156.

Fishman, M.J., and Friedman, L.C., eds., 1989, Methods for determination of inorganic substances in water and fluvial sediments: U.S. Geological Survey Techniques of Water-Resources Investigations, book 5, chap. A1, 545 p.

Fowler, K.K., 1992, Description and effects of the 1988 drought on ground-water levels, streamflow, and reservoir levels in Indiana: U.S. Geological Survey Open-File Report 91-4100, 91 p.
Freeze, R.A., and Cherry, J.A., 1979, Groundwater: Englewood Cliffs, N.J., Prentice-Hall, 604 p.

Gilliom, R.J., Alley, W.A., and Gurtz, M.E., 1995, Design of the National Water-Quality Assessment Program-Occurrence and distribution of waterquality conditions: U.S. Geological Survey Circular $1112,33 \mathrm{p}$.

Gilliom, R.J., and Helsel, D.R., 1986, Estimation of distributional parameters for censored trace level water quality data, 1. Estimation techniques: Water Resources Research, v. 22, p. 135-146.

Glatfelter, D.R., Thompson, R.E., and Nell, G.E., 1989, Water resources data-Indiana, water year 1988: U.S. Geological Survey Water-Data Report IN-88-1, $331 \mathrm{p}$.

Goolsby, D.A., and Battaglin, W.A., 1993, Occurrence, distribution, and transport of agricultural chemicals in the surface waters of the Midwestern United States, in Goolsby, D.A., Boyer, L.L., and Mallard, G.E., Selected papers on agricultural chemicals in water resources of the midcontinental United States: U.S. Geological Survey Open-File Report 93-418, p. 1-25.

Governor's Water Resource Study Commission, 1980, The Indiana water resource-Availability, uses, and needs: Indianapolis, Indiana Department of Natural Resources, $508 \mathrm{p}$.

Hager, S.W., and Schemel, L.E., 1992, Sources of nitrogen and phosphorus to northern San Francisco Bay: Estuaries, v. 15 , no. 1 , p. $40-52$.

Hallberg, G.R., and Keeney, D.R., 1993, Nitrate, in Alley, W.M., ed., Regional ground-water quality: New York, Van Nostrand Reinhold, p. 297-322.

Hallberg, G.R., Libra, R.D., and Hoyer, B.E., 1985, Nonpoint source contamination of ground water in karst-carbonate aquifers in Iowa, in U.S. Environmental Protection Agency, Perspectives on nonpoint source pollution: U.S. Environmental Protection Agency, Office of Water Regulation and Standards, EPA 440/5-85-001, p. 109-114. 


\section{REFERENCES CITED—Continued}

Hamilton, P.A., Shedlock, R.J., and Phillips, P.J., 1989, Ground-water-quality assessment of the Delmarva peninsula, Delaware, Maryland, and VirginiaAnalysis of available water-quality data through 1987: U.S. Geological Survey Open-File Report 89-34, $71 \mathrm{p}$.

Hardy, M.A., Leahy, P.P., and Alley, W.M., 1989, Well installation and documentation, and ground-water sampling protocols for the pilot National WaterQuality Assessment Program: U.S. Geological Survey Open-File Report 89-396, 36 p.

Helsel, D.R., and Hirsch, R.M., 1992, Statistical methods in water resources: Amsterdam, Elsevier Science Publishers, $522 \mathrm{p}$.

Hem, J.D., 1985, Study and interpretation of the chemical characteristics of natural water ( $3 \mathrm{~d}$ ed.): U.S. Geological Survey Water-Supply Paper 2254, $263 \mathrm{p}$.

Hickman, R.E., 1984, Loads of suspended sediment and nutrients from local nonpoint sources to the tidal Potomac River and Estuary, Maryland and Virginia, 1979-81 water years: U.S. Geological Survey OpenFile Report 84-860, 82 p.

Hirsch, R.M., Alley, W.M., and Wilber, W.G., 1988, Concepts for a national water-quality assessment program: U.S. Geological Survey Circular 1021, $42 \mathrm{p}$.

Hirsch, R.M., Slack, J.R., and Smith, R.A., 1982, Techniques of trend analysis for monthly water quality data: Water Resources Research, v. 18, no. 1, p. 107-121.

Hoggatt, R.E., 1975, Drainage areas of Indiana streams: [Indianapolis?], U.S. Geological Survey, 231 p.

Hollander, Myles, and Wolfe, D.A., 1973, Nonparametric statistical methods: New York, John Wiley and Sons, $503 \mathrm{p}$.

Hoover, M.E., and Durbin, J.M., 1994, White River Basin, in Fenelon, J.M., Bobay, K.E., and others, Hydrogeologic atlas of aquifers in Indiana: U.S. Geological Survey Water-Resources Investigations Report 92-4142, p. 113-133.
Horowitz, A.J., Rinella, F.A., Lamothe, Paul, Miller, T.L., Edwards, T.K., Roche, R.L., and Rickert, D.A., 1990, Variations in suspended sediment and associated trace element concentrations in selected riverine cross sections: Environmental Science and Technology, v. 24, no. 9 , p. 1313-1320.

Indiana Agricultural Statistics Service, 1988, Indiana agricultural statistics-1987: Indiana Agricultural Statistics Service No. A 88-1, 117 p.

1991, Indiana agricultural statistics-1990:

Indiana Agricultural Statistics Service No. A 91-1, $142 \mathrm{p}$.

1992, Indiana agricultural statistics-1991:

Indiana Agricultural Statistics Service No. A 92-1, $144 \mathrm{p}$.

Indiana Business Research Center and Indiana University School of Business, [1991], Census '90 quick release report, STF 1 \#1, Selected data for counties \& places: Bloomington, Ind., Indiana Business Research Center and Indiana University School of Business.

Indiana Crop and Livestock Reporting Service, 1985, Annual crop and livestock summary-1984: Indiana Crop and Livestock Reporting Service No. A 85-1, 144 p.

Indiana Department of Environmental Management, 1986, Indiana's fixed site water quality monitoring program strategy: Indianapolis, Indiana Department of Environmental Management, Water Quality Surveillance and Standards Branch, 202 p.

1986-91, Indiana water quality, Monitoring site records-Rivers and streams: Indiana Department of Environmental Management, Office of Water Management, published annually.

[1988], Indiana 305(b) report, 1986-87: Indiana Department of Environmental Management, $231 \mathrm{p}$. 


\section{REFERENCES CITED—Continued}

[1990], Indiana 305(b) report, 1988-89:

Indiana Department of Environmental Management, $297 \mathrm{p}$.

1993, Indiana's Confined Feeding Control LawProposed Recommendations for Compliance: Indianapolis, Indiana Department of Environmental Management, Office of Water Management, $14 \mathrm{p}$.

[1994], Indiana 305(b) report, 1992-93: Indiana Department of Environmental Management, $486 \mathrm{p}$.

1995, Indiana environmental rules-Water, 1994 edition: Indianapolis, Indiana Department of Environmental Management, $454 \mathrm{p}$.

Indiana State Board of Health, 1981-85, Water quality monitoring - Rivers and streams: Indiana State Board of Health, Division of Water Pollution Control, published annually.

1982, Division of Water Pollution Control field and laboratory procedures manual: Indianapolis, Indiana State Board of Health, $328 \mathrm{p}$.

Jacques, D.V., and Crawford, C.G., 1991, National Water-Quality Assessment Program-White River Basin: U.S. Geological Survey Open-File Report 91-169, 2 p.

Jaworski, N.A., Groffman, P.M., Keller, A.A., and Prager, J.C., 1992, A watershed nitrogen and phosphorus balance - The upper Potomac River Basin: Estuaries, v. 15, no. 1, p. 83-95.

Johnson, A.H., Bouldin, D.R., Goyette, E.A., and Hedges, A.M., 1976, Phosphorus loss by stream transport from a rural watershed-Quantities, processes, and sources: Journal of Environmental Quality, v. 5, no. 2, p. 148-157.

Kladivko, E.J., Van Scoyoc, G.E., Monke, E.J., Oates, K.M., and Pask, W., 1991, Pesticide and nutrient movement into subsurface tile drains on a silt loam soil in Indiana: Journal of Environmental Quality, v. 20, no. 1, p. 264-270.
Korom, S.F., 1992, Natural denitrification in the saturated zone-A review: Water Resources Research, v. 28 , no. 6, p. 1657-1668.

LaBaugh, J.W., and Winter, T.C., 1984, The impact of uncertainties in hydrologic measurement on phosphorus budgets and empirical models for two Colorado reservoirs: Limnology and Oceanography, v. 29 , no. 2 , p. $322-339$.

Leahy, P.P., and Wilber, W.G., 1991, National WaterQuality Assessment Program: U.S. Geological Survey Open-File Report 91-54, 2 p.

Lee, Y.W., Dahab, M.F., and Bogardi, Istvan, 1995, Nitrate-risk assessment using fuzzy-set approach: Journal of Environmental Engineering, v. 121, no. 3 , p. 245-256.

Likens, G.E., Bormann, F.H., Pierce, R.S., Eaton, J.S., and Johnson, N.M., 1977, Biogeochemistry of a forested ecosystem: New York, Springer-Verlag, $146 \mathrm{p}$.

Lugbill, Jon, 1990, Potomac River basin nutrient inventory: [Washington, D.C.?], Metropolitan Washington Council of Governments Publication no. 90701,150 p., 6 appendices.

Malott, C.A., 1922, The physiography of Indiana, part 2 of Logan, W.N., Cumings, E.R., Malott, C.A., Visher, S.S., Tucker, W.M., and Reeves, J.R., Handbook of Indiana geology: Indianapolis, Indiana Department of Conservation Publication 21, p. 59-256.

Marron, D.C., and Blanchard, S.F., 1995, Surface-waterquality assessment of the upper Illinois River Basin in Illinois, Indiana, and Wisconsin-Cross-sectional and depth variation of water-quality constituents and properties in the upper Illinois River Basin, 1987-88: U.S. Geological Survey Water-Resources Investigations Report 95-4021, 19 p.

Martin, J.D., 1995, Effects of combined-sewer overflows and urban runoff on the water quality of Fall Creek, Indianapolis, Indiana: U.S. Geological Survey Water-Resources Investigations Report 94-4066, 92 p. 


\section{REFERENCES CITED—Continued}

Martin, J.D., and Craig, R.A., 1990, Effects of storm runoff on water quality in the White River and Fall Creek, Indianapolis, Indiana, June through October 1986 and 1987: U.S. Geological Survey Water-Resources Investigations Report 89-4185, $114 \mathrm{p}$.

Martin, G.R., Smoot, J.L., and White, K.D., 1992, A comparison of surface-grab and cross sectionally integrated stream-water-quality sampling methods: Water Environment Research, v. 64, no. 7, p. $866-876$.

McLeod, A.I., Hipel, K.W., and Bodo, B.A., 1991, Trend analysis methodology for water quality time series: Environmetrics, v. 2, no. 2, p. 169-200.

Metcalf \& Eddy, Inc., 1979, Wastewater engineeringTreatment, disposal, reuse ( $2 \mathrm{~d}$ ed.): New York, McGraw-Hill, 920 p.

Meybeck, Michel, 1982, Carbon, nitrogen and phosphorus transport by world rivers: American Journal of Science, v. 282, p. 401-450.

MidWest Plan Service, 1992, Conservation tillage systems and management - Crop residue management with no-till, ridge-till, mulch-till: Ames, Iowa, MidWest Plan Service MWPS-45, 140 p.

National Atmospheric Deposition Program, 1993, NADP/NTN annual data summary-Precipitation chemistry in the United States, 1992: Fort Collins, Colo., Natural Resource Ecology Laboratory, Colorado State University, $480 \mathrm{p}$.

National Research Council, 1978, Nitrates-An environmental assessment: Washington, D.C., National Academy of Sciences, $723 \mathrm{p}$.

Neter, John, Wasserman, William, and Kutner, M.H., 1985, Applied linear statistical models, ( $2 \mathrm{~d}$ ed.): Homewood, Ill., Richard D. Irwin Inc., 1, 117 p.

Owensby, J.R., and Ezell, D.S., 1992, Monthly site normals of temperature, precipitation, and heating and cooling degree days, 1961-90-Indiana: National Oceanic and Atmospheric Administration, Climatography of the United States no. 81, [23] p.
Peden, M.E., Bachman, S.R., Brennan, C.J., Demir, Brigita, James, K.O., Kaiser, B.W., Lockard, J.M., Rothert, J.E., Saur, Jackie, Skowron, L.M., and Slater, M.J., 1986, Development of standard methods for the collection and analysis of precipitation: Champaign, Ill., Illinois State Water Survey Contract Report 381, 375 p.

Peters, N.E., and Bonelli, J.E., 1982, Chemical composition of bulk precipitation in the north-central and northeastern United States, December 1980 through February 1981: U.S. Geological Survey Circular 874, 63 p.

Randall, G.W., Malzer, G.L., and Anderson, B.W., 1993, Nitrate losses to tile drainage as affected by nitrogen fertilization of corn in a corn-soybean rotation, in Agricultural research to protect water qualityProceedings of the conference-Volume 2: Ankeny, Iowa, Soil and Water Conservation Society, p. 683-685.

Ray, A.A., ed., 1982, SAS user's guide-Basics: Cary, N.C., SAS Institute, 923 p.

Ruhe, R.V., and Olson, C.G., 1980, The origin of Terra Rossa in the karst of southern Indiana, reprinted from Field trips 1980, 14th annual meeting, NorthCentral Section, Geological Society of America: Bloomington, Ind., Indiana University, Water Resources Research Center, p. 84-122.

Scanlon, B.R., 1990, Relationships between groundwater contamination and major-ion chemistry in a karst aquifer: Journal of Hydrology, v. 119, p. 271-291.

Schneider, A.F., 1966, Physiography, in Lindsey, A.A., ed., Natural features of Indiana: Indianapolis, Indiana Academy of Science and Indiana State Library, p. 40-56.

Scribner, E.A., Thurman, E.M., Goolsby, D.A., Meyer, M.T., Mills, M.S., and Pomes, M.L., 1993, Reconnaissance data for selected herbicides, two atrazine metabolites, and nitrate in surface water of the midwestern United States, 1989-90: U.S. Geological Survey Open-File Report 93-457, 77 p. 


\section{REFERENCES CITED—Continued}

Shuval, H.I., 1977, Health effects of nitrates in water: U.S. Environmental Protection Agency, Office of Research and Development, EPA-600/1-77-030, $149 \mathrm{p}$.

Sisterson, D.L., 1990, Appendix A, Detailed SOx-S and NOx-N mass budgets for the United States and Canada, in Venkatram, Akula, principal author, Relationships between atmospheric emissions and deposition/air quality: National Acid Precipitation Assessment Program Report 8, [variously paged].

Smith, R.A., Alexander, R.B., and Lanfear, K.J., 1993, Stream water quality in the conterminous United State-Status and trends of selected indicators during the 1980's, in Paulson, R.W., Chase, E.B., Williams, J.S., and Moody, D.W., compilers, National water summary 1990-91-Hydrologic events and stream water quality: U.S. Geological Survey Water-Supply Paper 2400, p. 111-140.

Sommers, L.E., 1985, Chemical equilibria to model volatilization of ammonia from aquatic and soil systems: West Lafayette, Ind., Purdue University, Water Resources Research Center Technical Report 175, 22 p.

Stewart, J.A., and Nell, G.E., 1991, Water resources data - Indiana, water year 1990: U.S. Geological Survey Water Data Report IN-90-1, 340 p.

Thurston, R.V., Russo, R.C., and Emerson, Kenneth, 1979, Aqueous ammonia equilibrium-Tabulation of percent un-ionized ammonia: U.S. Environmental Protection Agency, Office of Research and Development, EPA-600/3-79-091, 428 p.

Ulrich, H.P., 1966, Soils, in Lindsey, A.A., ed., Natural features of Indiana: Indianapolis, Indiana Academy of Science and Indiana State Library, p. 57-90.

U.S. Environmental Protection Agency, 1983, Methods for the chemical analysis of water and wastes: U.S. Environmental Protection Agency, Environmental Monitoring and Support Laboratory, EPA-600/4-79-020, variable pagination.
1986, Quality criteria for water-1986:

U.S. Environmental Protection Agency,

Office of Water Regulations and Standards, EPA-440/5-86-001, 446 p.

U.S. Geological Survey, 1990, Land use and land cover digital data from 1:250,000- and 1:100,000scale maps, Data user guide 4: Reston, Va., U.S. Geological Survey, 25 p.

Vitousek, P.M., 1977, The regulation of elemental concentrations in mountain streams in the northeastern United States: Ecological Monographs, v. 24, no. 1, p. $65-87$.

Voss, R.D., 1992, Nitrogen management, Chapter 13, in Iowa State University Extension Service, 1992-93 private pesticide applicator study guide: Ames, Iowa, Iowa State University Extension Service Report, p. 147-158.

Ward, J.R., and Harr, A.C., eds., 1990, Methods for collection and processing of surface-water and bed-material samples for physical and chemical analyses: U.S. Geological Survey Open-File Report 90-140, $71 \mathrm{p}$.

Wells, E.R., and Krothe, N.C., 1989, Seasonal fluctuations in delta $15 \mathrm{~N}$ of groundwater nitrate in a mantled karst aquifer due to macropore transport of fertilizer-derived nitrate: Journal of Hydrology, v. 112 , no. $1 / 2$, p. 191-201.

Wetzel, R.G., 1975, Limnology: Philadelphia, W.B. Saunders, $743 \mathrm{p}$.

White, W.B., 1993, Analysis of karst aquifers, in Alley, W.M., ed., Regional ground-water quality: New York, Van Nostrand Reinhold, p. 471-489.

Wolynetz, M.S., 1979, Algorithm 139-Maximum likelihood estimation in a linear model with confined and censored data: Applied Statistics, v. 28, p. 195-206. 